\author{
UNIVERSIDADE DE SÃO PAULO \\ ESCOLA DE ENGENHARIA DE SÃO CARLOS \\ DEPARTAMENTO DE ENGENHARIA DE PRODUÇÃO
}

\title{
PLANEJAMENTO E CONTROLE DA PRODUÇÃO
}

NA PEQUENA EMPRESA:

estudo de caso de fatores intervenientes no desempenho de um empreendimento metalúrgico da cidade de São Carlos-SP

José Henrique de Andrade

Dissertação apresentada à Escola de Engenharia de São Carlos da Universidade de São Paulo, como parte dos requisitos para a obtenção do Título de Mestre em Engenharia de Produção.

Orientador:

Prof. Dr. Edmundo Escrivão Filho

São Carlos, setembro de 2007. 
José Henrique de Andrade

\section{PLANEJAMENTO E CONTROLE DA PRODUÇÃO}

NA PEQUENA EMPRESA:

estudo de caso de fatores intervenientes no desempenho de um empreendimento metalúrgico da cidade de São Carlos-SP

Dissertação apresentada à Escola de Engenharia de São Carlos da Universidade de São Paulo, como parte dos requisitos para a obtenção do Título de Mestre em Engenharia de Produção.

Orientador: Prof. Dr. Edmundo Escrivão Filho 


\section{AUTORIZO A REPRODUÇÃO E DIVULGAÇÃO TOTAL OU PARCIAL DESTE TRABALHO, POR QUALQUER MEIO CONVENCIONAL OU ELETRÔNICO, PARA FINS DE ESTUDO E PESQUISA, DESDE QUE CITADA A FONTE.}

Ficha catalográfica preparada pela Seção de Tratamento da Informação do Serviço de Biblioteca - EESC/USP

A553e

Andrade, José Henrique de

Planejamento e controle da produção na pequena empresa: estudo de caso de fatores intervenientes no desempenho de um empreendimento metalúrgico da cidade de São Carlos-SP / orientador Edmundo Escrivão Filho. - - São Carlos, 2007.

Dissertação (Mestrado-Programa de Pós-Graduação em Engenharia de Produção e Área de Concentração em Economia, Organização e Gestão do Conhecimento) - - Escola de Engenharia de São Carlos da Universidade de São Paulo, 2007.

1. Planejamento operacional. 2. Planejamento, programação e controle da produção. 3. Pequenas e médias empresas. 4. Desempenho. I. Título. 
DEDICATÓRIA

Aos meus pais, José Miguel e Adair, pelo exemplo de caráter, honestidade e dedicação incondicional à família.

A todos os meus familiares, meus vínculos eternos com o passado, presente e futuro. 


\section{AGRADECIMENTOS}

A Deus, fonte de luz e sabedoria, por sempre ter iluminado meu caminho para que eu pudesse concluir mais esta etapa na minha vida pessoal e profissional.

Ao professor e amigo Edmundo, pela excelente orientação acadêmica desde a graduação e pelo exemplo de profissionalismo, caráter e alegria no trato com as pessoas.

Á minha família por todo suporte, confiança depositada, amor e carinho demonstrados em todos os anos de minha vida. Em especial ao meu irmão João, companheiro de convivência em São Carlos e pelo apoio incondicional em todos os momentos de minha formação universitária.

Á minha namorada e grande companheira, Daiane, pelo apoio, carinho e compreensão.

Á empresa objeto de estudo e seu dirigente Sr. Claudio, por ter dado espaço para a realização deste trabalho, concomitantemente à atuação profissional na empresa.

Aos colegas do GEOPE e aos companheiros de disciplinas pela convivência e ambiente saudável proporcionados.

Aos professores Hermosilla e Juliana Veiga pelas sugestões e considerações apresentadas no exame de qualificação.

Aos professores e funcionários do departamento de Engenharia de Produção e á Universidade de São Paulo, pela infra-estrutura disponibilizada e condições necessárias para a conclusão deste trabalho.

Meu muito obrigado a todos! 


\section{RESUMO}

ANDRADE, J. H. (2007). Planejamento e controle de produção na pequena empresa: estudo de caso de fatores intervenientes no desempenho de um empreendimento metalúrgico da cidade de São Carlos-SP. 171p. Dissertação (Mestrado) - Escola de Engenharia de São Carlos, Universidade de São Paulo, São Carlos.

O objetivo geral desta pesquisa foi identificar fatores relacionados ao planejamento operacional da produção que intervêm no desempenho de uma pequena empresa metalúrgica. Como objetivos específicos, pretendeu-se: identificar a existência de políticas e práticas de planejamento na empresa, bem como procedimentos de sua formalização; descrever as características e as atividades do planejamento operacional da produção e os fatores intervenientes em seu desempenho; identificar as características organizacionais específicas da pequena empresa que influenciam o funcionamento do planejamento operacional da produção. Diversos trabalhos da literatura destacam uma relação positiva entre as atividades de planejamento e o desempenho empresarial no âmbito das empresas de pequeno porte e isto motiva o estudo deste assunto. A pequena empresa, devido a suas características específicas tais como restrição de recursos (humanos, financeiros e materiais) e limitado poder de negociação diante de fornecedores, concorrentes e clientes, demonstra dificuldades na sua gestão, entre elas para planejar, controlar e programar a produção de modo a obter um bom desempenho. Para atingir o objetivo proposto, foi desenvolvido um estudo de caso em uma empresa metalúrgica de pequeno porte da cidade de São Carlos/SP, sendo o pesquisador um dos integrantes do quadro de funcionários da empresa, na função de supervisor de PCP, somado à revisão bibliográfica a cerca do tema. Isso, possibilitou o confronto entre a teoria e a prática e a obtenção de conclusões a respeito do tema estudado. Como principais resultados observou-se que: o planejamento operacional carece de informações e análises para a tomada de decisão; o desempenho de uma empresa é influenciado por diversos fatores, e não é possível isolar planejamento e desempenho desses demais fatores, foi verificado um ganho de desempenho expressivo registrado entre os anos de 2002 a 2006 na empresa, porém este trabalho não pôde afirmar que as mudanças realizadas e os fatores do planejamento operacional da produção, PCP, foram influentes no desempenho da empresa. O motivo que impossibilita esta afirmação é o fato de que outros fatores não analisados neste trabalho revelaram-se como de maior impacto sobre o desempenho, por exemplo, a ação da concorrência e a indisponibilidade de recursos de curto prazo em caixa.

Palavras-chave: planejamento operacional, planejamento e controle da produção, especificidades da pequena empresa, desempenho. 


\begin{abstract}
ANDRADE, J. H. (2007). Production planning and control in small business: case study of intervening factors in the performance of a metallurgic company in the city of São Carlos-SP. 171p. Master Dissertation - Escola de Engenharia de São Carlos, Universidade de São Paulo, São Carlos.
\end{abstract}

The aim of this research was to identify related factors to the operational production planning that intervene in the performance of a small metallurgic company. As specific purposes, it was intended: to identify the existence of politics and practical planning in the company as well as procedures of its formalizing; to describe the characteristics and activities of the operational production planning and intervenient factors in its performance; to identify specific organizational characteristics of the small business that influence the functioning of the operational production planning. Several researches detach a positive relation between planning activities and enterprise performance in the scope of small businesses, which motivates the study of this subject. The small business, due to its specific characteristics such as restriction of resources (human, financial and material) and its limited negotiation approach over suppliers, competitors and customers, demonstrates difficulties in its management, such as to plan, control and program the production in order to get a good performance. To achieve the established goal, a case study was developed in a small metallurgic company in the city of São Carlos/SP, in which the researcher belongs to the employees board of the company as the supervisor of PPC, added up to a bibliographical review about the subject. This made possible the confrontation between the theory and practice and obtainment of conclusions regarding the subject studied. As main results it was observed that: the operational planning lacks information and analyses for decision making; a company's performance is influenced by many factors and it is not possible to separate planning and performance from these factors, a significant gain of performance was verified between the years 2002 and 2006 in the company, however this work could not assert that the carried through changes and the factors of the operational production planning, PPC, were influential in the performance of the company. The reason why this affirmation is disabled is the fact that other factors not analyzed in this study were brought out as the biggest impact in performance, for example, the action of the competitors and the unavailability of resources of short term in the company.

Keywords: operational planning, production planning and control, small business specificity, performance. 


\section{LISTA DE FIGURAS}

Figura 1: Relação entre planos estratégicos e operacionais ............................................. 26

Figura 2: Relação entre planejamento, ação e controle ....................................................... 28

Figura 3: Relação entre estágios produtivos na abordagem tradicional e na JIT ................. 46

Figura 4: Esboço das atividades e inter-relações do PCP................................................. 53

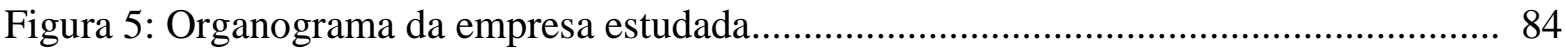

Figura 6: Fatores e eventos que intervem no desempenho da empresa............................... 115 


\section{LISTA DE QUADROS}

Quadro 1: Medidas parciais dos objetivos de desempenho da produção ............................. 35

Quadro 2: Características dos elementos organizacionais relacionados à produção............. 40

Quadro 3: Classificação do porte das empresas segundo o número de funcionários ............ 59

Quadro 4: Classificação do porte das empresas segundo o faturamento bruto anual............ 59

Quadro 5: Funcionários da área administrativa - escolaridade e tempo na empresa ............ 92

Quadro 6: Funcionários da área industrial - escolaridade e tempo na empresa................... 96 


\section{LISTA DE TABELAS}

Tabela 1: Participação empresarial conforme o porte na economia brasileira ..................... 58

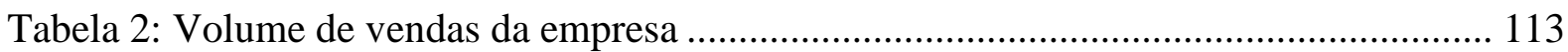




\title{
LISTA DE ABREVIATURAS E SIGLAS
}

\author{
APICS - American Production and Inventory Control Society \\ CAD - Computer Aided Design \\ CNC - Computer Numerical Comand \\ CQ - Controle de Qualidade \\ EESC - Escola de Engenharia de São Carlos \\ ERP - Enterprise Resource Planning
}

GEOPE - Grupo de Estudos Organizacionais da Pequena Empresa

IBGE - Instituto Brasileiro de Geografia e Estatística

JIT - Just in time

MPE - Micro e Pequena Empresa

MRP - Material Requirement Planning

MRPII - Manufacturing Resource Planning

OP - Ordem de Produção

OPT - Optimized Production Technology

PCP - Planejamento e Controle da Produção

SC - Solicitação de Compra

SEADE - Sistema Estadual de Análise de Dados

SEBRAE - Serviço Brasileiro de Apoio às Micro e Pequenas Empresas

SGQ - Sistema de Gestão da Qualidade

USP - Universidade de São Paulo 


\title{
SUMÁRIO
}

\author{
RESUMO \\ ABSTRACT \\ LISTA DE FIGURAS \\ LISTA DE QUADROS \\ LISTA DE ABREVIATURAS E SIGLAS
}

1. INTRODUÇÃO 13

1.1 CONTEXTUALIZAÇÃO DO TEMA E DO PROBLEMA DA PESQUISA ………......13

1.2 CARACTERIZAÇÃO DO TEMA DA PESQUISA …………………………………..... 14

1.3 FORMULAÇÃO DO PROBLEMA DA PESQUISA ....................................................15

1.4 DECLARAÇÃO DOS OBJETIVOS DA PESQUISA................................................. 16

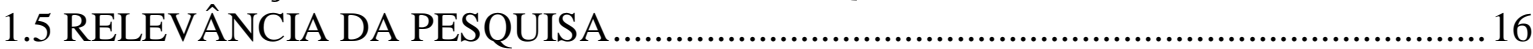

1.6 ESTRUTURA E ORGANIZAÇÃO DO TEXTO …………………………………….... 18

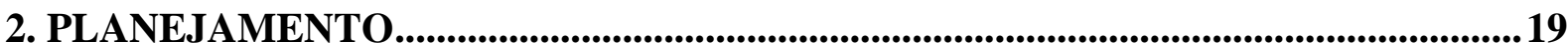

2.1 O CONCEITO DE PLANEJAMENTO .............................................................. 19

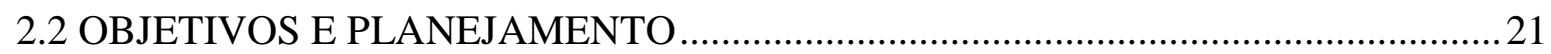

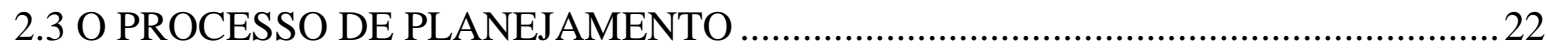

2.4 TIPOS DE PLANOS E HORIZONTES DE PLANEJAMENTO_.................................2

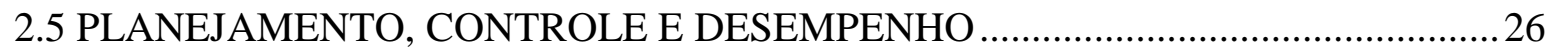

2.6 CRÍTICAS AO PLANEJAMENTO_...........................................................................2 28

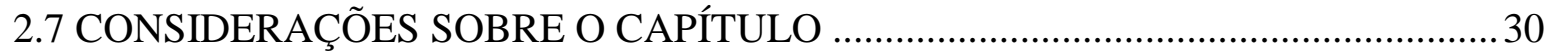

3. PLANEJAMENTO E CONTROLE DA PRODUÇÃO ........................................................32

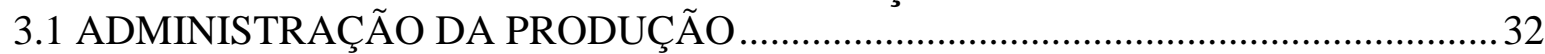

3.2 ATIVIDADES DA ADMINISTRAÇÃO DA PRODUÇÃO..........................................35

3.3 FILOSOFIAS E SISTEMAS DE ADMINISTRAÇÃO DA PRODUÇÃO ………….......38

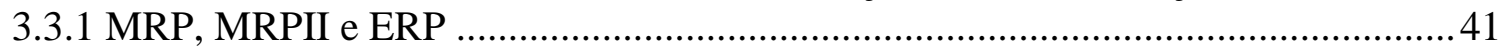

3.3.2 Just-in-time e produção enxuta............................................................................. 44

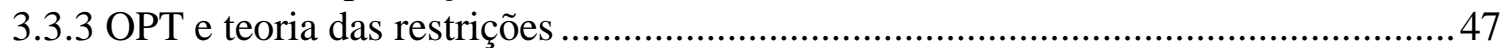

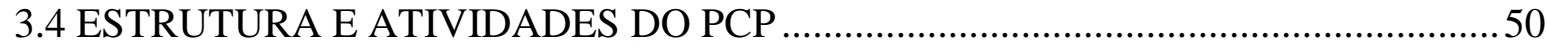

3.5 DIFICULDADES INERENTES ÀS ATIVIDADES DO PCP ……………….............55

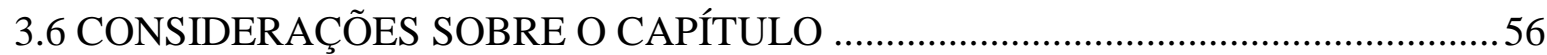

4. ESPECIFICIDADES DA PEQUENA EMPRESA .......................................................57

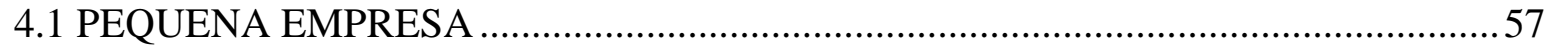

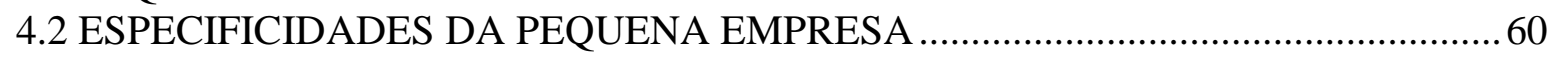

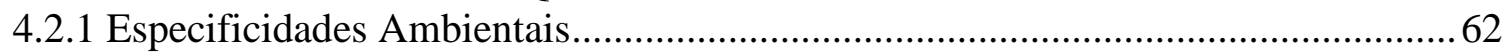

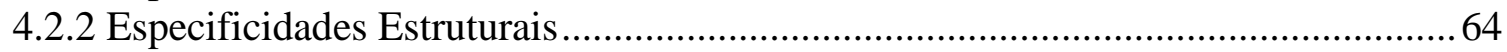

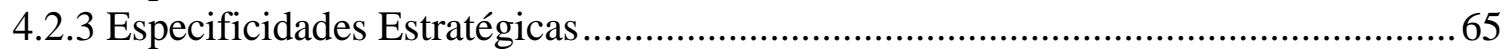

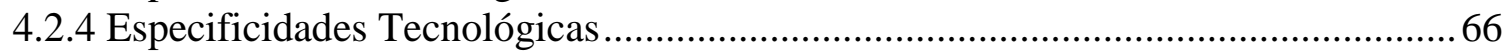

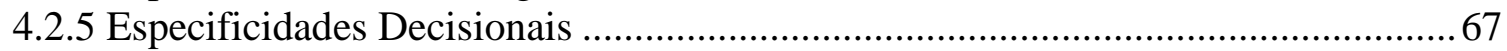

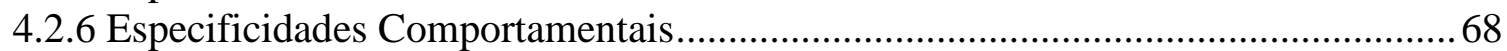

4.3 PLANEJAMENTO NA PEQUENA EMPRESA

4.4 CONSIDERAÇÕES SOBRE O CAPÍTULO .......................................................... 71 


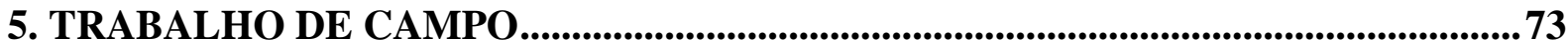

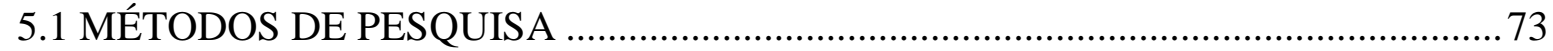

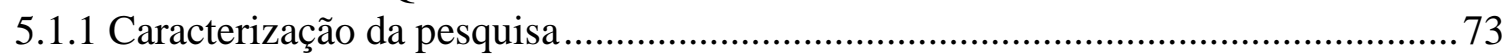

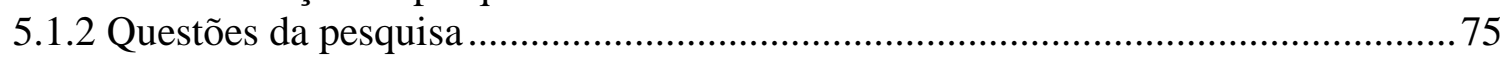

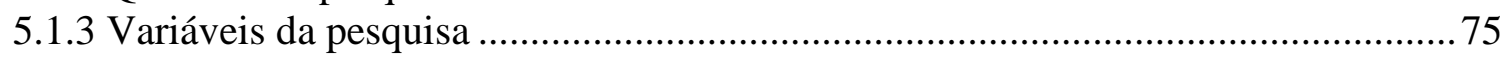

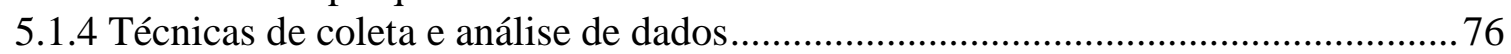

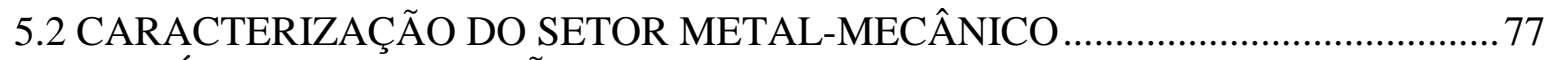

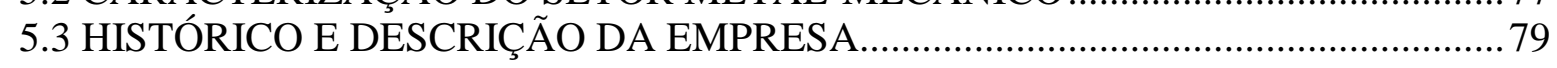

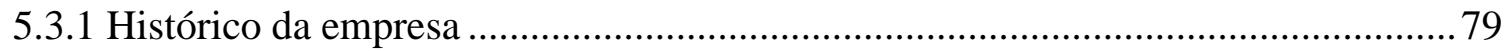

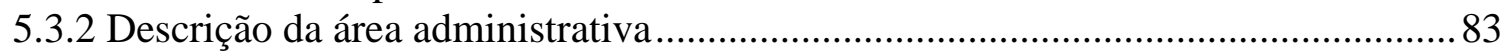

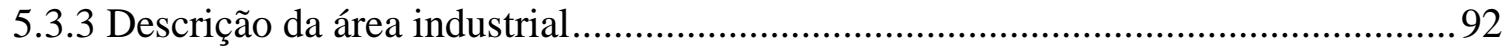

6. APRESENTAÇÃO, ANÁLISE E INTERPRETAÇÃO DOS DADOS ..........................98 6.1 PROCESSOS DE ORGANIZAÇÃO INTERNA E MUDANÇA NA PRODUÇÃO....98

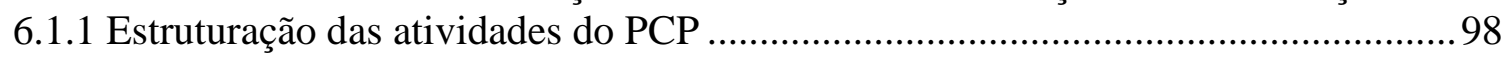

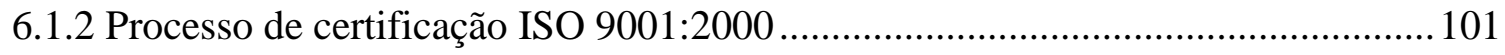

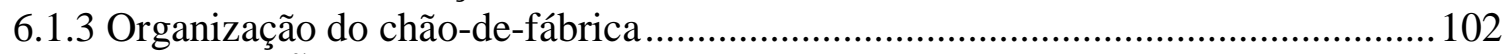

6.2 CONSTATAÇÕES SOBRE AS ESPECIFICIDADES DA PEQUENA EMPRESA . 104

6.3 PLANEJAMENTO ESTRATÉGICO E OPERACIONAL NA EMPRESA ............... 108

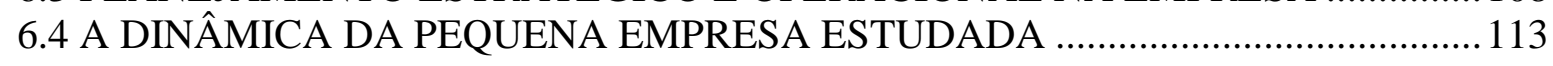

6.5 PLANEJAMENTO, PCP E PEQUENA EMPRESA …............................................. 117

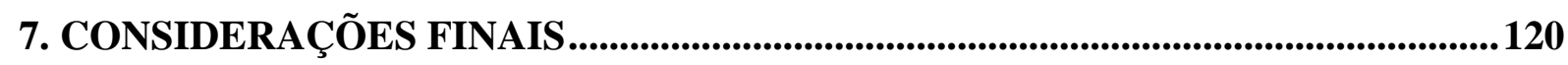

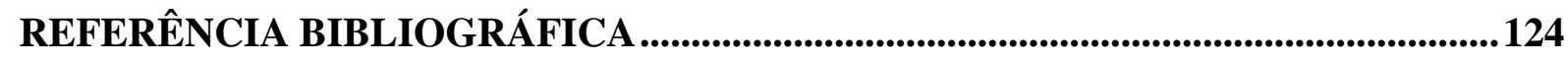

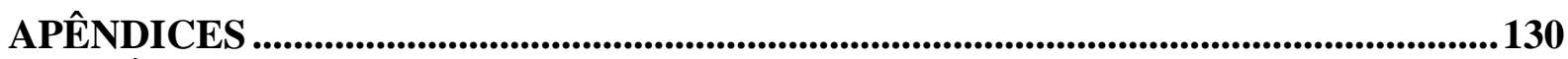

APÊNDICE A - Roteiro de entrevista aplicado no gerente de vendas ............................130

APÊNDICE B - Roteiro de entrevista aplicado no proprietário-dirigente .......................132

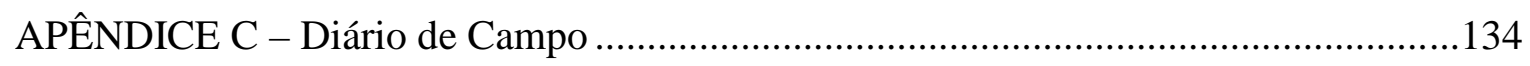




\section{INTRODUÇÃO}

O propósito do capítulo é apresentar o tema, o problema e os objetivos da pesquisa. O tema da pesquisa é o planejamento operacional da produção, representado na literatura pelo PCP, com foco de análise em uma pequena empresa metalúrgica.

\subsection{CONTEXTUALIZAÇÃO DO TEMA E DO PROBLEMA DA PESQUISA}

A pressão competitiva presente no cenário empresarial leva as organizações a buscarem posições competitivas sustentáveis, tendo que responder às demandas de mercado com qualidade, rapidez e confiabilidade a um custo razoável. A razão da maior competitividade é a globalização de mercados e o advento de novas tecnologias (CORRÊA e GIANESI, 1993).

Corrêa e Gianesi (1993) observam que as mudanças ocorridas no panorama competitivo industrial levaram a uma crescente revalorização do papel da manufatura para o atingimento dos objetivos estratégicos das organizações. Essa revalorização possui três causas principais: crescente pressão por competitividade gerada com a queda de importantes barreiras alfandegárias protecionistas e o surgimento de novos concorrentes bastante capacitados; o desenvolvimento de novas tecnologias de processo e gestão, trazendo consigo um enorme potencial competitivo; e um melhor entendimento do papel estratégico que a produção pode e deve ter no atingimento dos objetivos globais da organização.

Pires (2004) observa, levando em conta as tendências mais recentes, que, principalmente nos setores onde o nível de competição é mais acirrado, apenas a excelência nas operações internas das organizações já não é suficiente para garantir o sucesso no 
mercado e, portanto, a competitividade da organização. É preciso considerar, além dos aspectos organizacionais internos, a cadeia produtiva na qual a organização está inserida e os fatores logísticos relacionados como determinantes da sua competitividade. Corroborando esta idéia, Escrivão Filho (2006) salienta que, para o caso das pequenas empresas, é preciso considerar sua forma de inserção na estrutura de mercado e o seu grau de dependência em relação às grandes como fatores que afetam seu desempenho competitivo.

Desta forma, para superarem a crescente pressão competitiva encontrada no cenário empresarial, as organizações precisam ser eficientes na produção de produtos e serviços e eficazes no atingimento dos objetivos organizacionais, passando por um adequado equacionamento das pessoas, tecnologias, informações e demais recursos no seu dia-a-dia, o que se dá por meio das atividades de planejamento.

\subsection{CARACTERIZAÇÃO DO TEMA DA PESQUISA}

Alguns trabalhos (CARVALHO, 2004; ESCRIVÃO FILHO, 2006; SOUZA, 1995; TERENCE, 2002; WELSH e WHITE, 1981) reconhecem que a pequena empresa demanda um processo de gestão diferenciado daquele utilizado nas empresas de maior porte devido às características específicas que as distinguem e às imposições e limitações do ambiente onde atuam. Escrivão Filho (2006) destaca que a pequena empresa é mais bem representada como um grupo social (informal e pessoal) do que por uma organização (formal e impessoal), apresentando desta forma algumas especificidades importantes que devem ser consideradas para que se compreenda sua gestão.

Schermerhorn (1999) destaca que, em tempos dinâmicos, as organizações sofrem pressões vindas de muitas fontes, sejam elas externas, sejam internas à organização. Como pressões externas, o autor cita maior regulamentação governamental, tecnologias cada vez mais complexas, as incertezas da economia global e os custos mutáveis; já como pressões 
internas são citados a busca por maiores níveis de eficiência, novos arranjos na estrutura e no trabalho, maior diversidade na força de trabalho e os desafios gerenciais relacionados. Segundo o autor, o planejamento oferece vantagens importantes em tais circunstâncias, como por exemplo, o aperfeiçoamento do foco e da flexibilidade, da coordenação, do controle e da administração do tempo.

Por outro lado, a função produção nas organizações industriais apresenta um papel fundamental para o cumprimento dos objetivos organizacionais, exigindo, portanto, uma administração consciente e proativa, isso se dá através do planejamento operacional da produção, que é representado na literatura pelo planejamento e controle da produção (PCP).

\subsection{FORMULAÇÃO DO PROBLEMA DA PESQUISA}

Diversos trabalhos da literatura (AMER e BAIN, 1990; BERMAN, GORDON e SUSSMAN, 1997; LYLES et al., 1993; RUE e IBRAHIM, 1998; WIJEWARDENA et al., 2004) apontam os benefícios gerados pela formalização das atividades de planejamento no âmbito das empresas de pequeno porte. Esses autores destacam uma relação positiva entre a formalização das atividades de planejamento e o desempenho empresarial, medido nesses estudos através do crescimento do volume de vendas das empresas.

Os autores destacam que, no caso dos empreendimentos de pequeno porte, prevalece a condição de não realização de atividades formais e sistemáticas. Berman, Gordon e Sussman (1997) e Lyles et al. (1993) apontam como resultado de seus estudos que 74\% e 63\%, respectivamente, das empresas estudadas não realizam atividades formais de planejamento. Porém, será que apenas a formalização ou sistematização das atividades de planejamento proporcionam um bom desempenho empresarial? Será que todo empreendimento de pequeno porte necessita de um planejamento formalizado? Existe um nível de formalização adequado para o planejamento de um empreendimento de pequeno porte? 
Além da não formalização das atividades de planejamento no âmbito das empresas de pequeno porte, aspecto já destacado na literatura, espera-se verificar a existência de outros fatores que intervêm no seu desempenho. Diante desse contexto, o problema da pesquisa concentra-se na seguinte questão:

Quais fatores relacionados ao planejamento operacional da produção intervem no desempenho de uma pequena empresa metalúrgica?

Com o problema apresentado não há a pretensão de se isolar o desempenho da empresa apenas a fatores relacionados ao planejamento operacional da produção, sabe-se de imediato que o desempenho empresarial é grandemente afetado tanto por fatores internos à empresa quanto por fatores externos.

\subsection{DECLARAÇÃO DOS OBJETIVOS DA PESQUISA}

O objetivo geral desta pesquisa é identificar fatores relacionados ao planejamento operacional da produção que intervêm no desempenho de uma pequena empresa metalúrgica.

Como objetivos específicos, pretende-se:

1. identificar a existência de políticas e práticas de planejamento na empresa, bem como procedimentos de sua formalização;

2. descrever as características e as atividades do planejamento operacional da produção e os fatores intervenientes em seu desempenho;

3. identificar as características organizacionais específicas da pequena empresa que influenciam o funcionamento do planejamento operacional da produção.

\subsection{RELEVÂNCIA DA PESQUISA}

As pequenas empresas são extremamente relevantes no contexto socioeconômico mundial, funcionando como um grande amortecedor de crises. Isso pode ser conferido sob 
dois aspectos: o social, pois oferecem muitas oportunidades de emprego e o econômico, através de sua importante participação na geração de riquezas. Além disso, tais empresas contribuem significativamente no ambiente de negócios ao estimularem a competição e a inovação (BORTOLI NETO, 1980; LONGENECKER, MOORE e PETTY, 1997; TERENCE, 2002).

Dados do Sebrae (2005) demonstram que as pequenas empresas, no contexto brasileiro, respondem por cerca de 5,8 milhões de empregos e contribuem com $15,7 \%$ da massa salarial.

Não é tão atual o reconhecimento da importância das pequenas empresas para o contexto socioeconômico. Bortoli Neto (1980) já destacava que as pequenas empresas são essenciais e indispensáveis nas economias desenvolvidas e em desenvolvimento.

Entretanto, no âmbito da pesquisa, é atual a reavaliação do papel das pequenas empresas. Órgãos como o Sebrae, ao realizar estudos e evidenciar as importantes contribuições deste porte de empresa para a economia, assim como suas deficiências, revelam a necessidade de um profundo repensar de suas reais necessidades, principalmente no que diz respeito à sua gestão (SEBRAE, 2003).

Diante desse contexto e da necessidade de avaliar e contribuir para a gestão das empresas de pequeno porte, reconhecendo que este porte de empresa possui características específicas que as diferem das de maior porte, o presente trabalho ganha relevância na medida em que se propõe a somar esforços aos trabalhos que vêm sendo desenvolvidos sobre pequenas empresas, e em especial ao Grupo de Estudos Organizacionais da Pequena Empresa da EESC-USP, contribuindo assim para a construção de conhecimentos alinhados às necessidades dessas empresas. 


\subsection{ESTRUTURA E ORGANIZAÇÃO DO TEXTO}

O texto encontra-se dividido em sete capítulos, sendo neste capítulo, Introdução, apresentada uma contextualização sobre o tema e problema de pesquisa, a caracterização do tema, seguida da formulação do problema, da declaração dos objetivos e sua relevância ao estudar o assunto.

O capítulo 2, Planejamento, apresenta o conceito de planejamento, o papel dos objetivos, o processo pelo qual é realizada a atividade de planejamento, os principais tipos e horizontes de planejamento existentes, aspectos relacionados ao controle e desempenho, assim como algumas críticas apresentadas na literatura.

No capítulo 3, Planejamento e Controle de Produção, são apresentados alguns conceitos sobre administração da produção, os principais sistemas e filosofias de administração da produção, a estrutura e atividades relacionadas ao PCP, seguidas de algumas dificuldades associadas a esta forma de planejamento operacional.

O capítulo 4, Especificidades da Pequena Empresa, apresenta a expressiva participação da pequena empresa no contexto socioeconômico e suas especificidades organizacionais, as quais influenciam sua gestão. Neste capítulo são discutidos, também, alguns aspectos relacionados ao planejamento nessas empresas.

No capítulo 5, Trabalho de Campo, é apresentado o método de pesquisa utilizado para a obtenção e análise dos dados empíricos junto à empresa objeto de estudo e também uma caracterização tanto da pesquisa quanto do setor pesquisado.

O capítulo 6, Apresentação, Análise e Interpretação dos Dados, é reservado para o confronto entre os dados obtidos no trabalho de campo e a revisão bibliográfica.

Por fim, são apresentadas algumas considerações finais sobre a pesquisa seguida das referências bibliográficas e dos apêndices do trabalho, nos quais são apresentados os roteiros de entrevista e o diário de campo. 


\section{PLANEJAMENTO}

Este capítulo tem como propósito apresentar uma revisão da bibliografia destacando o conceito e principais características relacionadas ao tema planejamento. Planejamento tem sido o conceito gerencial fundamental desde o surgimento da "Moderna Administração" com Taylor e Fayol no início do século XX. Embora tenha conhecido uma ascensão em sua importância com o envolvimento da estratégia, também foi com a estratégia que conheceu suas maiores críticas e queda de popularidade. Dividindo espaço com as críticas do racionalismo (autores das relações humanas e comportamentalistas), os defensores do planejamento mantêm considerável espaço nas publicações acadêmicas e na mídia empresarial. Desta forma, ainda que tenha opositores, o planejamento é um tema relevante na administração.

\subsection{O CONCEITO DE PLANEJAMENTO}

O exame da literatura administrativa (ACKOFF, 1981; SCHERMEHORN, 1999; STONER e FREEMAN, 1999; TERENCE, 2002) registra as seguintes características formadoras do conceito de planejamento:

a) é a definição de um futuro desejado e de meios eficazes para alcançá-lo;

b) é algo que se faz antes de agir, ou seja, é tomada de decisão antecipada e faz-se necessário quando a consecução de um estado desejado futuro envolve um conjunto de decisões interdependentes e de ações para que ele ocorra; 
c) significa o desenvolvimento de um programa para realização de objetivos e metas organizacionais, envolvendo a escolha de um curso de ação, a decisão antecipada do que deve ser feito e a determinação de quando e como a ação deve ser realizada;

d) é o processo de estabelecer objetivos e linhas de ação adequadas para alcançá-los.

O conceito de planejamento apresenta dois aspectos bastante destacados na administração: eficácia e eficiência. A eficácia diz respeito à capacidade de fazer a coisa 'certa' - escolha dos fins/objetivos; já a eficiência está relacionada a fazer 'certo' as coisas uso adequado dos recursos (STONER e FREEMAN, 1999).

Conforme Ackoff (1981), a necessidade de planejamento no âmbito empresarial é tão óbvia e tão grande que é difícil para qualquer pessoa se opor a ela, porém é ainda mais difícil tornar tal planejamento útil. O autor ressalta que não fazê-lo bem é um pecado, mas contentarse em fazê-lo pior do que seria possível é imperdoável.

Robbins e Coulter (1998, p.140) são alguns dos autores a observar que o planejamento pode ser classificado como formal ou informal. Segundo eles, no planejamento informal "nada é escrito, e há pouco ou nenhum compartilhamento de objetivos com outras pessoas dentro da organização"; nesta situação o planejamento é genérico e carece de continuidade, o que, salientam os autores, descreve a forma como o planejamento é feito em muitas pequenas empresas. Já no planejamento formal, objetivos específicos são estabelecidos para um intervalo de alguns anos; eles são colocados no papel e ficam à disposição dos membros da organização; por fim, existem programas específicos de ação para alcançar estes objetivos.

Como se pode observar, o conceito de planejamento é estritamente relacionado à definição de objetivos, o que, será tratado na seção seguinte. 


\subsection{OBJETIVOS E PLANEJAMENTO}

Os objetivos são alvos que direcionam a especificação das atividades e os esforços das pessoas; sem eles há desperdício e reais chances de ineficácia nas ações empreendidas (CERTO, 2003). Para Robbins e Coulter (1998), os objetivos são a base do planejamento; referem-se aos resultados desejados pelos indivíduos, grupos ou organizações inteiras, formando os critérios frente aos quais serão comparadas as realizações atuais.

Stoner e Freeman (1999) destacam que os objetivos precisam ser específicos, mensuráveis, realistas e claros e apresentam quatro razões pelas quais eles são importantes no âmbito do planejamento para as organizações:

a) Proporcionam um senso de direção - sem um objetivo, as organizações tendem a andar sem rumo, reagindo às mudanças ambientais sem um sentido claro do que realmente desejam alcançar;

b) Focalizam os esforços - toda organização possui recursos limitados e desta forma a seleção de um objetivo ou um conjunto de objetivos relacionados possibilita que os recursos sejam alocados de maneira consciente de modo a atender as prioridades;

c) Guiam planos e decisões - possibilitam que decisões isoladas estejam alinhadas;

d) Ajudam a avaliar o progresso - os objetivos são parte essencial do controle, pois podem ser encarados como um padrão de desempenho que permite a avaliação do progresso do plano.

As organizações são compostas por muitos subsistemas e grupos diferentes, cada um deles perseguindo uma variedade de objetivos; estes subsistemas e grupos precisam ser coordenados de maneira que não obstruam uns aos outros ao buscarem objetivos isolados. Desta forma, o planejamento aperfeiçoa a coordenação ao estabelecer uma hierarquia de objetivos ou cadeia de objetivos, que é uma série de objetivos encadeados, de tal modo que 
cada objetivo de nível mais alto é apoiado por um ou mais objetivos de nível mais baixo (SCHERMERHORN, 1999).

Nesta mesma linha de pensamento, Chester Barnard observa que "a organização é um sistema social cooperativo, isto é, um sistema onde as pessoas interagem e contribuem para os objetivos comuns". Este autor afirma que as pessoas são racionais e "agem avaliando os benefícios pessoais que alcançarão com o esforço dispendido"; desta forma, cabe à gerência coordenar os esforços pessoais para a realização dos objetivos comuns (ESCRIVÃO FILHO, 1995, p.40).

$\mathrm{Na}$ determinação tradicional de objetivos, são estabelecidas metas no topo da hierarquia e ocorre o seu desdobramento em metas menores para cada nível da organização; nesta perspectiva parte-se do pressuposto de que a alta administração sabe o que é melhor porque só ela pode ter a visão ampla do negócio (ROBBINS e COULTER, 1998).

À medida que esses objetivos, gerados no topo da hierarquia, são disseminados para os níveis inferiores da organização, eles precisam ser desdobrados em objetivos e metas específicas a fim de que haja uma melhor coordenação e acompanhamento das atividades.

Um aspecto bastante salientado na literatura é o processo pelo qual os objetivos e as atividades de planejamento são estabelecidos. Isso é discutido na seção seguinte.

\subsection{O PROCESSO DE PLANEJAMENTO}

A revisão da bibliografia (ROBBINS e COULTER, 1998; SCHERMERHORN, 1999; STEINER, 1979; STONER e FREEMAN, 1999) mostra que a atividade de planejar tem como característica um conjunto de passos que levam à consecução da atividade e a um conjunto de resultados, o que reflete a visão do planejamento em sua configuração formal. 
Para Stoner e Freeman (1999, p.5), “planejar significa que os administradores pensam antecipadamente em seus objetivos e ações, e que seus atos são baseados em algum método, plano ou lógica, e não em palpites”.

Conforme Steiner (1979), planejar com base apenas em intuição e experiência não é suficiente para enfrentar o mundo competitivo dinâmico. $\mathrm{O}$ autor destaca que essas duas características devem ser utilizadas de modo a complementar um processo formal e sistemático de planejamento, a fim de extrair, da intuição e da experiência dos administradores, aspectos relevantes para o planejamento.

Amer e Bain (1990) observam que o processo de planejamento força a empresa a olhar para o futuro das operações do negócio, antecipando-se a possíveis problemas e desenvolvendo soluções para eles. Segundo os autores, planos que são bem desenvolvidos, implementados e controlados, contribuem significativamente para o sucesso empresarial.

Segundo Lyles et al. (1993), planejamento formal é geralmente associado à adoção de um conjunto de passos principais no processo de decisão, destacando também que a formalidade nesse processo tem sido medida associando-se o grau de planejamento manual utilizado versus o uso de ferramentas computadorizadas, a ênfase no desenvolvimento de planos escritos e a existência de procedimentos específicos para formular os planos. Os autores destacam ainda como benefícios do planejamento formal o estímulo da criatividade e de novas formas de se pensar sobre o futuro.

Ao tratarem da dinâmica do processo de planejamento, Corrêa, Gianesi e Caon (2001) destacam que esse processo deve ser contínuo, envolvendo um conjunto de passos que formam um ciclo, tendo como passo inicial o levantamento da situação presente, seguido do desenvolvimento e reconhecimento da visão de futuro, passando pela comparação entre a situação presente e a visão de futuro desejada, pela tomada de decisão gerencial e por fim a execução e acompanhamento do plano. 
Steiner (1979), ao tratar do processo de planejamento estratégico, destaca também um conjunto de passos pertinentes ao processo, que segundo ele englobam a realização de avaliações externas e internas à empresa, do desempenho passado da organização, da situação corrente e de previsões, passando pela formulação do plano, sua implementação e posteriores revisões e avaliações.

Com relação ao conteúdo do plano, Ackoff (1981) sugere que ele deve conter as seguintes partes:

a) Fins: especificação de objetivos e metas;

b) Meios: escolha de políticas, programas, procedimentos e práticas através dos quais se tentará atingir os objetivos;

c) Recursos: determinação dos tipos e quantidades de recursos necessários, como eles devem ser gerados ou obtidos e como eles devem ser alocados às atividades;

d) Forma de implantação: determinação de procedimentos para tomada de decisão e de uma maneira de organizá-los para que o plano possa ser executado;

e) Mecanismos de controle: procedimentos para se detectar e antecipar-se aos possíveis erros contidos no plano ou falhas na sua execução, e para prevenir ou corrigir continuamente esses erros e falhas.

Ackoff (1981, p.2), ao reconhecer que o processo de planejamento constitui-se de um ciclo contínuo, observa que planejamento "não é um ato e sim um processo, sem fim natural ou ponto final", pois não há limite para a quantidade de revisão que se possa fazer de decisões anteriores, pelo fato de que tanto o sistema para o qual se planeja, quanto o seu ambiente mudam e não é possível que todas essas mudanças sejam levadas em consideração. Na mesma perspectiva, Stoner e Freeman (1999) afirmam que a capacidade de re-planejamento é na verdade um fator chave no sucesso de uma organização. 
Robbins e Coulter (1999) advertem, no entanto, que, apesar de algumas pesquisas demonstrarem que organizações usuárias de planejamento formal geralmente apresentarem um desempenho superior, não se pode dizer que essas organizações sempre superam as que não o fazem. Isso, por sua vez, constitui uma das críticas à visão formal do processo de planejamento.

\subsection{TIPOS DE PLANOS E HORIZONTES DE PLANEJAMENTO}

Em função das características e do período de tempo considerados no processo de planejamento, podem-se considerar dois tipos principais de planos: os estratégicos e os operacionais (AMER e BAIN, 1990; SHRADER, MULFORD e BLACKBURN, 1989).

Conforme Amer e Bain (1990) e Shrader, Mulford e Blackbrun (1989), o planejamento estratégico ou de longo prazo envolve um esforço empresarial para monitorar, entender e adaptar-se às mudanças do ambiente a fim de estabelecer e manter uma posição competitiva favorável. Neste tipo de planejamento, são realizadas avaliações do ambiente empresarial, análises internas à empresa, o estabelecimento de objetivos e metas, e a definição de estratégias para que as metas e objetivos sejam atingidos. $\mathrm{O}$ horizonte de tempo considerado pode se estender de 3 a 20 anos, sendo mais comuns horizontes de planejamento variando de 3 a 5 anos.

Já o planejamento operacional, conforme os mesmos autores, está relacionado à definição de um plano detalhado e quantitativo referente às áreas funcionais (produção, finanças, marketing e recursos humanos), especificando como as metas de curto prazo serão atingidas e os procedimentos para administrar as operações diárias.

Ao tratar da ligação entre o planejamento estratégico e operacional, Steiner (1979) observa que ambos estão intimamente ligados, salientando que o estratégico direciona e provê limites para o operacional. 
De acordo com Schermerhorn (1999), as organizações precisam de planos de todas as extensões e, mesmo no nível operacional, faz-se necessário um sentido de direção de longo prazo; do contrário, as pressões dos acontecimentos diários podem criar confusão e desviar a continuidade das ações.

Stoner e Freeman (1999) apontam para uma interdependência entre os planos estratégicos e operacionais, formando uma hierarquia de planos que são ligados por objetivos e metas inter-relacionados, conforme ilustrado na figura 1.

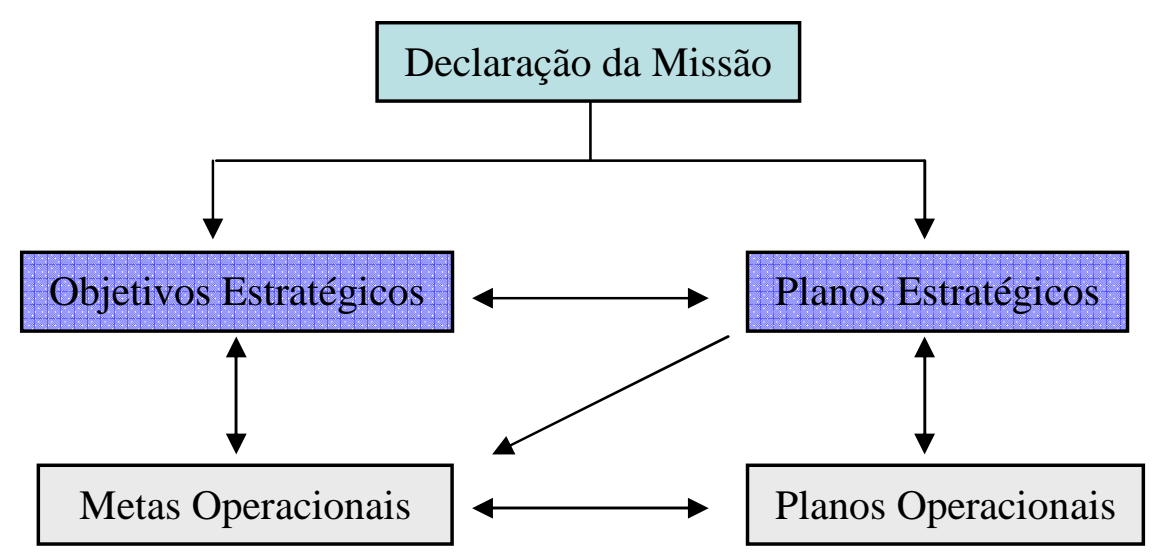

Figura 1: Relação entre planos estratégicos e operacionais Fonte: STONER e FREEMAN (1999)

Segundo Golde (1986), as necessidades de planejamento variam de empresa para empresa e de setor para setor, e o horizonte de planejamento pode ser modificado dependendo da situação vivenciada, atentando-se para o fato de que devem ser usadas técnicas diferentes em função do horizonte considerado. Com a modificação do horizonte de planejamento, problemas diferentes serão encontrados.

\subsection{PLANEJAMENTO, CONTROLE E DESEMPENHO}

Existe na literatura uma extensa discussão a respeito da relação entre planejamento e desempenho. Já no trabalho de Frederick Taylor é possível encontrar a idéia de se relacionar 
planejamento e desempenho. Ao propor métodos e mecanismo para o aumento de produtividade, esse autor destaca, em um dos quatro princípios da Gerência Científica, a importância de se atribuir a um grupo de pessoas na organização, especificamente à direção, a atividade de se planejar o trabalho com antecedência (TAYLOR, 1970).

O controle é exatamente a atividade responsável por monitorar os resultados das ações derivadas do plano. Steiner (1979) aponta que o controle envolve um processo de avaliação de desempenho e de tomada de ações corretivas a medida que são encontrados desvios em relação ao planejado.

De acordo com Slack et al. (1999), há um equilíbrio entre as atividades de planejamento e controle no longo, médio e curto prazo. No longo prazo, a ênfase está mais no planejamento, momento em que a preocupação está voltada para o que se pretende fazer, quais recursos serão necessários e quais são os objetivos a serem atingidos. No médio prazo ocorre um maior detalhamento e parcial desagregação do plano, havendo até re-planejamento se necessário. Já no curto prazo predominam as atividades de controle, pois muitos dos recursos já estão definidos e torna-se difícil fazer neles mudanças de grande escala. Nesse estágio, as atividades correspondem aos ajustes para que as coisas caminhem para o planejado.

Em termos de organização, o planejamento do trabalho pela gerência e o estabelecimento de parâmetros para monitorá-lo, por meio das atividades de controle, representaram um avanço significativo para o acompanhamento de resultados nas organizações, pois o crescimento das empresas condicionou-se à necessidade de divisão do trabalho de supervisão (ESCRIVÃO FILHO, 1995).

Para relacionar planejamento, ação e controle, Schermerhorn (1999, p.96) apresenta a forma pela qual ambos devem trabalhar juntos, como exposto na figura 2. 


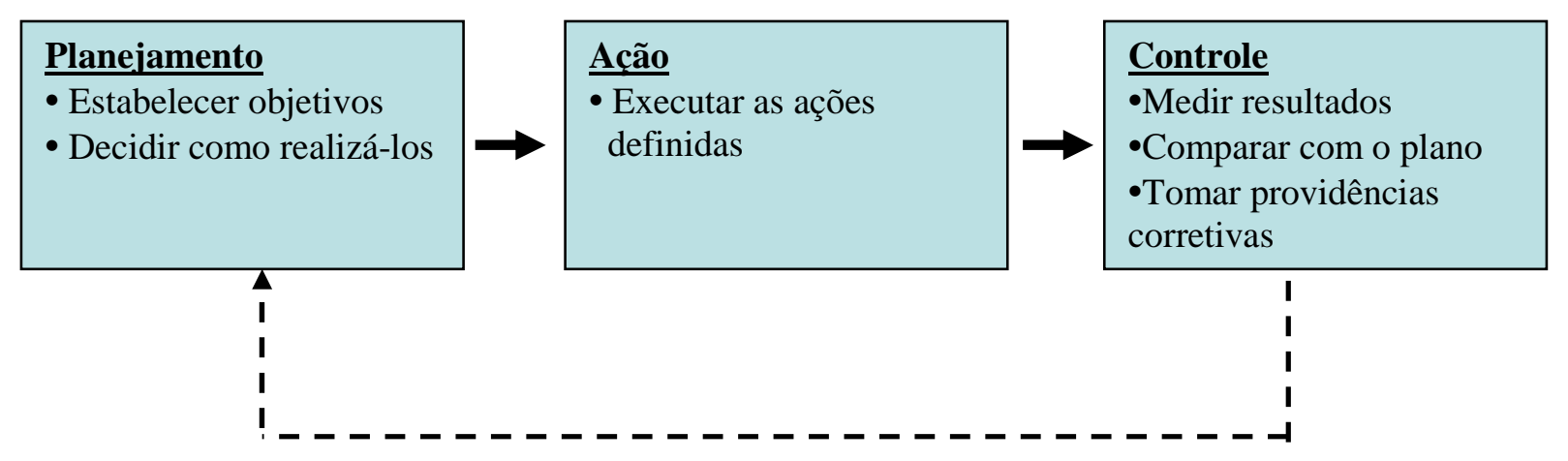

Figura 2: Relação entre planejamento, ação e controle.

Fonte: SCHERMERHORN (1999)

Assim, a atividade de controle é responsável por monitorar o desempenho por meio da medição de resultados e de sua comparação com os objetivos e metas estabelecidos no planejamento.

\subsection{CRÍTICAS AO PLANEJAMENTO}

O planejamento, em sua configuração formal, vem sofrendo diversas críticas na literatura. Mariotto (2003) observa que a maneira tradicional de criação de estratégias por meio de um processo periódico e formal de planejamento estratégico não é mais suficiente para lidar com a intensificada pressão e concorrência que as organizações enfrentam. Nessas circunstâncias, o autor sugere o incentivo à adoção de estratégias emergentes como forma de tornar o processo mais dinâmico, permitindo até maior espaço para iniciativas estratégicas vindas dos níveis mais baixos da organização.

Mintzberg (1994) observa que a chegada do planejamento estratégico no cenário empresarial em meados da década de 60 foi vista pelos líderes empresariais como a 'única maneira' de se desenvolver e implementar estratégias que pudessem incrementar a competitividade de suas unidades de negócio. Entretanto, o autor adverte que os sistemas de planejamento desenvolvidos não produziram os resultados esperados, pois planejamento estratégico não é pensamento estratégico; segundo ele, o primeiro é análise, enquanto o 
segundo é síntese. O autor destaca ainda que os procedimentos passo-a-passo são bons para a produção de planos, no entanto não auxiliam na produção de uma visão, que é o ponto chave do pensamento estratégico.

Mintzberg (2004) apresenta algumas características mais evidentes que impedem a prática bem sucedida do planejamento de uma forma geral, e não só o estratégico, nas organizações. Estas armadilhas segundo ele são disfunções do planejamento e envolvem: a aceitação de que o comprometimento da alta direção promove automaticamente a aceitação do planejamento e de que o planejamento automaticamente gera comprometimento dentro da organização, gerando uma crise de comprometimento causada pela separação entre o planejamento e a execução; a inflexibilidade dos planos como forma de justificar o processo tradicional formal de planejamento, também bastante inflexível, refletindo a visão de que a eficiência está na estabilidade ou na capacidade de análise para prever as condições futuras; a objetividade implícita no processo de planejamento, desconsiderando as mudanças nas condições externas (batalha entre análise e intuição - planejadores versus gerentes de linha); a obsessão pelo controle, sendo a surpresa e a incerteza situações insatisfatórias para o planejamento, desta forma cria-se uma ilusão de controle para validar o processo de planejamento.

Mintzberg (2004) propõe que outras maneiras mais flexíveis de se preparar para o futuro funcionem em conjunto com o planejamento formal de modo a reduzir suas disfunções, entre elas uma linha de ação pautada pelo aprendizado coletivo dentro da organização que possui uma visão emergente do processo de criação de estratégias. Nesta mesma perspectiva, Mariotto (2003) apresenta a estratégia emergente como essencialmente não planejada, no sentido de uma linha de ação que só é percebida como estratégica pela organização à medida que vai se desenrolando ou até mesmo depois que já aconteceu e pode ser tomada como um padrão de ação. 
Mariotto (2003) ressalta, também, a necessidade de interação entre as estratégias intencionadas/deliberadas derivadas do processo tradicional de planejamento, com as estratégias emergentes: as estratégias intencionadas ajudam a dar consistência, continuidade e durabilidade ao comportamento estratégico, enquanto que a estratégia emergente é um mecanismo para dinamizar o processo e torná-lo mais adequado para as condições mutáveis nas quais as organizações encontram-se inseridas.

\subsection{CONSIDERAÇÕES SOBRE O CAPÍTULO}

Conforme a revisão bibliográfica a cerca do tema planejamento, exposta neste capítulo, constata-se que o planejamento pode ser entendido como uma prática administrativa voltada para dotar a ação de direção e sentido, evitando-se a perda de foco (eficácia) e o desperdício de recursos escassos e limitados (eficiência), possibilitando a integração dos esforços organizacionais a fim de atender um objetivo único ou um conjunto de objetivos relacionados (coordenação). Conseqüentemente, a importância dos objetivos está em seu papel como parâmetros que norteiam as ações, formando a base do planejamento e possibilitando o aperfeiçoamento da coordenação através da cadeia de objetivos.

O planejamento constitui-se de um processo no qual são estabelecidos objetivos, definidas ações para que estes sejam alcançados, identificados os recursos necessários e criados mecanismos de controle para identificar a necessidade de ações corretivas para a eficácia do plano.

Destaca-se também a existência de dois tipos principais de planejamento, sendo eles o estratégico e operacional, alterando-se os horizontes de planejamento, as técnicas utilizadas e o foco de análise. O processo de realizar o planejamento pode ser de natureza formal ou informal, salientando-se o fato de que, quando realizado em sua configuração formal, possibilita uma maneira mais sistemática e contínua de se pensar sobre o futuro e transmitir 
objetivos aos demais envolvidos. Diversos trabalhos buscam ainda relacionar planejamento e desempenho; no entanto, apontam para a dificuldade em se afirmar que planejamento formal ou sofisticado garanta um desempenho superior em relação às organizações que não o façam. Nesses trabalhos, o termo sofisticação do planejamento está relacionado à sua formalização.

Destacou-se a atividade de controle como responsável por monitorar o desempenho das ações empreendidas.

As críticas ao processo formal de planejamento revelam a idéia de estratégia emergente. A emersão (criação de estratégias emergentes) como processo de 'dar direção' difere do planejamento, por enfatizar atividades do 'lado de baixo' da pirâmide hierárquica. Tem surgido um movimento de síntese entre os processos de planejamento e emersão. 


\section{PLANEJAMENTO E CONTROLE DA PRODUÇÃO}

Este capítulo tem o propósito de fundamentar a discussão sobre planejamento e controle da produção (PCP), destacando suas principais características e o contexto que permite que esta atividade administrativa se insira nas organizações como forma de planejamento operacional relacionado à produção.

\subsection{ADMINISTRAÇÃO DA PRODUÇÃO}

Na literatura é possível encontrar o uso indistinto dos termos Administração da Produção, Gestão da Produção e, em alguns casos, do termo Planejamento e Controle da Produção, assim como dos termos Produção e Manufatura. Ressaltado o fato de que isso ocorre muitas vezes devido à tradução de maneira diferente de textos na língua inglesa, esta indistinção no uso deles é justificada também por estarem associados a atividades e fins comuns.

Conforme Slack et al. (1999, p.25), “a administração da produção trata da maneira pela qual as organizações produzem bens e serviços”. Segundo esses autores, qualquer operação produz bens e serviços, ou um misto dos dois, e faz isso por um processo de transformação, entendendo-se por transformação o uso de recursos para mudar o estado ou condição de algo de modo a gerar um bem ou serviço a ser consumido.

Gaither e Frazier (2005) usam o termo 'administração da produção e operações' ao tratarem do assunto e o definem como a administração do sistema de produção de uma 
organização, o qual transforma insumos nos produtos e serviços da mesma. Nessa perspectiva, os autores caracterizam sistema de produção como sendo composto por um conjunto de entradas (informações e recursos), um subsistema de transformação e pelas saídas resultantes (produtos/serviços e demais resultados tangíveis e intangíveis).

Corrêa e Gianesi (1993), ao tratarem das mudanças ocorridas no cenário competitivo mundial, destacam a reavaliação do papel da função produção nas organizações para a consecução dos objetivos empresariais e, conseqüentemente, para sua competitividade. Coutinho e Ferraz (1995, p.18) salientam que competitividade pode ser definida "como a capacidade da empresa de formular e implementar estratégias concorrenciais, que lhe permitam conservar, de forma duradoura, uma posição sustentável no mercado”.

Junqueira (2003) observa que a elevação da função produção a um papel estratégico nas organizações teve como subsídio o enorme crescimento econômico japonês ocorrido nas décadas de 60, 70 e 80, crescimento este baseado na melhoria contínua da manufatura e adaptação a um estilo de manufatura de menores lotes focados na customização através da máxima diversificação.

As mudanças ocorridas nas tecnologias de manufatura, assim como o advento de novas tecnologias tanto de chão de fábrica, quanto administrativas, representaram também um incremento significativo nas mudanças ocorridas na administração da produção. A incorporação de novas tecnologias de microeletrônica e de informação nas tecnologias de processo possibilitou a configuração de um novo paradigma de produção em detrimento do paradigma de produção em massa outrora estabelecido. A produção em massa está baseada em grandes lotes de fabricação e pouca variedade de produtos. O uso de máquinas flexíveis controladas por computador tornou os tempos de preparação de máquinas quase desprezíveis possibilitando a fabricação de lotes menores de produtos variados (CORRÊA e GIANESI, 1993). 
Todo este panorama, somado à crescente pressão competitiva advinda com a globalização dos mercados e o acirramento da competição em nível mundial, ressalta a importância de monitorar e aperfeiçoar o desempenho das atividades de produção.

Segundo Slack et al. (1999) e Corrêa e Gianesi (1993), há um conjunto de objetivos de desempenho com os quais se pode avaliar a contribuição da produção para a construção de uma vantagem baseada em produção e, conseqüentemente, a sua eficácia. Esses objetivos de desempenho são:

a) Qualidade - "fazer certo as coisas", proporcionando melhores produtos e serviços ao consumidor;

b) Rapidez - minimizar o tempo de atendimento dos pedidos;

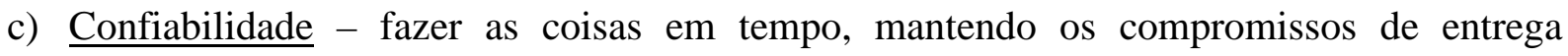
assumidos;

d) $\underline{\text { Flexibilidade }}$ - mudar rapidamente as atividades de produção para enfrentar circunstâncias inesperadas;

e) $\underline{\text { Custo }}$ - fazer as coisas o mais barato possível.

Para Slack et al. (1999), os cinco objetivos de desempenho apresentados são compostos de muitas medidas menores ou parciais, as quais permitem seu acompanhamento e, conseqüentemente, o monitoramento do desempenho da produção e a busca de possíveis melhorias, conforme apresentado no quadro 1.

Segundo Gaither e Frazier (2005, p.24), para se obter um desempenho superior nos negócios, tanto eficácia operacional ("capacidade de executar atividades de operações similares melhor do que os concorrentes"), quanto boa estratégia são fundamentais. Os autores advertem ainda sobre o fato de ser muito difícil para as empresas competirem de maneira bem sucedida a longo prazo baseando-se apenas em eficácia operacional, pois os concorrentes podem imitar rapidamente. Nesse ponto os autores destacam que o desafio para 
administração da produção não é apenas melhorar as operações da empresa para conseguir eficácia operacional, mas também determinar como a eficácia operacional pode ser usada para obter uma vantagem competitiva sustentável.

\begin{tabular}{c|l}
\hline Objetivo de Desempenho & Medidas Parciais Típicas \\
\hline Qualidade & $\begin{array}{l}\text { Número de defeitos por unidade; Nível de reclamação do consumidor; } \\
\text { Nível de refugo; Alegações de garantia; Tempo médio entre falhas; } \\
\text { Escore de satisfação do consumidor }\end{array}$ \\
\hline Velocidade & $\begin{array}{l}\text { Tempo de cotação do consumidor; Lead-time de pedido; Frequiência de } \\
\text { entregas; Tempo de atravessamento real versus teórico; Tempo de ciclo }\end{array}$ \\
\hline Confiabilidade & $\begin{array}{l}\text { Porcentagem de pedidos atendidos com atraso; Atraso médio de pedidos; } \\
\text { Proporção de produtos em estoque; Desvio médio de promessa de chegada; } \\
\text { Aderência à programação }\end{array}$ \\
\hline Flexibilidade & $\begin{array}{l}\text { Tempo necessário para desenvolver novos produtos/serviços; Faixa de } \\
\text { produtos ou serviços; Tempo de set-up; Tamanho médio de lote; Tempo } \\
\text { para aumentar a taxa de atividade; Capacidade média; Capacidade máxima; } \\
\text { Tempo para mudar programações }\end{array}$ \\
\hline Custo & $\begin{array}{l}\text { Tempo mínimo e médio de entrega; Variação contra orçamento; Utilização } \\
\text { de recursos; Produtividade da mão-de-obra; Valor agregado; Eficiência; } \\
\text { Custo por hora de operação }\end{array}$ \\
\hline
\end{tabular}

Quadro 1: Medidas parciais dos objetivos de desempenho da produção

Fonte: SLACK et al. (1999)

A maneira pela qual as organizações produzem bens e serviços, ou seja, seu sistema de produção, é subsidiada por um conjunto de atividades pertinentes à administração da produção, as quais são apresentadas na seção seguinte.

\subsection{ATIVIDADES DA ADMINISTRAÇÃO DA PRODUÇÃO}

A administração da produção encontra-se dividida em atividades, as quais têm o papel de gerenciar e coordenar o sistema de produção. Slack et al. (1999) apresentam estas atividades como sendo relacionadas ao projeto, planejamento e controle e melhoria do sistema produtivo. 
De outro modo, Gaither e Frazier (2005) apresentam as atividades da administração da produção agrupadas em atividades relacionadas a decisões estratégicas, decisões operacionais e decisões quanto ao controle.

Independentemente da forma de agrupá-las, observa-se um consenso em relação ao elenco de atividades, que são (SLACK et al., 1999; GAITHER e FRAZIER, 2005):

a) Projeto de produtos e serviços;

b) Projeto da rede de operações produtivas;

c) Planejamento do layout e fluxo produtivo;

d) Escolha e administração da tecnologia de produção;

e) Administração da cadeia de suprimentos;

f) Planejamento e controle da qualidade;

g) Planejamento e controle da produção.

A atividade de 'Projeto de produtos e serviços' é responsável pela definição das características detalhadas de cada produto ou serviço da organização, momento no qual são definidos e analisados os parâmetros referentes à qualidade, ao custo, à forma de obtenção e ao atendimento dos requisitos do mercado consumidor (GAITHER e FRAZIER, 2005).

O 'Projeto da rede de operações produtivas' está relacionado ao posicionamento do sistema de produção dentro da rede produtiva da qual este sistema faz parte, entendendo a rede como o conjunto de empresas que constituem um determinado setor de negócios, predominantemente clientes e fornecedores. A rede, por sua vez, possibilita a determinação da localização do sistema de produção, da forma de comunicação e do nível de integração com os demais participantes (SLACK et al., 1999).

Já o 'Planejamento do layout e fluxo produtivo', conforme Gaither e Frazier (2005), compreende planejar a localização de todas as máquinas, utilidades, estações de trabalho, áreas de atendimento ao cliente, áreas de armazenamento de materiais entre outros, assim 
como planejar o fluxo de materiais e pessoas nas instalações do sistema produtivo. Destaca-se que essa atividade tem como objetivos: minimizar o custo de processamento, de transporte e de armazenamento dos materiais.

A atividade de 'Escolha e administração da tecnologia de produção' está relacionada à definição, escolha e manutenção das tecnologias de processamento empregadas no chão de fábrica e nos setores de apoio ao sistema de produção. Essa atividade tem como objetivo atender as especificações dos produtos definidas no seu projeto e possibilitar níveis de produtividade adequados (GAITHER e FRAZIER, 2005).

A ‘Administração da cadeia de suprimentos’ corresponde à atividade responsável por gerenciar o fluxo de materiais e informações além das fronteiras da organização, preocupando-se com a gestão de compras e o suprimento de materiais, a gestão da distribuição física e a logística envolvida (SLACK et al., 1999).

O 'Planejamento e controle da qualidade' responsabiliza-se por monitorar e tomar providências corretivas para que sejam atendidas as especificações pertinentes aos produtos e serviços da organização (especificações de projeto ou requisitos declarados pelo cliente), garantindo deste modo a satisfação dos clientes e, conseqüentemente, a manutenção da imagem e a competitividade da organização (SLACK et al., 1999).

O 'Planejamento e controle da produção' consiste na atividade que estabelece o plano operacional para a administração da produção, preocupando-se em gerenciar as atividades da operação produtiva de modo a satisfazer a demanda dos consumidores operando continuamente (SLACK et al., 1999). De outro modo, Burbidge (1981, p.21) expressa que o planejamento e controle da produção "é a função da administração relacionada com o planejamento, direção e controle do suprimento de materiais e das atividades de processo em uma empresa”. 
Destaca-se, por fim, que tais atividades devem possuir um nível de integração adequado, pois seus resultados e objetivos são interdependentes e visam o funcionamento eficaz e eficiente do sistema produtivo.

\subsection{FILOSOFIAS E SISTEMAS DE ADMINISTRAÇÃO DA PRODUÇÃO}

Numa perspectiva histórica, traçada desde o nascimento do capitalismo até os dias atuais, a forma de organizar o trabalho e a produção sofreu mudanças substanciais e, nesse período, muitas filosofias e sistemas foram desenvolvidos e implementados nas organizações para administrar a produção.

No sistema de produção artesanal, os artesãos dominavam toda a tecnologia do produto e do processo de fabricação, ficando sob suas responsabilidades a aquisição da matéria-prima, a coordenação da produção e venda do produto final em pequenas oficinas. As corporações de oficio, associações profissionais de comerciantes ou artesãos, lideradas por mestres artesãos, localizadas nas cidades e comunas medievais, eram organizações fechadas, cujos membros monopolizavam o exercício da profissão ou atividade comercial, estabelecendo regras rígidas para o seu exercício (WREN, 1994).

Singer (1985) destaca que na produção simples de mercadorias, cada mestre trabalhava com um número limitado de oficiais e aprendizes, impedindo o desenvolvimento da divisão técnica do trabalho dentro da oficina. Além disso, as corporações de ofício cuidavam para que a técnica de produção não fosse alterada, evitando-se aumento de produtividade em alguma das oficinas, restringindo o que a corporação denominava como ‘concorrência desleal' aos outros mestres.

A primeira e a segunda revolução industrial, somadas ao crescimento do mercado consumidor, trouxeram consigo a necessidade de uma nova forma de organizar a produção de modo a atender as necessidades emergentes. Nesse contexto surge a produção em massa, 
momento no qual os sistemas de manufatura passaram a ser operados em grandes plantas fabris de alta complexidade de operação e com aumento significativo da capacidade produtiva (MARTINS, 1993). Nesse período, atenção especial foi dada à produção em grandes quantidades de bens padronizados, obtendo-se assim economias de escala e consequiente redução de custos. Exemplo clássico dessa forma de organizar e administrar a produção é dado pela empresa de Henry Ford e a administração científica de Taylor.

Outro momento bastante significativo da forma de organizar e administrar a produção é representado pelo Just in time ou sistema Toyota de Produção desenvolvido no Japão, caracterizado posteriormente também como sistema de produção enxuta. Esse sistema surgiu após a Segunda Guerra Mundial e foi concebido para competir com a indústria automobilística norte-americana, empregando pouco capital e partindo de um conjunto de técnicas, as quais viabilizaram um aumento na frequiência de set-ups e a diminuição da quantidade de máquinas necessárias, além da diminuição do tamanho dos lotes de produção em oposição à produção em massa com equipamentos dedicados e baixa variedade de produtos (MARTINS, 1993).

Martins (1993) observa que toda esta sucessão de momentos resultou em um novo paradigma produtivo mundial baseado na flexibilidade, integração e qualidade. As mudanças ocorridas nas condições competitivas exigem: diminuição no tempo de desenvolvimento de produto; aumento do número de peças a serem fabricadas ou compradas; diminuição no tamanho dos lotes de produção e compra; novas qualificações de engenharia e novos sistemas de informação. Desta forma, as novas dimensões de competição dos sistemas de manufatura são: custo, qualidade, prazo de entrega, flexibilidade e nível de serviço ao consumidor. O quadro 2 sumariza as principais características verificadas nos elementos organizacionais relacionados à produção no momentos históricos salientados. 


\begin{tabular}{|c|c|c|c|}
\hline \multirow{2}{*}{ Elemento } & \multicolumn{3}{|c|}{ Características } \\
\hline & Produção Artesanal & Produção em Massa & Produção Enxuta \\
\hline Produto & $\begin{array}{l}\text { Sob encomenda e } \\
\text { customizado }\end{array}$ & $\begin{array}{l}\text { Padronizado com longo } \\
\text { ciclo de vida }\end{array}$ & $\begin{array}{l}\text { Diversificado e com vida } \\
\text { curta }\end{array}$ \\
\hline Organização & $\begin{array}{l}\text { Poucos níveis } \\
\text { hierárquicos, } \\
\text { descentralizada }\end{array}$ & $\begin{array}{l}\text { Verticalizada e } \\
\text { Burocrática (Intensiva } \\
\text { utilização da divisão do } \\
\text { trabalho) }\end{array}$ & $\begin{array}{l}\text { Poucos níveis } \\
\text { hierárquicos }\end{array}$ \\
\hline Mão-de-Obra & $\begin{array}{l}\text { Altamente qualificada, } \\
\text { domínio de todo } \\
\text { processo produtivo }\end{array}$ & $\begin{array}{l}\text { Especializada numa } \\
\text { tarefa e intercambiável }\end{array}$ & $\begin{array}{l}\text { Altamente qualificada e } \\
\text { multifuncional }\end{array}$ \\
\hline Processo Produtivo & Artesanal & Altamente repetitivo & Repetitivo diversificado \\
\hline Lay-out & Job-shop (flexível) & $\begin{array}{l}\text { Flow-shop na montagem } \\
\text { e nas linhas de fluxo e } \\
\text { Job-shop em setores de } \\
\text { usinagem e conformação }\end{array}$ & Celular \\
\hline Equipamentos & Uso geral & Dedicados & Flexíveis \\
\hline $\begin{array}{l}\text { Volume de } \\
\text { Produção }\end{array}$ & Baixo & Alto, com grandes lotes & $\begin{array}{l}\text { Alto em pequenos lotes } \\
\text { de produção }\end{array}$ \\
\hline $\begin{array}{l}\text { Custos de } \\
\text { Fabricação }\end{array}$ & $\begin{array}{l}\text { Altos, devido à falta de } \\
\text { padronização e baixo } \\
\text { volume }\end{array}$ & $\begin{array}{l}\text { Baixos (economias de } \\
\text { escala e baixos salários) }\end{array}$ & Baixos \\
\hline Qualidade & $\begin{array}{l}\text { Baixa por falta de } \\
\text { padronização }\end{array}$ & $\begin{array}{l}\text { Baixa, utilização da } \\
\text { inspeção de qualidade }\end{array}$ & $\begin{array}{l}\text { Alta, com autocontrole } \\
\text { por todo processo }\end{array}$ \\
\hline $\begin{array}{l}\text { Treinamento da } \\
\text { Mão-de-obra }\end{array}$ & $\begin{array}{l}\text { Longo aprendizado com } \\
\text { os artesãos }\end{array}$ & $\begin{array}{l}\text { Treinamento no próprio } \\
\text { posto de trabalho }\end{array}$ & Intenso \\
\hline Clientes & $\begin{array}{l}\text { Poucos com alto poder } \\
\text { aquisitivo }\end{array}$ & Grandes mercados & Demanda diferenciada \\
\hline
\end{tabular}

Quadro 2: Características dos elementos organizacionais relacionados à produção Fonte: MARTINS (1993)

Três formas de administrar a produção configuraram-se como principais representantes do pensamento administrativo e encontram-se difundidas nas organizações: 1 . os fundamentos e os sistemas MRP, MRP II e ERP; 2. a filosofia Just-in-time e o sistema de produção enxuta e; 3. as técnicas e o software OPT e os fundamentos da teoria das restrições. 
A fim de ressaltar e entender de modo mais claro os conceitos e técnicas tratados em cada uma destas abordagens, estas serão descritas de modo resumido nas próximas seções.

\subsubsection{MRP, MRPII E ERP}

O advento do MRP (Material Requirement Planning) é de importância fundamental no estudo do planejamento da produção; conforme Junqueira (2003), pode-se afirmar que seu surgimento e posterior sistematização revolucionaram o planejamento da produção. Segundo esse autor, a lógica simples e intuitiva do MRP tornou-se aplicável através do uso do computador para organizações que lidam com uma quantidade enorme de itens, significando um grande avanço frente às práticas existentes até então.

Seu atrativo reside não somente no seu conteúdo de sistema de apoio à decisão, mas também em seu caráter de sistema integrador de funções ligadas à manufatura - engenharia, compras e produção (JUNQUEIRA, 2003).

Manetti (2001) apresenta a definição proposta pela APICS (American Production and Inventory Control Society), segundo a qual MRP consiste de um conjunto de técnicas que a partir de dados da estrutura do produto, dados de inventário e do programa mestre de produção, calcula as necessidades de material e recomenda a abertura de ordens de compra e produção, assim como os momentos, de modo a atender os prazos assumidos.

A técnica do MRP simplifica a gestão de materiais de uma empresa, porém, há outras questões importantes a serem tratadas para quem vive em um ambiente de manufatura, tais como capacidade de produção e disponibilidade de recursos humanos e equipamentos que não são tratados pelo MRP.

É nesse contexto que foi criado um novo tipo de sistema, através da inclusão do cálculo de necessidades de capacidade nos sistemas MRP. Conforme Corrêa, Gianesi e Caon (2001), foi com o intuito de deixar claro que se tratava de uma extensão do conceito de MRP 
original, já bastante difundido, que é dado ao novo sistema o nome de Manufacturing Resources Planning, mantendo-se a sigla original então identificada como MRP II. O MRP II diferencia-se do MRP pelo tipo de decisão de planejamento que orienta: enquanto o MRP orienta as decisões de o que, quanto e quando produzir e comprar, o MRP II engloba também as decisões referentes a como produzir, ou seja, com que recursos.

Fundamentados no princípio do cálculo de necessidades, os sistemas MRP e MRP II utilizam uma técnica de gestão que permite o cálculo das quantidades e dos momentos em que são necessários os recursos de manufatura, materiais para o caso do primeiro e materiais, pessoas e equipamentos para o segundo, de forma que sejam cumpridos os programas de entrega de produtos com um mínimo de formação de estoques (CORRÊA e GIANESI, 1993).

Segundo Corrêa, Gianesi e Caon (2001), o conceito de cálculo de necessidade de materiais é simples e conhecido há muito tempo. Baseia-se na idéia de que, se são conhecidos todos componentes de determinado produto e os tempos de obtenção de cada um deles, podese, com base na visão de futuro das necessidades de disponibilidade do produto em questão, calcular os momentos e as quantidades que devem ser obtidas de cada um dos componentes para que não haja falta nem sobra de nenhum deles no suprimento das necessidades dadas pela produção do referido produto.

O MRP II apresenta uma lógica estruturada de planejamento, que prevê uma seqüência hierárquica de cálculos, verificações e decisões, visando chegar a um plano de produção que seja viável, tanto em termos de disponibilidade de materiais como de capacidade produtiva (CORRÊA, GIANESI e CAON, 2001). De acordo com Slack et al. (1999, p.326), "ao longo do tempo, o conceito de MRP desenvolveu-se de um foco na gestão de operações que auxiliava o planejamento e controle das necessidades de materiais, para se tornar, nos anos recentes, um sistema corporativo que apóia o planejamento de todas as necessidades de recursos do negócio". 
Os fornecedores de sistemas MRP II foram gradualmente agregando novos módulos ao sistema, tais como contábil, fiscal, de transportes, financeiro, entre outros, até considerarem suas soluções integradas capazes de suportar as necessidades de informação para todo o empreendimento, dando origem assim aos sistemas ERP (Enterprise Resources Planning).

Os ERP podem ser definidos como sistemas de informação integrados adquiridos na forma de pacotes de software comercial com a finalidade de dar suporte à maioria das operações de uma empresa. Esses sistemas são desenvolvidos por empresas especializadas e abrangem a maioria ou a totalidade dos processos empresariais. No geral, encontram-se divididos em módulos que se comunicam e atualizam uma mesma base de dados central possibilitando que as informações alimentadas em um módulo sejam instantaneamente disponibilizadas para os demais módulos que delas dependam. Apresentam-se como uma alternativa para redução tanto do tempo para o desenvolvimento de um sistema integrado, quanto do custo, pois o sistema já está pronto e testado em diversas outras empresas e subentende-se que o custo desse desenvolvimento foi ou está sendo diluído entre as diversas empresas clientes (SOUZA, 2000).

Como principais características dos sistemas ERP, Souza e Zwicker (1999) destacam: são pacotes comerciais desenvolvidos a partir de modelos padrão de processos baseados nas melhores práticas, integram os sistemas das diversas áreas da empresa, utilizam banco de dados corporativo e atendem a uma ampla gama de funções empresariais.

Esses sistemas, assim como as técnicas e conceitos envolvidos neles representaram um avanço significativo no modo de planejar, controlar e programar a produção, e representam uma forma organizada e sistemática de interligar informações e dados possibilitando ganhos de desempenho na administração da produção, configurando-se como opção bastante viável para as empresas até os dias atuais. 
Conforme Mendes e Escrivão Filho (2002), o objetivo básico ao se adotar um ERP é melhorar os processos de negócios usando tecnologia da informação, e isto, mais do que uma mudança de tecnologia, implica um processo de mudança organizacional.

Entretanto, tais sistemas são considerados como passivos na solução de problemas relacionados à melhoria de desempenho do sistema produtivo, pois são dependentes dos dados alimentados pelos usuários e não englobam técnicas que levam à melhoria contínua da produção. Isso, por sua vez, é ponto forte do Just-in-time e da Produção Enxuta, os quais serão abordados na próxima seção deste trabalho.

\subsubsection{JUST-IN-TIME E PRODUÇÃO ENXUTA}

De acordo com Corrêa e Gianesi (1993), o Just-in-time (JIT) surgiu no Japão em meados da década de 1970, sendo sua idéia básica e seu desenvolvimento creditados à Toyota Motor Company e por isso também conhecido como Sistema Toyota de Produção. Segundo esses autores, o JIT é muito mais que uma técnica ou um conjunto de técnicas para administrar a produção, sendo considerado como uma completa filosofia, incluindo aspectos de administração de materiais, gestão da qualidade, arranjo físico, projeto do produto, organização do trabalho e gestão de recursos humanos.

Os conceitos do modelo JIT foram expandidos para o mundo ocidental e posteriormente deram origem à chamada produção enxuta ou lean manufacturing, que, segundo Castro (2005), trata de uma estrutura conceitual trazida da experiência das empresas japonesas e detalhada no livro ‘A máquina que mudou o mundo' de Womack, Jones e Roos (1992).

A filosofia do JIT é produzir o que é necessário, na quantidade necessária e no momento necessário, evitando-se o desperdício. Isso envolve o desenvolvimento de células de produção como forma de otimizar o fluxo produtivo, a existência de funcionários 
multifuncionais, parcerias com fornecedores e integração do consumidor no sistema de manufatura como forma de evitar flutuações bruscas de demanda (MARTINS, 1993). Além de técnicas para simplificação do projeto do produto como forma de facilitar sua fabricação.

O sistema JIT tem como objetivo central a melhoria contínua do processo produtivo. A perseguição desse objetivo ocorre por meio da redução de estoques, os quais tendem a camuflar problemas e evitar descontinuidade do processo produtivo. Com a redução dos níveis de estoque, os problemas começam a ser expostos e resolvidos de modo a aumentar a confiabilidade do sistema produtivo passando pela melhoria dos índices de qualidade, maior confiabilidade dos equipamentos e fornecedores, maior flexibilidade de resposta à demanda e redução dos tempos de preparação de máquinas (CORRÊA e GIANESI, 1993).

Slack et al. (1999) destacam que, na abordagem tradicional de administração da produção, os estoques garantem uma independência dos processos produtivos em relação aos seus estágios vizinhos, assegurando que cada estágio opere de maneira ininterrupta e, conseqüentemente, eficiente à custa de um alto capital empatado. Já na abordagem JIT, com a eliminação ou redução brusca dos níveis de estoque, os estágios produtivos são dependentes, pois os problemas ocasionados em cada um deles têm impacto direto nos estágios produtivos seguintes e, conseqüentemente, na eficiência do sistema. Isso, torna os problemas mais evidentes e obriga uma gestão no sentido da resolução de problemas. Os autores ilustram esta diferença sobre a independência ou dependência dos estágios com a figura 3.

Desta forma, enquanto na abordagem tradicional a produção é empurrada pelos estágios anteriores para os estágios seguintes com a formação de estoques intermediários, na abordagem JIT a produção é puxada pelos estágios seguintes à medida que surgem as necessidades. 
(a) Abordagem Tradicional

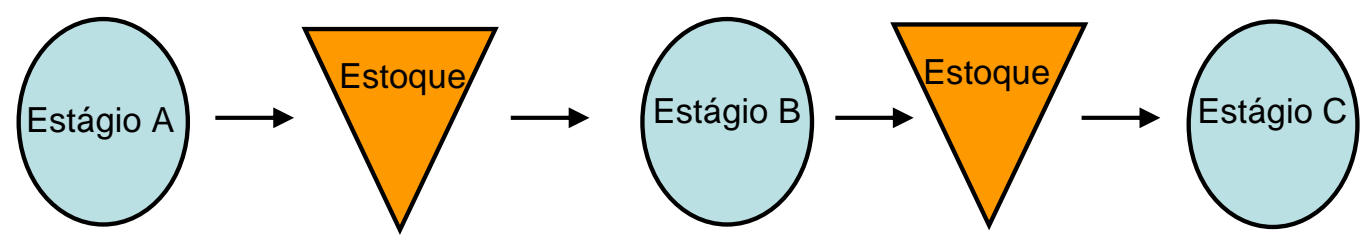

(b) Abordagem JIT

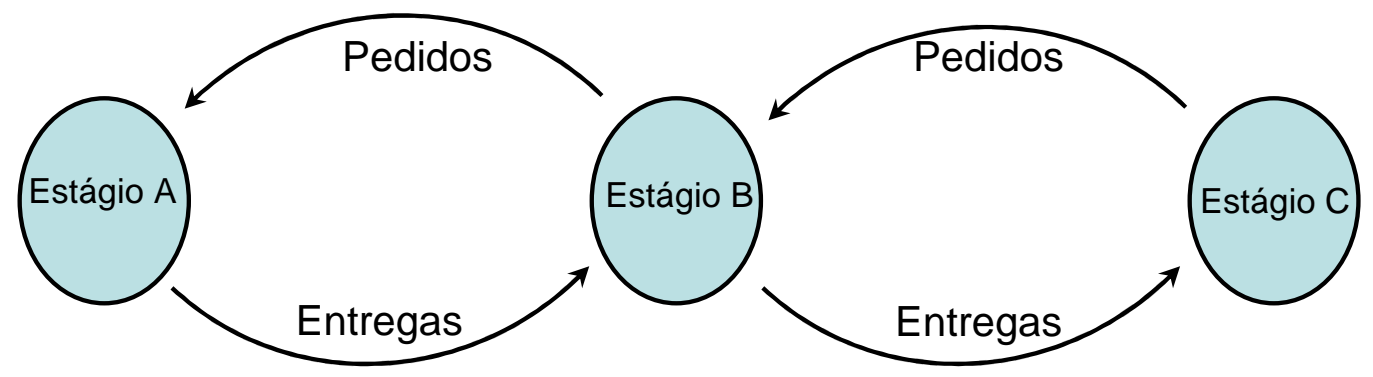

Figura 3: Relação entre os estágios produtivos na abordagem tradicional e na JIT.

Fonte: SLACK et al. (1999)

Conforme Moura e Banzato (1994), JIT é mais do que a redução de inventário, é na verdade a organização total do processo de produção, caracterizado como um enfoque de análise de problemas e de contínuo melhoramento operacional, a curto e longo prazo. Segundo os mesmos autores, produção JIT não é simplesmente uma questão de repassar o inventário para o fornecedor, mas sim um sistema abrangente para administrar e direcionar as operações totais.

De acordo com Slack et al. (1999), o ponto chave do JIT é uma coleção de ferramentas e técnicas, as quais representam os meios para eliminação do desperdício. Exemplos destas são:

a) Técnicas para aprimoramento do projeto do produto, a fim de reduzir o número de componentes e submontagens, além de possibilitar o melhor uso de materiais e proporcionar melhores métodos de trabalho; 
b) Técnicas para mudanças no arranjo físico de modo a permitir um fluxo contínuo de materiais e minimizar atividades que não agregam valor, transporte de materiais, por exemplo;

c) Manutenção produtiva total como forma de eliminar variabilidade em processo devido à quebra de máquinas;

d) Ferramentas e técnicas para a redução dos tempos de set up;

e) Controle visual no processo de fabricação, permitindo que todas as medidas de desempenho e controles sejam vistos e compreendidos por todos os funcionários, como por exemplo, kanbans para o acionamento da produção.

\subsubsection{OPT E TEORIA DAS RESTRIÇÕES}

De acordo com Corrêa e Gianesi (1993), OPT é a sigla para Optimized Production Technology, uma técnica de gestão da produção baseada no uso de um software, desenvolvida por um grupo de pesquisadores israelenses, do qual fazia parte o físico Eliyahu Goldratt, que acabou por ser o principal divulgador dos princípios desta técnica.

Apesar de o nome pelo qual a técnica ficou conhecida sugerir que se trate de um método otimizante ('Tecnologia de Produção Otimizada'), OPT não é uma técnica otimizante no sentido científico do termo, pois nada garante que por sua aplicação sejam atingidas soluções ótimas, já que a técnica é baseada em uma série de procedimentos heurísticos, muitos dos quais os proprietários dos direitos de exploração do sistema nem mesmo tornaram públicos (Corrêa e Gianesi, 1993).

Na abordagem OPT, defende-se que o objetivo básico de uma empresa é ganhar dinheiro e, para isso, o fluxo de manufatura deve ser o maior possível, e o estoque e as despesas operacionais os menores possíveis (CASTRO, 2005; CORRÊA e GIANESI, 1993). Porém, na abordagem OPT esses três termos (fluxo, estoque e despesas operacionais), 
recebem significado diferenciado em relação ao usual, os quais são (CORRÊA e GIANESI, 1993; JUNQUEIRA, 2003; VOLLMANN et al., 1997):

a) Fluxo ou ganho (throughput): é a taxa segundo a qual o sistema gera dinheiro através da venda de seus produtos. Diferencia-se da visão tradicional pelo fato de considerar como fluxo apenas os produtos que estão vendidos; aqueles não vendidos são considerados ainda como estoque e, desta forma busca-se, maximizar o ganho e não simplesmente a produção;

b) Estoque ou Inventário (inventory): trata-se do dinheiro empregado pela empresa nos bens que pretende vender; refere-se ao valor das matérias-primas envolvidas;

c) Despesas Operacionais (operating expenses): todo dinheiro que o sistema gasta para transformar estoque em fluxo/ganho.

Os conceitos básicos que formam a base do OPT e foram popularizados pelo livro 'A Meta' tomaram forma como pensamento sistêmico, ganhando corpo no que foi batizado como ‘Teoria das Restrições', onde se combina a aplicação de conceitos matemáticos e heurísticos a uma série de preceitos que já haviam aparecido sob a filosofia Just in time (JUNQUEIRA, 2003).

Segundo Vollmann et al. (1997) e Corrêa e Gianesi (1993), os princípios básicos envolvidos no método de programação da produção da Teoria das Restrições e dos sistemas OPT são os seguintes:

a) Balancear o fluxo e não a capacidade - na abordagem tradicional buscava-se balancear a capacidade do sistema produtivo e então tentar estabelecer um fluxo de materiais suave e, se possível, contínuo. Já na abordagem OPT busca-se, em função da demanda, balancear o fluxo de materiais a partir da identificação dos recursos gargalos que limitarão o sistema; 
b) As restrições (gargalos) determinam o nível de utilização dos centros produtivos nãogargalos - o nível de utilização de um centro produtivo não-gargalo é ditado pela restrição do sistema e não pela disponibilidade de seus próprios recursos;

c) Utilização e ativação de um recurso não são sinônimos - utilizar um recurso quando sua produção não pode ser absorvida por um gargalo pode significar perda com a formação de estoques desnecessários; desta forma um recurso não-gargalo pode ser ativado abaixo de sua capacidade de utilização;

d) Uma hora ganha num recurso gargalo é uma hora ganha para o sistema todo - como os gargalos são as restrições que limitam o sistema, ganhos neles refletem no sistema todo;

e) Uma hora ganha num recurso não-gargalo não é nada - como o nível de utilização dos recursos não-gargalos é dado em função dos gargalos, ganhos neles não refletem em ganhos para o sistema;

f) Os gargalos não só determinam o fluxo do sistema, mas também definem seus estoques;

g) Os lotes de transferência (tamanho dos lotes que serão transferidos para as próximas operações) deveriam ser variáveis, ou seja, não necessariamente iguais aos lotes de produção;

h) O lote de processamento deve ser variável e não fixo - atendimento apenas das necessidades imediatas, como no JIT;

i) A programação da produção deveria ser estabelecida examinando-se simultaneamente todas as restrições do sistema produtivo - desta forma lead times são resultados da programação e não podem ser preestabelecidos.

Para Junqueira (2003), pode-se dizer que a Teoria das Restrições se divide hoje em três grandes grupos de atuação: 1. os diagramas de causa-e-efeito, denominados de Processos de Raciocínio com suas cinco ferramentas fundamentais (árvore da realidade atual, diagrama de dispersão de nuvem, árvore da realidade futura, árvore de pré-requisitos e árvore de 
transição); 2. o uso das definições de ganho, inventário e despesas operacionais como norteadores para tomada de decisões; 3. o uso de seus aplicativos em gerenciamento de distribuição, marketing, gerenciamento de projetos, o método tambor-pulmão-corda entre outros.

Por fim, destaca-se que algumas críticas são feitas a essa abordagem de administração da produção, como, por exemplo, o OPT procura compatibilizar na sua função objetivo, questões tidas como antagônicas, tais como minimizar custos e maximizar o desempenho das entregas (VOLLMANN et al., 1997).

\subsection{ESTRUTURA E ATIVIDADES DO PCP}

De acordo com Zaccarelli (1986, p.1), a atividade de planejamento e controle da produção (PCP) "consiste essencialmente em um conjunto de funções inter-relacionadas que objetivam comandar o processo produtivo e coordená-lo com os demais setores administrativos da empresa".

Conforme Vollmann et al. (1997), o planejamento e controle de produção provê informações para a administração eficiente do fluxo de materiais, para a efetiva utilização das pessoas e equipamentos disponíveis, para a coordenação das atividades internas com a dos fornecedores externos e para uma comunicação efetiva entre as necessidades do mercado consumidor e o sistema produtivo.

Observa-se que, independentemente do sistema produtivo, da tecnologia empregada no processo e da forma empregada para administrar a produção, existem algumas atividades

que são inerentes à realização do PCP, dentre elas (JUNQUEIRA, 2003; RESENDE e SACOMANO, 2000; VOLLMANN et al., 1997):

a) Processo de previsão de vendas/gestão da carteira de pedidos: consiste da atividade do PCP, que faz a interface com o setor de vendas da organização, a partir da qual são 
gerados os dados a respeito do que produzir e em que quantidades, assim como o seu prazo de conclusão;

b) Planejamento agregado de produção: atividade responsável pelo estabelecimento dos níveis gerais de produção e capacidade, baseado em informações agregadas sobre as necessidades referentes à produção de famílias ou grupos de produtos, a partir da qual é possível avaliar a necessidade de novos investimentos em capacidade no médio e longo prazo;

c) Planejamento mestre de produção: consiste da atividade que define um referencial básico para a produção, estabelecendo quando e em que quantidade cada produto deverá ser produzido dentro de um determinado horizonte de planejamento. Diferentemente do planejamento agregado o plano mestre considera a produção em termos de produtos específicos e não de modo agregado (famílias de produtos);

d) Planejamento das necessidades de materiais: refere-se ao planejamento dos materiais necessários para atender o programa de produção estabelecido e tem como fonte de informação a lista de materiais gerada a partir das necessidades de produtos finais e a posição dos estoques;

e) Controle de estoques: atividade responsável pelo controle físico e quantitativo dos itens fabricados, comprados e utilizados pela organização para a fabricação de seus produtos e para a prestação de serviços;

f) Programação da produção: consiste em definir a carga dos centros de trabalho e os momentos nos quais eles devem ser executados, a fim de cumprir os prazos e programas de entrega assumidos;

g) Planejamento e controle da capacidade: atividade que define os níveis máximos de capacidade do sistema de produção como um todo, assim como dos centros de trabalho 
individuais, avaliando, no decorrer do tempo, a necessidade de ações para adequar o sistema às demandas impostas;

h) Controle da produção: refere-se à atividade responsável por monitorar as operações de produção e tomar decisões a fim de que os objetivos definidos na etapa de planejamento sejam cumpridos (mudanças de prioridades, necessidade de horas extras etc).

Essas atividades constituem a essência do PCP e encontram-se agrupadas em três macroatividades principais: planejamento, controle e programação.

a) Planejamento tem como objetivo a construção de um plano para a produção; é uma formalização do que se pretende que aconteça em determinado momento no futuro, este plano é baseado em expectativas, as quais podem não se realizar por motivos diversos, dentre eles: os clientes podem mudar de idéia em relação aos prazos e quantidades, os fornecedores podem falhar na entrega, máquinas podem quebrar, funcionários faltarem entre outros (Slack et al., 1999);

b) O controle é o processo de lidar com as variáveis que podem impedir que o plano de produção seja executado, são os ajustes necessários para que ele possa ser levado adiante de modo a atingir os objetivos estabelecidos (SLACK et al., 1999), envolvendo também as atividades de acompanhamento para que se mantenha o sistema de produção dentro de padrões e metas pré-estabelecidos (como, níveis de refugo e retrabalho);

c) A programação consiste da determinação de quando e onde cada operação necessária para a fabricação dos produtos estabelecidos no planejamento deve ser executada (RESENDE e SACOMANO, 2000).

Destaca-se que, na realização dessas atividades, existe uma seqüência de tomada de decisões, formando uma estrutura hierárquica de decisões, as quais, na maioria das vezes, encontram-se interligadas e são inter-relacionadas a outras áreas da organização. Um exemplo 
de esboço da estrutura geral das atividades relacionadas ao PCP e de seu inter-relacionamento com outras áreas organizacionais é apresentado na figura 4.

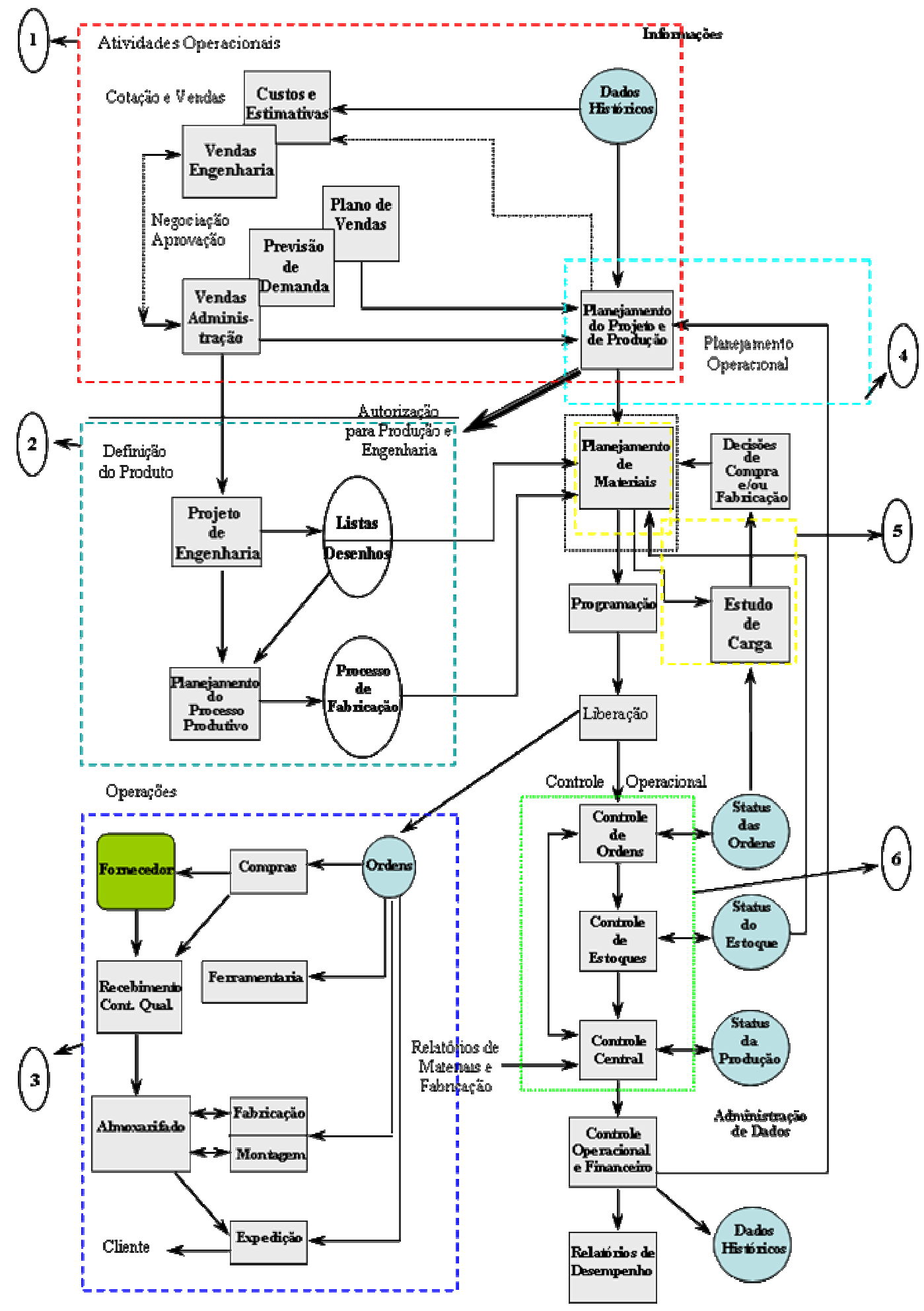

Figura 4: Esboço das atividades e inter-relações do PCP Fonte: RESENDE e SACOMANO (2000) 
Os recortes de 1 a 6 da figura correspondem aos subsistemas relacionados com o PCP e podem ser caracterizados como se segue (RESENDE E SACOMANO, 2000):

a) O recorte 1 refere-se à relação do PCP com o setor de vendas da empresa; é o subsistema para estabelecimento de preços, prazos e do plano de vendas e, por sua vez, resultará na previsão de demanda, informação essencial para o planejamento da produção;

b) Já o recorte 2 corresponde ao subsistema para definição do produto, o qual tem como saídas as listas de peças dos produtos (estruturas dos produtos), desenhos e processos de fabricação, informações de fundamental importância para o planejamento de materiais e para a programação das atividades nos centros produtivos e diz respeito ao interrelacionamento entre PCP e o departamento de Engenharia/Projeto;

c) $\mathrm{O}$ recorte 3 corresponde ao subsistema de fornecimento de materiais, armazenagem e expedição;

d) O recorte 4 está relacionado ao subsistema de definição da estratégia de produção, o qual, a partir de dados e informações derivados da estratégia da organização, desdobra-se no planejamento das atividades de produção;

e) O recorte 5 corresponde ao subsistema de definição de compras/fabricação, relacionado ao planejamento de materiais e à liberação das ordens de produção;

f) O recorte 6 esta relacionado ao subsistema de coordenação e controle das operações de fabricação, o qual avalia o status dos estoques, das ordens de produção e compra e do sistema como um todo, a fim de tomar medidas corretivas para a consecução dos planos de produção.

Este esboço, apresentado na figura 4, demonstra a necessidade de integração e a importância de um fluxo de informação eficiente do PCP com as demais áreas funcionais da organização, devido à sua complexidade e ao grande volume de informações envolvidas. 


\subsection{DIFICULDADES INERENTES ÀS ATIVIDADES DO PCP}

De acordo com Castro (2005), algumas dificuldades são inerentes ao planejamento e controle de produção, dentre elas:

a) Dificuldades de previsão de demanda - principalmente em sistemas que fabricam para estoque. Diz respeito à obtenção de melhores previsões de demanda de modo a refinar as decisões do quê, quanto e quando produzir ou comprar e de gerenciamento da capacidade de produção a fim de atender a demanda;

b) Dificuldades de gerenciar prazos e prioridades - em geral o prazo de entrega é imposto pelo cliente, havendo pouca possibilidade para o PCP avaliar a sua viabilidade. Em muitas ocasiões, o prazo de entrega baseia-se apenas no tempo de operação do item em questão; no entanto deveria ser considerado também o tempo de fila que o item aguarda para entrar nas máquinas ou centros de produção e que é muito difícil de prever, ainda mais quando o padrão de produção é variável, onde os tempos de set up são freqüentes e variáveis. Além do que, surgem ordens urgentes, as quais são encaixadas na programação da produção, dificultando o atendimento de prazos já acordados com o cliente;

c) Perda de eficiência devido a constantes mudanças na programação - quando a organização enfrenta um padrão de demanda variável, o dimensionamento de lotes para atendimento da carteira de pedidos e para a reposição de estoques de produto acabado é prejudicado, pois produtos diferentes do planejado devem ser fabricados gerando ineficiência e um custo de set up elevado, aumentando também o estoque de material em processo;

d) Dificuldades na gestão de recursos humanos - o aumento repentino de pedidos, ou seja, um padrão de demanda bastante variável obriga as pessoas responsáveis pelo PCP a administrar o contingente de mão-de-obra direta, estendendo turnos, contratando ou 
dispensando funcionários ou pagando horas extras, o que causa aumento nos custos de produção;

e) Dificuldades na gestão de estoques de matéria-prima - o PCP tem dificuldade em estabelecer datas e quantidades de compra de matérias-primas quando há baixa previsibilidade da demanda, convivendo com falta ou excesso de matéria-prima em estoque em função da variabilidade da demanda e do lead time de re-suprimento.

\subsection{CONSIDERAÇÕES SOBRE O CAPÍTULO}

A revisão bibliográfica realizada sobre o tema Planejamento e Controle de Produção apresentada neste capítulo possibilitou o reconhecimento da elevação da função produção a um papel estratégico para as organizações nas últimas décadas, e o papel da administração da produção como responsável por gerenciar e coordenar o sistema produtivo, destacando suas principais atividades.

Observou-se que a evolução tecnológica possibilitou a inserção de novas ferramentas na administração da produção, assim como as mudanças ocorridas nas demandas e exigências do mercado consumidor e competitivo impulsionaram seu desenvolvimento. Ainda, conforme mostrado pela evolução histórica abordada no capítulo, três momentos bem definidos na produção são caracterizados pela produção artesanal, pela produção em massa e pela produção enxuta.

Destacou-se a importância do acompanhamento do desempenho do sistema produtivo tendo como base seus objetivos de desempenho e suas medidas parciais.

A discussão sobre a estrutura e atividades do PCP permitiu um melhor entendimento dessa função no contexto organizacional, ressaltando-se a essência de suas atividades e a necessidade de integração às demais funções organizacionais, assim como algumas das possíveis dificuldades inerentes ao PCP. 


\section{ESPECIFICIDADES DA PEQUENA EMPRESA}

No período iniciado pelo capitalismo monopolista (1870) até o surgimento da terceira Revolução Industrial (1970), as empresas gigantescas dominaram o cenário empresarial com a quase exclusão das pequenas. Ao final do século $\mathrm{XX}$, com as novas tecnologias de informação e comunicação, com a reestruturação do papel do Estado e dos mercados e a conseqüente onda de ‘desverticalização’ das megaorganizações, ressurge a pequena empresa e sua importância para a sociedade. O momento atual é de atenção e crescente número de estudos dedicados à gestão e às características típicas das empresas não-gigantescas, ou genericamente denominadas pequenas empresas.

\subsection{PEQUENA EMPRESA}

As pequenas empresas são formas específicas de organização econômica, podendo ser industriais, comerciais, agropecuárias ou prestadoras de serviços, as quais combinam capital, trabalho, produção e comercialização para obter um bem ou serviço com a finalidade de satisfazer as necessidades de um determinado setor em um mercado consumidor. Estas empresas oferecem algumas contribuições, como, por exemplo, introduzem inovações, estimulam a competição e auxiliam as grandes ao prestar serviços complementares (CANDIDO, 2000; LONGENECKER, MOORE e PETTY, 1997).

Em conjunto com as microempresas, as pequenas possuem uma participação significativa na economia brasileira e de outros países, respondendo, no Brasil, por 99,2\% das 
empresas formais, por $57,2 \%$ dos empregos e por $26 \%$ da massa salarial (SEBRAE, 2005). Os dados da tabela 1 demonstram, de acordo com o porte, a contribuição das empresas no contexto brasileiro - destaque-se que estes dados referem-se apenas às empresas formais.

Tabela 1: Participação empresarial conforme o porte na economia brasileira

\begin{tabular}{r|r|r|r|r|r}
\hline \multicolumn{1}{c|}{ Porte } & \multicolumn{1}{c|}{$\begin{array}{c}\mathrm{N}^{\circ} \text { de } \\
\text { empresas }\end{array}$} & $\begin{array}{c}\text { Participação } \\
\%\end{array}$ & $\begin{array}{c}\text { Total de pessoas } \\
\text { ocupadas }\end{array}$ & $\begin{array}{c}\text { Participação } \\
\%\end{array}$ & $\begin{array}{c}\text { Participação } \\
\% \\
\text { (massa salarial) }\end{array}$ \\
\hline Pequena Empresa & 274.009 & $5,6 \%$ & 5.789 .875 & $21,0 \%$ & $15,7 \%$ \\
\hline Média Empresa & 23.652 & $0,5 \%$ & 2.700 .103 & $9,8 \%$ & $12,7 \%$ \\
\hline Grande Empresa & 15.102 & $0,3 \%$ & 9.104 .745 & $33,0 \%$ & $61,3 \%$ \\
\hline Microempresa & 4.605 .607 & $93,6 \%$ & 9.967 .201 & $36,2 \%$ & $10,3 \%$ \\
\hline Total & 4.918 .370 & $100,0 \%$ & 27.561 .152 & $100,0 \%$ & $100,0 \%$ \\
\hline
\end{tabular}

Fonte: SEBRAE (2005)

Classificar uma empresa como sendo de pequeno porte pode envolver diversos fatores, por exemplo, suas condições econômicas, produtivas ou setor de atuação entre outros. De forma geral, ao classificar o porte de uma empresa, podem ser utilizados critérios quantitativos (número de funcionários, faturamento etc), qualitativos (critérios específicos do setor de atuação, estrutura de gestão) ou, ainda, uma combinação de ambos de acordo com os fins do estudo e a realidade da empresa analisada.

Leone (1991) destaca que é possível compreender as empresas mediante o estudo do seu tamanho; dependendo do tamanho as empresas revelam comportamentos econômicos e sociais diferentes e, conseqüentemente, apresentam problemas diferentes, além de recursos distintos para solucioná-los. Almeida (1994) observa que cada empresa, em função de seu tamanho, tem características diferentes e esse, provavelmente, é o principal motivo de se estabelecer o porte como principal fator de classificação das empresas.

Dois critérios quantitativos são amplamente utilizados para a classificação do porte de empresas, sendo um deles o que leva em conta o número de funcionários e o setor de atuação 
da empresa, e outro o que leva em conta o seu faturamento bruto anual; ambos são apresentados nos quadros 3 e 4 , respectivamente.

\begin{tabular}{l|r|r}
\hline Setor & Comércio e Serviços & \multicolumn{1}{c}{ Indústria } \\
\hline Microempresa & até 09 & até 19 \\
\hline Empresa de Pequeno Porte & de 10 a 49 & de 20 a 99 \\
\hline Empresa de Médio Porte & de 50 a 99 & acima de 99 \\
\hline Empresa de Grande Porte & acima de 499 \\
\hline
\end{tabular}

Quadro 3: Classificação do porte das empresas segundo o número de funcionários Fonte: SEBRAE (2005)

\begin{tabular}{l|c|c}
\hline \multirow{2}{*}{ Porte } & \multicolumn{2}{c}{ Legislação Considerada } \\
\cline { 2 - 3 } & Estatuto da MPE & Simples Federal \\
\hline Microempresa & Até R\$ 244 mil & Até R\$ 240 mil \\
\hline \multirow{2}{*}{ Empresa de Pequeno Porte } & De R\$ 244 mil a & De R \$ 240 mil a \\
& $\mathrm{R} \$ 1,2$ milhão & $\mathrm{R} \$ 2,4$ milhões \\
\hline
\end{tabular}

Quadro 4: Classificação do porte das empresas segundo o faturamento bruto anual Fonte: SEBRAE (2006) e PORTAL TRIBUTÁRIO (2006)

Leone (1991) observa que os critérios quantitativos são econômicos e ajudam a explicar o comportamento social da pequena empresa e, por isso, são eles que determinam o porte das empresas. A autora destaca ainda o fato de tais critérios facilitarem a obtenção de dados, possibilitarem análises estatísticas e análises comparativas entre as empresas, além de serem de uso corrente.

Porém, a fim de compreender a pequena empresa e as características que as distinguem das de maior porte, os critérios qualitativos são mais adequados. Segundo Leone (1991, p.57), os critérios qualitativos "apresentam uma imagem mais fiel das empresas, uma vez que tocam, essencialmente, na sua estrutura interna, na sua organização e nos estilos de gestão”, passando mais uma visão de movimento da empresa, de ação gerencial, permitindo uma visualização da dinâmica da organização no seu dia-a-dia, ao invés da visão estática transmitida pelos critérios quantitativos. 
Silva (2004), ao realizar um levantamento em diversos autores sobre as características das empresas de pequeno porte, encontrou dentre as mais citadas a flexibilidade, a estrutura simples e a inovação como suas características marcantes.

Porém, algo que se destaca e merece bastante atenção no estudo das pequenas e microempresas é o alto índice de mortalidade registrado nelas. A pesquisa do Sebrae (2005) aponta que cerca de $60 \%$ das empresas encerram suas atividades após os cinco primeiros anos de funcionamento e como principais causas predominam as seguintes razões: falta de capital de giro $(24,1 \%)$, altos impostos e tributos $(16 \%)$, falta de clientes $(8 \%)$ e concorrência $(7,1 \%)$. De modo sintetizado, pode-se dizer que a alta taxa de mortalidade é decorrente de aspectos relacionados à gestão do empreendimento e de ordem econômica (SEBRAE, 2003).

Desta forma, em função da expressiva contribuição dessas empresas, tanto em termos econômicos quanto sociais, faz-se necessário um entendimento mais aprofundado de suas características de modo a dotá-las de ferramentas gerenciais mais adequadas à sua gestão, permitindo, também, um melhor alinhamento entre as ações de órgãos governamentais e de fomento no sentido de contribuir com a permanência delas na economia.

Alinhado a essa necessidade, serão apresentados na seção 4.2 e suas subseções as especificidades da pequena empresa. Tais especificidades são fruto da sistematização de diversos estudos contemplando o objeto de estudo pequena empresa e representam uma forma qualitativa de analisar seu porte.

\subsection{ESPECIFICIDADES DA PEQUENA EMPRESA}

Carvalho (2004, p.53) destaca que, considerando a "necessidade de uma abordagem diferenciada, adequada e realmente útil, é necessário compreender a gestão das pequenas empresas a partir de suas especificidades", tais como a escassez de recursos humanos, financeiros e materiais, a não-utilização de instrumentos administrativos formais por parte dos 
dirigentes, estrutura organizacional simples e reduzida entre outras. Necessitando, portanto, de um entendimento mais profundo dessas especificidades para um adequado diagnóstico e busca de possíveis soluções.

Albuquerque (2004, p.43) destaca que o entendimento das especificidades da pequena empresa é pré-requisito para que se possa contribuir com a sobrevivência e o sucesso dessa categoria de empresas, observando que "esse entendimento possibilitará a compreensão de como o comportamento do empreendedor, a estrutura, a tecnologia, a estratégia e os fatores externos à organização interagem, moldando as ações da pequena empresa”.

As teorias administrativas foram desenvolvidas em grandes empresas, sendo suas características organizacionais, problemas gerenciais e soluções empresariais muito diferentes daquelas da pequena empresa. Assim, diversos trabalhos (ALBUQUERQUE, 2004; CARVALHO, 2004; LEONE, 1999; LONGENECKER, MOORE e PETTY, 1997; MIGLIATO, 2004; NAKAMURA, 2000; SANCHES, 2005; SOUZA, 1995; TERENCE, 2002) buscaram destacar as características específicas das pequenas empresas, as quais encontram-se sistematizadas neste trabalho em sintonia com a proposta desenvolvida pelo Grupo de Estudos Organizacionais da Pequena Empresa (GEOPE), segundo a qual as especificidades estão classificadas em Ambientais, Estruturais, Estratégicas, Tecnológicas, Decisionais e Comportamentais, conforme apresentado no trabalho de Migliato e Escrivão Filho (2004).

Destaca-se que essa classificação das especificidades da pequena empresa é fundamentada em um modelo de concepção organizacional, evidenciando os diversos aspectos que compõem e envolvem uma organização, considerando ainda a inter-relação da empresa com o ambiente e o inter-relacionamento dos elementos organizacionais (MIGLIATO e ESCRIVÃO FILHO, 2004). 


\subsubsection{ESPECIFICIDADES AMBIENTAIS}

Pereira (1999) destaca que uma empresa é um sistema aberto e dinâmico, isto é, um conjunto de elementos interdependentes que interagem entre si para a consecução de um fim comum, em constante inter-relação com seu ambiente.

Desta forma, as especificidades ambientais da pequena empresa dizem respeito às forças provenientes do ambiente empresarial, as quais influenciam a sua gestão. O ambiente empresarial pode ser segmentado em dois componentes, sendo eles o macroambiente e o ambiente setorial; no macroambiente encontram-se as forças políticas, econômicas, sociais, legais e tecnológicas. Já o ambiente setorial é composto da estrutura de mercado na qual a empresa e seus concorrentes estão inseridos e as estruturas nas quais atuam seus fornecedores e compradores (MIGLIATO, 2004).

Carvalho (2004) destaca que não é possível estudar a gestão das pequenas empresas sem considerar o ambiente em que elas se inserem, pois elas não têm poder de influência perante grande parte das imposições de caráter legal, econômico, político, concorrencial entre outras provenientes do ambiente no qual estão inseridas. Essas imposições podem influenciar o desempenho da pequena empresa, exigindo, também, mudanças em sua gestão.

Para Souza (1995), as pequenas empresas como integrantes da estrutura produtiva podem ser dependentes ou independentes. Quando atuam de modo dependente, exercem uma função complementar direta ou indireta em relação às grandes empresas, sendo fornecedoras ou distribuidoras das grandes; nesta situação tem-se o modelo de coordenação, e a pequena empresa é subordinada às decisões da grande empresa. Já as que atuam de modo independente são as pequenas empresas que não mantêm relação direta com grandes, e, por sua vez, podem atuar em mercados competitivos tradicionais ou em estruturas industriais dinâmicas ou, ainda, estarem organizadas de maneira coletiva ou cooperativa, sendo este último caso denominado modelo comunitário. 
Porter (1986), ao propor uma metodologia para a análise de uma indústria, apresenta o que ele denominou de as cinco forças competitivas: ameaça de novos entrantes, ameaça de produtos ou serviços substitutos, poder de negociação dos compradores, poder de negociação dos fornecedores e o grau de rivalidade entre os concorrentes existentes. Neste ponto, Carvalho (2004) destaca que geralmente nos setores em que atua grande parte das pequenas empresas as barreiras de entrada tendem a ser baixas, aumentando a possibilidade de entrada de novas empresas e, conseqüentemente, a competição acirrada entre elas.

Destaca-se, ainda, que em virtude de seu volume reduzido tanto de venda quanto de compra, a pequena empresa possui baixo poder de negociação perante clientes e fornecedores, o que impacta em sua lucratividade. No extremo dessa situação, pode-se dizer que a pequena empresa sofre com o "efeito sanduíche", situação em que elas são compradoras de grandes fornecedores e fornecem para grandes clientes (MATTAR, 1988). Sanches (2005) destaca que nesta situação a pequena empresa apresenta grandes dificuldades para sobreviver, pois os preços de compra são impostos pelos fornecedores e os de venda pelos clientes, e no meio deste 'sanduíche' podem ser 'devoradas'.

Como outras especificidades ambientais da pequena empresa, Albuquerque (2004) cita: atuam nos limites do mercado, fornecendo produtos populares de baixo preço (baixa rentabilidade) ou produtos dirigidos a uma pequena parcela da população que não possui economias de escala; florescem em mercados restritos ou específicos que não apresentam atratividade econômica para as grandes empresas; são incapazes de exercer controle sobre os acontecimentos futuros do setor de atuação. 


\subsubsection{ESPECIFICIDADES ESTRUTURAIS}

Segundo Mintzberg (1995, p10), de maneira simples a estrutura de uma organização pode ser definida "como a soma total das maneiras pelas quais o trabalho é dividido em tarefas distintas e como é feita a coordenação entre essas tarefas".

Conforme Hall (2004), a estrutura organizacional deve atender a três funções básicas:

a) Possibilitar a realização de produtos organizacionais e a consecução de metas organizacionais;

b) Minimizar ou pelo menos regulamentar a influência das variações individuais sobre a organização, salientando-se que estruturas são impostas para assegurar que os indivíduos se conformem às exigências das organizações e não o inverso;

c) Ser o contexto onde o poder é exercido (as estruturas também estabelecem ou determinam quais posições têm poder sobre quais outras), onde as decisões são tomadas (determinando o fluxo de informação) e onde são executadas as atividades das organizações.

Hall (2004) destaca, ainda, três características fundamentais da estrutura organizacional:

a) A complexidade da estrutura organizacional esta relacionada ao grau de subdivisão das tarefas realizadas pelas pessoas na organização e ao número de níveis hierárquicos da estrutura organizacional;

b) A formalização da estrutura está relacionada ao processo pelo qual as organizações estabelecem normas e procedimentos e aos meios para assegurar que estes serão seguidos;

c) A centralização refere-se ao modo pelo qual o poder e a autonomia para tomada de decisão estão distribuídos pela organização, salientando-se que, quando a tomada de decisão é reservada apenas ao nível mais alto, a organização é centralizada.

De acordo com Albuquerque (2004), como especificidades estruturais da pequena empresa destacam-se: o fato de nestas empresas existirem poucas unidades de trabalho 
(cargos, seções entre outros) - formando uma estrutura simples; a predominância de um maior escopo de cargo para a função de direção; significativa despreocupação com os requisitos de um cargo; autoridade centralizada; e contato direto e informal entre dirigentes e funcionários.

Migliato (2004) salienta que a pequena empresa geralmente apresenta estrutura simples em conseqüência da necessidade de ter poucas unidades administrativas (restrição de recursos), a direção e os funcionários tendem a ser pouco especializados e o fluxo de informação é facilitado devido ao contato direto entre direção e funcionários.

\subsubsection{ESPECIFICIDADES ESTRATÉGICAS}

Albuquerque (2004) e Migliato (2004) realizaram um levantamento na literatura sobre as características da estratégia como componente do modelo de concepção organizacional e do processo para sua elaboração, a fim de relacioná-los à forma pela qual ambos ocorrem na pequena empresa. No que tange à utilização de técnicas de planejamento, os autores destacam um desconhecimento ou conhecimento parcial das técnicas por parte dos dirigentes, além de uma predominante falta de consciência a respeito da importância do planejamento estratégico e da falta de tempo para se dedicar a esta atividade. Destaca-se um alto grau de informalidade no processo de planejamento, ressaltando-se que a maior parte das atividades realizadas permanece na mente do dirigente. Além disso, o gerenciamento da informação é casual e não sistemático, o horizonte de planejamento concentra-se no curto prazo e a alocação de recursos é ineficaz, seja por sua falta ou má distribuição.

Nakamura (2000) aponta para a colocação de Michael Porter, segundo a qual quanto menor a empresa mais importante é a estratégia, isto porque as empresas menores, ao contrário das gigantes, são mais sensíveis às variações do mercado e, por isso, precisam perceber o ambiente competitivo com maior clareza e rapidez para garantir a sobrevivência nos negócios. Observa, ainda, que a pequena empresa, devido às suas características 
peculiares relacionadas ao seu tamanho, estrutura, cultura e limitações de recursos, apresenta obstáculos ao processo de formulação e estabelecimento de estratégias.

Golde (1986, p.11) destaca que "para a pequena empresa, planificar significa manipular enormes incertezas sobre as quais ela parece ter pouco controle"; desta forma, o planejamento é sempre deixado em segundo plano, resultando em uma série interminável de crises imediatas na luta pela sobrevivência cotidiana, as quais poderiam ser evitadas.

\subsubsection{ESPECIFICIDADES TECNOLÓGICAS}

Todas as organizações utilizam-se de algum tipo de tecnologia para realizar suas atividades; desde um simples editor de texto até a mais complexa e sofisticada tecnologia empregada em avançados processos de fabricação são fruto da aplicação da tecnologia nas organizações (SLACK et al., 1999).

Conforme Migliato (2004), as empresas são sistemas que adquirem, produzem e utilizam tecnologia para transformá-la em produtos e serviços e, dessa forma, a tecnologia pode ser definida como o conjunto de conhecimentos, ferramentas e ações necessárias para criar, produzir e distribuir bens e serviços de forma competitiva.

Albuquerque (2004) ressalta que a tecnologia é um componente organizacional e apresenta características típicas na pequena empresa. E como especificidades tecnológicas das empresas de pequeno porte o autor destaca: predominância do uso de tecnologias simples; equipamentos, técnicas e processos de produção, em sua maioria, obsoletos; insuficiência de recursos tecnológicos; menor probabilidade de produzir inovações radicais e maior possibilidade de produzir inovações incrementais. Por fim, o autor destaca que a diferença tecnológica que distancia a pequena da grande empresa é um grande desafio.

De outro modo, Migliato (2004) coloca como especificidade tecnológica da pequena empresa a carência de sistemas de máquinas e equipamentos, fazendo que essas empresas 
corram o risco de tornarem-se retrógradas, tecnológica e economicamente, em seus conhecimentos e competências.

\subsubsection{ESPECIFICIDADES DECISIONAIS}

Conforme Daft (2005), a tomada de decisões constitui-se da atividade de identificar problemas e oportunidades e então resolvê-los. Migliato (2004) destaca o fato das decisões poderem ser estratégicas, administrativas ou operacionais, individuais ou coletivas, racionais ou intuitivas; nas pequenas empresas, as decisões geralmente são de âmbito operacional e tomadas dentro e uma visão de curto prazo, pois o tempo e a habilidade do dirigente são precários, não possibilitando a ele tomar atitudes mais analíticas e estratégicas.

Além disso, destaca-se o fato de que, em geral, os dirigentes desse porte de empresa recusam-se a delegar o poder de decisão, figurando como os únicos decisores, salientando-se, ainda, que o processo de tomada de decisão é empreendido sem qualquer tipo de formalização, fundamentado na experiência, no julgamento ou na intuição do proprietáriodirigente (MIGLIATO, 2004).

Isso revela o estilo de liderança do dirigente da pequena empresa, o qual oscila entre autocrático e paternalista. Seu lado autocrático revela-se na centralização da tomada de decisão, observado nas empresas onde apenas ao 'patrão' cabem a decisões, restando aos empregados a mera execução adequada de suas tarefas. Já o lado paternalista revela-se pela interação do dirigente em assuntos pessoais e familiares dos empregados. Desta forma, cria-se um relacionamento entre patrão e empregado sem formalidade, e muitas vezes, o dirigente da pequena empresa passa por cima dos subordinados diretos, quebrando a linha hierárquica de autoridade (ESCRIVÃO FILHO, 1995). 


\subsubsection{ESPECIFICIDADES COMPORTAMENTAIS}

As especificidades comportamentais da pequena empresa estão relacionadas às características do comportamento dos seus dirigentes, os quais refletem seus valores, atitudes, desejos, motivações, competências, experiências, estilo de gestão entre outros, nas ações e decisões tomadas na gestão do empreendimento (ALBUQUERQUE, 2004).

Filion (1999), ao estudar os sistemas gerenciais de uma amostra de empresas em diversos países, destaca algumas diferenças entre os dirigentes com perfil empreendedor ou perfil de operadores de pequenos negócios.

Empreendedores são aqueles dirigentes que lideram empresas em rápido crescimento e que introduziram inovações significativas no negócio que atuam; o processo de gerenciamento deste tipo de dirigente é fortemente influenciado por sua capacidade de construir uma visão de futuro sobre e para o negócio, definindo meios e providenciando recursos para alcançá-la, assim como projetando uma estrutura organizacional capaz de suportar e manter o bom funcionamento do negócio.

Já os operadores de pequenos negócios são aqueles que lideram empresas que não apresentam crescimento rápido e não introduziram inovações significativas no mercado. Esse tipo de dirigente constrói um processo gerencial fortemente fundamentado em suas habilidades pessoais, vocação e experiência adquirida, resultando em empresas que não sobrevivem à ausência do líder por mais de alguns dias ou, no máximo, semanas.

Teixeira (1979) realizou algumas análises a fim de caracterizar o dirigente da pequena empresa. $\mathrm{O}$ autor comenta que o trabalho desses dirigentes é mais fragmentado, eles lidam com um elevado número de crises e imprevistos, passam mais tempo que os demais dirigentes com os subordinados dos subordinados, realizam um maior número e uma maior variedade de atividades e não controlam o emprego do tempo na sua rotina de trabalho. 
Por fim, destaca-se que o perfil do dirigente da pequena empresa, o qual irá resultar nas especificidades comportamentais verificadas nela, tem origens nas suas características pessoais, tais como: sua capacidade intelectual, seu nível de instrução, suas experiências e conhecimentos adquiridos entre outras (FILION, 1999).

\subsection{PLANEJAMENTO NA PEQUENA EMPRESA}

Considerando-se os dois tipos de planejamento, o estratégico e o operacional, e para o caso do operacional restringindo-se o foco de análise ao PCP, o que se observa na pequena empresa é que em ambos os casos são realizadas algumas atividades pertinentes a cada um dos tipos de planejamento, porém tais atividades ocorrem de modo não-sistemático e informal (HILL, 1987; ANDRADE, CARVALHO e ESCRIVÃO FILHO, 2004; ROBBINS e COULTER, 1998).

Como já destacado, a aplicação direta da literatura tradicional, desenvolvida com base nas organizações de grande porte, na pequena empresa é inapropriada por conta das características específicas destas empresas. Alinhados a essa perspectiva, diversos trabalhos foram realizados no âmbito do planejamento estratégico a fim de construir uma teoria que leve em conta as características da pequena empresa no processo de planejamento estratégico, tendo como objetivo tornar tal ferramenta administrativa de uso corrente nessas empresas.

Destacam-se os trabalhos de Fischmann e Almeida (1991) e de Almeida (2001), nos quais os autores apresentam um texto prático com o intuito de auxiliar potenciais usuários do planejamento estratégico, especialmente os dirigentes de pequenos empreendimentos. Esses potenciais usuários deixam de utilizá-lo por imaginar tratar-se de algo muito sofisticado, que requeira equipes onerosas ou experientes especialistas.

Outros trabalhos que também levam em conta esta preocupação: Golde (1986) destaca a necessidade de examinar as características básicas da empresa, analisar a forma pela qual 
tais características inibem o processo de planejamento, estudar alguns métodos de eliminar ou pelo menos reduzir os obstáculos ao planejamento; Terence (2002) propõe um roteiro prático para o processo de elaboração do planejamento; Migliato (2004) apresenta características do planejamento estratégico situacional e suas possibilidades de aplicação na metodologia de planejamento estratégico empresarial na pequena empresa.

Todos esses trabalhos e outros mais, que podem ser encontrados na literatura, abordando o problema na perspectiva das empresas de pequeno porte, procuram demonstrar a situação na qual se encontram as empresas deste porte em relação ao planejamento estratégico.

Já para o caso do PCP e, conseqüentemente, da Administração da Produção, poucos são os trabalhos que levam em conta e fazem uma análise mais qualitativa das características da pequena empresa no estudo desta forma de planejamento operacional. Um trabalho que considera as características específicas das empresas de pequeno porte é o de Hill (1987), no qual são destacadas algumas características particulares inerentes à administração da produção nessas empresas. Segundo o autor, predomina nelas um estilo mais intuitivo do que analítico, mais oportunista do que estratégico e isso, em muitos casos, representa para elas uma real força, porém pode representar uma potencial fraqueza na medida em que as crenças pessoais que norteiam a ação do dirigente da pequena empresa não são suficientes para o sucesso a longo prazo.

Desta forma, destaca-se a necessidade da realização de estudos mais aprofundados sobre o PCP na pequena empresa, pois, como apontado por Slack et al. (1999, p.229), "qualquer operação produtiva requer planos e controle, mesmo que a formalidade e os detalhes dos planos e do controle possam variar". Resende e Sacomano (2000) corroboram a idéia da necessidade de alinhar o PCP às características da empresa ao afirmarem que a dimensão da empresa e do departamento de PCP influi fundamentalmente na procura da 
melhor maneira para programar e liberar a produção, assim como os procedimentos para cada fábrica devem ser talhados conforme as suas necessidades.

Berman Gordon e Sussman (1997), ao realizarem um estudo buscando determinar os beneficios derivados da sofisticação do planejamento para empresas de pequeno porte, destacam como resultados do estudo uma correlação positiva entre técnicas sofisticadas de planejamento e desempenho; no entanto, os autores ressaltam que o maior problema em estudos sobre o processo de planejamento nessas empresas é o fato de que, tipicamente, uma minoria delas está engajada em atividades de planejamento. Lyles et al. (1993) também destacam como resultado de seu estudo uma significativa diferença de desempenho entre empresas que utilizam planejamento formal ou sofisticado em relação àquelas que não o fazem.

\subsection{CONSIDERAÇÕES SOBRE O CAPÍTULO}

A revisão bibliográfica desenvolvida neste capítulo demonstrou o papel significativo das pequenas empresas no contexto socioeconômico brasileiro, as quais, em conjunto com as microempresas, geram uma parcela expressiva do emprego e renda, além de outras contribuições no ambiente de negócios.

As pequenas empresas possuem características específicas que as distinguem das de grande porte, e isso impossibilita a aplicação direta das teorias administrativas desenvolvidas com base nas características da grande empresa. Tais características específicas, sumarizadas como especificidades ambientais, estruturais, estratégicas, tecnológicas, decisionais e comportamentais, foram apresentadas no capítulo e servem como parâmetros qualitativos para se analisar a pequena empresa. 
Diversos indícios e colocações sobre o planejamento na pequena empresa foram encontrados na literatura, e a constatação principal que se obtém é o fato de que nelas há algum nível de planejamento, porém de forma não sistemática e informal. 


\section{TRABALHO DE CAMPO}

O propósito deste capítulo é apresentar a descrição do trabalho de campo, os métodos de pesquisa empregados para a obtenção e análise dos dados empíricos, uma caracterização do setor e da empresa objeto de estudo.

\subsection{MÉTODOS DE PESQUISA}

Segundo Demo (2001), o grande desafio da pesquisa científica é a integração entre teoria e prática, constituindo-se na forma de intervenção no objeto de estudo e na capacidade do pesquisador em reconhecer as relevâncias do cenário e tirar conclusões.

Nas seções seguintes, serão apresentadas: a caracterização da pesquisa, suas questões, suas variáveis, as técnicas de coleta e de análise de dados.

\subsubsection{CARACTERIZAÇÃO DA PESQUISA}

Visando atingir o objetivo proposto, foi realizada uma investigação junto a uma pequena empresa metalúrgica de São Carlos/SP, sendo o pesquisador um integrante do quadro de funcionários da empresa, na função de supervisor de PCP.

A escolha da empresa objeto de estudo do presente trabalho se deu em razão de uma atividade de estágio do curso de graduação em Engenharia de Produção realizada pelo pesquisador, com duração de um ano, no período de novembro de 2003 a outubro de 2004, junto ao departamento de Planejamento e Controle da Produção da empresa. Durante esse período, observou-se que os objetivos da produção, por vezes, são prejudicados devido a: 
excessiva centralização de poder, problemas de coordenação do trabalho e falta de planejamento sistemático das atividades operacionais.

Além disso, a empresa configurou-se como uma excelente oportunidade de pesquisa pelo fato de estar em fase de implantação de um sistema informatizado integrado para a gestão do negócio (nos moldes de um ERP), e em processo de certificação ISO 9001:2000, os quais exigiriam mudanças em sua gestão e, conseqüentemente, revelariam o comportamento da pequena empresa diante de tais mudanças de nível organizacional.

Devido a suas características, esta pesquisa pode ser classificada como (SILVA e MENEZES, 2000, p.20-21):

- Quanto a sua natureza: como aplicada, pois "objetiva gerar conhecimentos para aplicação prática, dirigidos à solução de problemas específicos”, e o pesquisador desempenhou concomitantemente o papel de supervisor de PCP na empresa estudada;

- Quanto à forma de abordagem do problema: como qualitativa, pelo fato de considerar “uma relação dinâmica entre o mundo real e o sujeito, ou seja, um vínculo indissociável entre o mundo objetivo e a subjetividade do sujeito que não pode ser traduzido em números";

- Em relação a seus fins: a pesquisa pode ser caracterizada como descritiva, pois "visa descrever as características de determinada população ou fenômeno ou o estabelecimento de relações entre variáveis";

- Quanto aos seus procedimentos técnicos: como estudo de caso, pois "envolve o estudo profundo e exaustivo de um ou poucos objetos de maneira que permita o seu amplo e detalhado conhecimento". Yin (2001, p.32) complementa afirmando que o método de estudos de caso "é uma investigação empírica que investiga um fenômeno contemporâneo dentro de um contexto da vida real, especialmente quando os limites entre o fenômeno e o 
contexto não estão claramente definidos", e no qual múltiplas fontes de evidência são usadas.

\subsubsection{QUESTÕES DA PESQUISA}

A revisão bibliográfica desenvolvida demonstra que a pequena empresa possui características específicas que a distingue das de maior porte e por isso demanda um processo de gestão diferenciado. Por outro lado, alguns trabalhos apresentam os possíveis ganhos gerados pelo aperfeiçoamento das atividades de planejamento nestas empresas como forma de prepará-las para enfrentar e responder às demandas do negócio.

Dessa forma, as questões da pesquisa são as seguintes:

- Quais mudanças organizacionais ocorreram a partir de 2004 com a estruturação do planejamento e controle da produção?

- A maior sofisticação do planejamento operacional - com a sistematização das atividades do PCP - representou melhor desempenho da empresa?

- De que forma as especificidades organizacionais da pequena empresa influenciaram favorável, ou desfavoravelmente, na sistematização do planejamento e controle da produção?

\subsubsection{VARIÁVEIS DA PESQUISA}

Segundo Triviños (1987, p.107), as variáveis de pesquisa "são características observáveis de algo que podem apresentar diferentes valores”, devendo a variável, na pesquisa quantitativa, ser medida e, na pesquisa qualitativa, ser descrita. Para Collis e Hussey (2005), uma variável é um atributo da entidade escolhida como unidade de análise e pode assumir valores diferentes ao longo do tempo e entre entidades diferentes.

De acordo com o objetivo proposto, são variáveis da pesquisa:

- Especificidades organizacionais da pequena empresa: caracteriza-se pelo comportamento diferenciado da pequena empresa em relação aos elementos 
organizacionais, e suas inter-relações. As especificidades são compostas pelos seguintes elementos: ambientais, estruturais, estratégicos, tecnológicos, decisionais e comportamentais;

- Sistematização do planejamento e controle da produção (PCP): caracteriza-se pela sistematização do conjunto de atividades que determinam um plano operacional para a produção e que fazem a interligação da produção com os demais setores administrativos da empresa, a fim de responder à demanda por produtos e serviços. O conjunto de atividades do PCP é composto pelas seguintes atividades principais: previsão de vendas e gestão da carteira de pedidos, planejamento agregado de produção, planejamento mestre de produção, planejamento das necessidades de materiais, controle de estoques, programação da produção, planejamento e controle da capacidade e controle de produção;

- Desempenho da empresa: refere-se ao resultado obtido pela empresa em determinado período, medido aqui neste estudo por meio do volume de vendas anual.

\subsubsection{TÉCNICAS DE COLETA E ANÁLISE DE DADOS}

Conforme Silva e Menezes (2000), a definição do instrumento de coleta e da forma de análise dos dados depende dos objetivos almejados com a pesquisa e do universo a ser investigado.

O processo de coleta de dados desta pesquisa foi realizado por meio de observações propiciadas pela atuação na empresa estudada (observação participante/observação livre), pela análise de documentos existentes na empresa (exame documental) e entrevistas realizadas com roteiros semi-estruturados. Os dados obtidos, assim como os fatos e acontecimentos relevantes observados no decorrer da atuação profissional junto à empresa, foram apontados em diário de campo e compõem as análises deste trabalho. Os roteiros de entrevista 
encontram-se disponíveis nos apêndices A e B. O diário encontra-se disponível no apêndice C.

No processo de análise dos dados obtidos foram empregadas técnicas qualitativas e quantitativas. A análise qualitativa dos dados foi empregada no momento em que as observações apontadas, tanto nas observações livres quanto nas entrevistas, foram agrupadas em categorias e confrontadas com a teoria a fim de se obter conclusões. A análise quantitativa foi empregada principalmente como forma de medir o desempenho da empresa, levando-se em conta o seu volume de vendas anual.

\subsection{CARACTERIZAÇÃO DO SETOR METAL-MECÂNICO}

Segundo o Dieese (1998), o setor metal-mecânico brasileiro é composto por diversos segmentos empresariais, entre eles o das empresas eletroeletrônicas, de bens de capital, automotivas, siderúrgicas, produtoras de alumínio e fundições.

No site do Ministério do Trabalho e Emprego (MTE), encontra-se disponível a Classificação Nacional das Atividades Econômicas (CNAE). Nesta classificação são apresentadas uma série de atividades e subatividades, permitindo um enquadramento das empresas. O que se observa nesta classificação é que elas não são agrupadas como pertencentes ao setor metal-mecânico, mas apenas em função de sua atividade principal.

Outra forma de classificação das empresas em função do setor de atuação é encontrada no site de investimentos do governo do estado de São Paulo. Neste site um conjunto de setores é apresentado e aqueles que estão relacionados ao setor metal-mecânico são três: Máquinas e Equipamentos, Metalurgia Básica e Automotivo. No grupo de empresas produtoras de máquinas e equipamentos estão incluídas as empresas fabricantes de motores, bombas, compressores, equipamentos de transmissão, máquinas e equipamentos de uso geral, fabricação de eletrodomésticos entre outros. Já o grupo de empresas pertencentes à metalurgia 
básica é composto por empresas produtoras de ferro-gusa e ferro-liga, siderurgia, fabricação de tubos, metalurgia de metais não-ferrosos e fundição. No grupo de empresas automotivas estão aquelas que são pertencentes à cadeia produtiva de veículos automotores.

Motta (2000) destaca ser difícil classificar as empresas como sendo do setor metalmecânico ou não. Segundo a autora, com o avanço tecnológico e a integração da mecânica, eletrônica, mecatrônica e outras áreas do conhecimento para a produção de máquinas e demais produtos, torna-se difícil a separação dos setores, pois tudo está muito integrado. A fim de classificar as empresas como pertencentes ao setor metal-mecânico, essa autora utilizou em seu trabalho a classificação fiscal das empresas quanto ao ramo de atividade.

Neste trabalho, a fim de classificar a empresa estudada como pertence ao setor metalmecânico, foi utilizada a classificação proposta pelo Dieese, pelo fato de se tratar de uma proposta mais abrangente que contempla as demais classificações encontradas. Os segmentos empresariais que compõem essa classificação são (DIEESE, 1998):

a) Eletroeletrônicas - empresas de telecomunicações, fabricantes de bens eletrônicos de consumo (imagem, som, linha branca e portáteis), empresas de informática e de automação industrial;

b) Bens de capital - empresas fabricantes de máquinas e equipamentos utilizados na produção de outros bens;

c) Automotivas - empresas montadoras de automóveis e fabricantes de autopeças;

d) Siderurgia - indústrias produtoras de aço, produtoras de laminados de aço, semi-acabados e tubos de aço;

e) Alumínio - empresas produtoras de alumínio primário, usinas secundárias e indústrias transformadoras, produtoras de laminados e chapas, fundidos e forjados;

f) Fundição - empresas fornecedoras de produtos semi-acabados para outros setores industriais da economia, caracterizadas pelo processo industrial composto pela fusão de 
ferro, aço ou outros materiais não ferrosos, seguida pelo lançamento deste material em moldes.

As empresas do setor metal-mecânico contribuem significativamente para a economia brasileira. Dados do IBGE (2006) apontam que as empresas deste setor estão entre aquelas de maior impacto nos índices de crescimento da indústria, destacando-se as empresas fabricantes de máquinas e equipamentos com $20,6 \%$ de crescimento, veículos automotores com $12,9 \%$ e metalurgia básica com 7,6\%.

O estado de São Paulo representa a maior força do setor metal-mecânico do país. Conforme pesquisa feita pelo IBGE (2006), a indústria paulista empregou aproximadamente $21 \%$ da população ativa e gerou $44 \%$ do PIB do estado.

Segundo o SEADE (2004), esse setor é tradicionalmente reconhecido como estratégico para o desenvolvimento, em função de seu desempenho no processo de acumulação de capital, na geração e difusão do progresso técnico. Destaca-se, ainda, que ele apresenta maior concentração na região metropolitana de São Paulo, seguida pelas regiões de Campinas, Sorocaba, Araraquara e São Carlos.

\subsection{HISTÓRICO E DESCRIÇÃO DA EMPRESA}

O objetivo desta seção é apresentar o histórico da empresa desde sua fundação e uma descrição dos seus departamentos.

\subsubsection{HISTÓRICO DA EMPRESA}

Fundada em outubro de 1996, a empresa objeto de estudo ${ }^{1}$ é uma metalúrgica de pequeno porte que conta com uma equipe 51 funcionários em maio de 2007, distribuídos nas

\footnotetext{
${ }^{1}$ A fim de manter o sigilo em relação ao nome da empresa e evitar sua exposição desnecessária, seu nome será suprimido do texto e ela será referenciada como "empresa", "empresa objeto de estudo" ou "empresa estudada".
} 
áreas de vendas, financeiro, suprimentos, engenharia/projeto, $\mathrm{PCP}$, controle de qualidade, recursos humanos e produção.

A empresa está instalada na cidade de São Carlos-SP e é especializada no projeto, fabricação e comercialização de produtos e acessórios utilizados no controle e otimização de linhas de distribuição de fluidos industriais (gases e líquidos), utilizados nas mais diversas aplicações empresariais (indústrias têxteis, alimentícias, de transformação, químicas, petroquímicas entre outras), podendo ser caracterizada como uma empresa produtora de bens de capital do setor metal-mecânico.

A empresa nasceu da identificação de uma oportunidade de mercado por seu proprietário-dirigente, que aproveitou suas experiências adquiridas em uma multinacional atuante no mesmo setor de negócios e que hoje é sua principal concorrente no mercado.

Sua linha de produtos é bastante diversificada e sua produção pode ser caracterizada como um misto entre produção seriada intermitente e sob encomenda (caso de peças para aplicações específicas). Desde sua fundação, a empresa conquistou diversos clientes não só na esfera nacional como internacional, sendo EUA, Portugal, Espanha, Bolívia, Uruguai, Paraguai e Chile exemplos de países em que possui clientes assíduos.

Sua carteira de clientes é composta predominantemente por revendas e empresas de manutenção, os quais representam cerca de $90 \%$ do volume de vendas. Os clientes possuem como fatores decisivos para compra o prazo de entrega e o preço do produto, buscando desta forma minimizar seus estoques e maximizar sua margem de lucro. Predominantemente, eles são de pequeno e médio porte e estão localizados principalmente nas capitais dos estados brasileiros ou próximo de pólos industriais.

Seus principais fornecedores são fundições, distribuidores de aços (barras e chapas), e distribuidores de componentes para fixação (parafusos, porcas e prisioneiros). No geral, são de médio porte e estão localizados nas proximidades de São Carlos e em São Paulo. 
Devido ao rápido crescimento do volume de vendas e à necessidade de melhorar a gestão operacional do negócio profissionalizando sua gestão, recorreu-se à contratação de um estagiário da área de engenharia de produção para dar suporte às atividades de PCP. Assim, teve início a atuação do pesquisador na empresa. Destaca-se que, após a conclusão do período de estágio, o pesquisador foi contratado na função de supervisor de PCP.

A empresa objeto de estudo possui um único proprietário e está em seu comando desde sua fundação. No início de suas atividades, ela contava com seis funcionários e sua linha de produtos era composta por apenas uma das dezenove famílias de produtos atuais. Seu volume de vendas nos dois primeiros anos de atividade girava em torno de 7 a $8 \%$ do realizado em 2006 e sua carteira de vendas era composta predominantemente por pedidos de um único cliente, uma empresa revendedora de grande porte.

A partir de meados de 2000, com o lançamento de um produto com alto teor tecnológico e início da sistematização da área de vendas com a contratação de um gerente experiente para o departamento, iniciou-se uma forte investida da empresa rumo a novos clientes. Concomitantemente, ocorreu a contínua diversificação da linha de produtos, abrindo então novas oportunidades de negócio.

Desde sua fundação, seu principal concorrente é uma multinacional com matriz sediada na Inglaterra e dezesseis filiais, sendo estas localizadas no Brasil, EUA, México, Argentina, Itália, Canadá, África do Sul, Austrália, China, Índia, Japão, Coréia, Espanha, Taiwan, França e Alemanha. Esta multinacional é o maior fabricante de equipamentos neste setor de negócios do mundo.

Quando a empresa objeto de estudo entrou em operação, a meta de seu dirigente era conquistar uma fatia de mercado que buscava uma melhor relação custo/benefício. Nesta ocasião, o marketing da empresa concentrava-se em disponibilizar para o mercado uma opção de escolha totalmente nacional, com custo inferior e qualidade similar. 
Com o passar dos anos e a contínua penetração da empresa e seus produtos no mercado, a marca da empresa se consolidou e, por este motivo nos anos de 2001, 2002 e 2003 foi registrada uma taxa média de crescimento de $63 \%$ ao ano. Nesse momento foi necessário estruturar a empresa para suportar o crescimento, e isso se deu através da contratação de funcionários qualificados para dividir com o dirigente as tarefas necessárias para a gestão do negócio. Desta forma, recorreu-se à contratação de responsáveis para o departamento financeiro, para o departamento de suprimentos, para o PCP e para a fábrica.

A busca por uma melhor estruturação do negócio se deu, principalmente, devido à necessidade de profissionalizar a gestão e sustentar o crescimento obtido até então. A partir de meados de 2003, uma nova empreitada rumo à profissionalização da gestão da empresa foi iniciada com a aquisição de um software integrado de gestão nos moldes de um ERP e com o início do processo de certificação ISO 9001:2000.

O software de gestão foi adquirido de uma consultoria de pequeno porte sediada também no interior de São Paulo, a qual o desenvolveu e já o havia implantado em outras duas empresas. A idéia principal com a implantação deste software foi criar uma base de informação (independente do conhecimento até então disponível apenas na cabeça das pessoas) e fornecer aos membros da empresa uma ferramenta de gestão que auxiliasse a condução de suas atividades, assim como mecanismos de controle mais apurados com a possibilidade de emissão de relatórios gerenciais.

Para o processo de certificação ISO 9001:2000, recorreu-se à contratação de um consultor externo para assessorar todo o processo na empresa. Neste caso, o atrativo residiu na possibilidade de acesso a novos mercados (clientes que exigem a certificação como fator qualificador para o fornecimento de materiais) e posteriormente na possibilidade de usá-la como mecanismo de gestão operacional, obrigando os responsáveis das áreas a seguir alguma 
sistemática em suas atividades operacionais com a sua avaliação por meio de indicadores de desempenho.

\subsubsection{DESCRIÇÃO DA ÁREA ADMINISTRATIVA}

A empresa encontra-se estruturada conforme o organograma apresentado na figura 5, porém muitos resquícios da fase anterior na qual o dirigente centralizava todas as questões administrativas do negócio são encontrados em sua gestão atual, por exemplo, a distribuição de ordens diretas e serviços para os subordinados sem passar pela linha hierárquica natural (gerentes e/ou supervisores das áreas).

A empresa encontra-se segmentada na forma de departamentos (vendas, financeiro, suprimentos, engenharia/projeto, PCP, controle de qualidade, recursos humanos, diretoria e fábrica). A área administrativa da empresa compreende a diretoria, os departamentos de vendas, financeiro, recursos humanos e suprimentos, destacados com fundo amarelo na figura 5. 


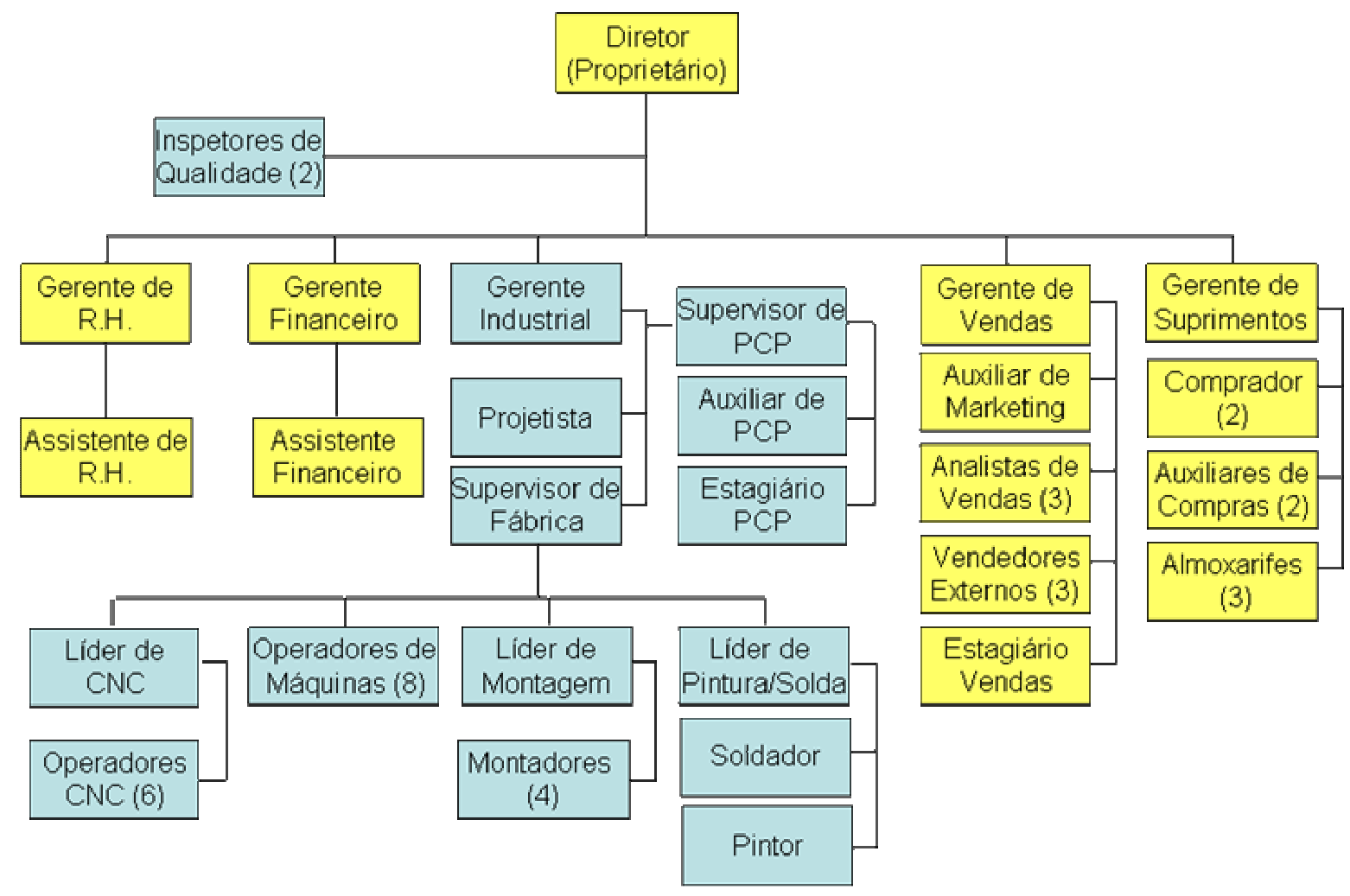

Figura 5: Organograma da empresa estudada

Fonte: Manual da qualidade da empresa

\section{a) Diretoria}

A diretoria da empresa é composta apenas por seu proprietário-dirigente, o qual realiza o acompanhamento global do negócio, gerando metas operacionais e cobrando sua consecução pelos responsáveis dos departamentos e áreas da empresa; mantém contatos com clientes-chave; desenvolve novos produtos a fim de gerar uma opção similar no mercado para produtos de concorrentes ou atender necessidades específicas de determinados clientes; e monitora o mercado de atuação da empresa identificando oportunidades e ameaças.

O dirigente possui nível superior em Física. Ele adquiriu conhecimentos em processos de fabricação no curso de Tecnólogo em Processos de Produção da FATEC e cursos técnicos no SENAI na sua juventude e possui vasta experiência no setor de atuação em virtude da atuação desde o chão-de-fábrica até os setores administrativos da multinacional que atualmente é sua principal concorrente. 
Além da experiência adquirida na empresa multinacional, o dirigente passou pela área de projetos de uma empresa de equipamentos de informática e foi proprietário de outros três empreendimentos antes do atual.

Seu perfil é bastante técnico e, a fim de suprir sua carência de conhecimentos administrativos, ele realizou recentemente um MBA na área de gestão de negócios e cursos relativos a rotinas administrativas (compras, negociação e financeiras). Ele adotou como estratégia a contratação de funcionários com conhecimentos específicos para liderarem os setores da empresa, dividindo, deste modo, as responsabilidades administrativas.

\section{b) Departamento de vendas}

O departamento de vendas tem como responsabilidades atrair novos clientes, reter os clientes já conquistados, monitorar as investidas da concorrência, manter atualizada a lista de preços dos produtos, identificar oportunidades para realizar promoções e as atividades de contato com o cliente (cotações de preços e prazos, esclarecimento de dúvidas e disponibilização de informações técnicas sobre o produto).

Este departamento conta atualmente (maio de 2007) com um gerente, um auxiliar de marketing, três analistas de vendas, três vendedores externos e um estagiário da área de engenharia mecânica.

O gerente de vendas tem o papel principal de conduzir o departamento rumo ao cumprimento de suas metas, realizar atendimentos técnicos (dimensionando e recomendando produtos de acordo com as necessidades e requisitos do cliente), assim como realizar visitas a clientes nacionais e internacionais, a fim de manter o contato com eles e gerar novas vendas.

O auxiliar de marketing cuida dos materiais de divulgação da empresa e seus produtos e, predominantemente, atua como analista de vendas tendo em vista o fato de que as atividades de marketing tomam apenas uma parcela de seu tempo. 
À função de analista de vendas estão atribuídas as atividades de realizar o atendimento de clientes via telefone, e-mail ou fax; montar propostas de vendas com base em consultas realizadas pelo cliente; realizar contatos com clientes buscando esclarecer dúvidas sobre pedidos e certificá-los sobre prazos de entrega tendo como base as informações obtidas junto ao PCP. Apenas um dos três analistas de vendas tem a função específica de atender os clientes de exportação, e, por sua vez, atua na empresa em tempo parcial e realiza todo o desembaraço da documentação junto a despachantes, transportadores especiais, confeccionando também os documentos pertinentes ao processo de exportação de cada país de destino. Outro analista de vendas soma a suas atividades a função de realizar a comunicação PCP-vendas-financeiro, realizando as atividades de emissão de notas fiscais e preparação da documentação para envio do produto (etiquetas para as embalagens, autorização de expedição e a própria nota fiscal).

Os vendedores externos utilizam seu tempo visitando clientes e permanecendo em revendas parceiras a fim de levantar informações sobre os produtos e seu funcionamento e identificar oportunidades para novos negócios. A eles são atribuídas regiões geográficas de atuação.

O estagiário está sendo treinado para reforçar a especificação técnica do produto junto aos clientes, compondo uma estrutura para o desenvolvimento de um setor de engenharia de aplicação dentro do departamento de vendas.

A fim de reforçar sua atuação junto ao mercado consumidor, a empresa tem como parceiros de negócio revendas autorizadas de seus produtos distribuídas pelo país e empresas especializadas em manutenções industriais nas linhas de distribuição de fluidos. A esses parceiros são concedidos descontos especiais na venda do produto e melhores prazos de pagamento. Tais parcerias são na verdade uma estratégia de vendas para contornar a limitada força de penetração no mercado da empresa, ocasionada por seu porte reduzido. 
A previsão de demanda é extremamente deficiente, ocasionada principalmente pela alta variação do volume de vendas para as famílias de produtos durante o ano. Outro aspecto que dificulta bastante a previsão de demanda é a grande variedade de produtos (por volta de 4000 configurações de produtos finais) e o fato de alguns deles serem peças críticas em processos industriais, havendo a necessidade de fabricar produtos pouco rotineiros com prazos curtos. Isso ocorre em razão de manutenções não-programadas e da intencionalidade dos clientes em não manter peças sobressalentes em seu estoque.

\section{c) Departamento financeiro}

Ao departamento financeiro são delegadas as responsabilidades orçamentárias (contas a pagar e receber), o acompanhamento do fluxo de caixa e a manutenção de contatos junto a instituições financeiras a fim de suprir as necessidades financeiras da empresa e encontrar as melhores alternativas de aplicação para os recursos disponíveis.

Até março de 2005 este departamento era composto por um gerente e uma assistente, porém desde então ele ficou sob a responsabilidade apenas da assistente e, por alguns períodos, houve a contratação de auxiliares para assessorar a assistente em suas atividades. Atualmente (maio de 2007), ele está composto apenas pela assistente, que divide com o dirigente as atividades anteriormente desenvolvidas pelo gerente financeiro. $\mathrm{O}$ departamento conta também com o auxílio de um consultor externo que a cada quinze dias comparece na empresa para assessorar a assistente do departamento, fazer recomendações de melhoria e realizar uma análise global da situação financeira do empreendimento.

Por três vezes, desde a permanência do pesquisador na empresa, foi cogitada a possibilidade de se aceitar a entrada de investidores externos a fim de se obter recursos financeiros para alavancar sua operação, inclusive em uma delas a empresa foi selecionada para participar de um congresso, promovido pelo Ministério da Ciência e Tecnologia em 
2005, para a exposição de empresas brasileiras com potencial para receber recursos de investidores estrangeiros. Porém essa intenção ainda não foi concretizada.

Fato já destacado na literatura para o caso de empreendimentos de pequeno porte e comum na empresa objeto de estudo é a escassez de recursos financeiros, que são obtidos, para a manutenção do fluxo de caixa, por meio do desconto antecipado de títulos referentes às vendas a prazo, junto aos bancos nos quais ela realiza movimentações financeiras.

Por fim, destaca-se que na empresa não há um planejamento financeiro detalhado e sistemático realizado antecipadamente, sendo as necessidades financeiras reais geradas com poucos dias de antecedência e ficando sob poder da assistente do departamento financeiro e do dirigente. Este último repassa metas para o departamento de vendas (necessidade de gerar mais negócios) e para o departamento de suprimentos (necessidade de conter gastos ou reprogramar pagamentos junto aos fornecedores).

\section{d) Departamento de recursos humanos}

O departamento de recursos humanos executa as atividades de contratação e seleção de pessoal, programação de treinamentos para funcionários, acompanhamento de cartão de ponto via sistema informatizado, gerenciamento das necessidades de higiene e segurança do trabalho (apontadas por uma consultoria terceirizada especializada, contratada a fim de manter a empresa em conformidade com as normas do ministério do trabalho), agendamento de consultas médicas para funcionários entre outras.

Este departamento conta com uma gerente e uma assistente. A gerente executa as atividades de resolver conflitos de maior relevância, cobrar os responsáveis dos demais departamentos sobre problemas com seus subordinados, solucionar questões legais trabalhistas, contratar serviços terceirizados e estruturar as atividades pertinentes ao RH. A assistente realiza as demais atividades operacionais do departamento: fechamento de folha de 
pagamento, agendamento de consultas, recrutamento de funcionários, manutenção de arquivos dos funcionários, entre outras.

Aspecto bastante valorizado na política de RH da empresa é a contratação de jovens recém-formados pelo SENAI da cidade, especificamente do curso de mecânico de usinagem. Isso é muito vantajoso para a empresa, pois possibilita a formação de mão-de-obra técnica capacitada para atuar na área produtiva a um custo mais baixo.

As principais dificuldades verificadas no departamento de RH estão relacionadas à alta rotatividade de funcionários, sendo apontados pelo pesquisador um número de quarenta e oito funcionários diferentes que passaram pela empresa desde novembro de 2003 e que já se encontram desligados dela; dificuldades relacionadas à disponibilização de benefícios aos funcionários (plano de saúde, cesta básica entre outros), devido ao seu reduzido número de funcionários e, conseqüentemente, pouca representatividade perante empresas de planos de saúde e assistência médica, inviabilizando tal benefício devido ao elevado custo tanto para a empresa quanto para os funcionários; outra dificuldade reside na impossibilidade de se manter na empresa funcionários qualificados, os quais são 'assediados' e contratados por outras empresas que lhes oferecem uma condição melhor (dezenove dos quarenta e oito casos de funcionários que passaram pela empresa).

\section{e) Departamento de suprimentos}

O departamento de suprimentos é responsável por efetuar as compras de materiais e para tanto, realiza cotações e negociações junto a fornecedores e o acompanhamento de prazos de entrega. Sua principal meta é buscar opções de fornecimento que tenham melhores prazos, custos mais baixos e um nível de qualidade adequado, priorizando também a manutenção de baixos volumes de estoque. O almoxarifado da empresa encontra-se hierarquicamente subordinado a este departamento, que é responsável pela organização física e pelo controle do estoque, sendo esta última atividade realizada em parceria com o PCP. 
Para realizar as atividades que são de sua atribuição, o departamento de suprimentos conta com uma equipe de oito funcionários: um gerente, dois compradores, dois auxiliares e três almoxarifes.

Ao gerente de suprimentos cabem as responsabilidades de fazer o acompanhamento dos processos de compra em andamento a fim de monitorar o cumprimento das metas (financeiras e relacionadas a prazo de entrega); realizar a aprovação das melhores condições de compra e posteriormente passá-las na forma de pedidos de compra para a aprovação da diretoria; realizar contatos com fornecedores a fim de negociar melhores prazos de entrega e melhores condições de pagamento.

Os compradores responsabilizam-se por desenvolver novos fornecedores; realizar cotações de preços a partir das necessidades de compras passadas pelo PCP na forma de 'solicitações de compra' e fazer follow-up ${ }^{2}$ de pedidos de compra junto aos fornecedores. Um dos compradores encarrega-se ainda de visitar fornecedores quando há a necessidade de cobrar a entrega de peças urgentes ou até mesmo buscá-las.

Os auxiliares de compras são responsáveis pela organização da documentação referente aos processos de compra já realizados e em andamento; pela comunicação com fornecedores no que diz respeito à transmissão de fax, desenhos contendo as especificações técnica, realização de telefonemas e transmissão de e-mails para o follow-up de pedidos. Um dos auxiliares encarrega-se ainda da emissão de pedidos de compra para itens comerciais (parafusos, porcas e outros itens que já possuem fornecedores cativos e não demandam mais negociações de compra).

Aos almoxarifes são delegadas as responsabilidades de recebimento de materiais, armazenagem e expedição dos produtos. O almoxarifado da empresa subdivide-se em ‘almoxarifado produtivo' e 'almoxarifado não-produtivo'. No almoxarifado produtivo são

\footnotetext{
${ }^{2} \mathrm{O}$ termo follow-up neste caso refere-se aos contatos realizados pelos compradores para verificar se os prazos acordados com o fornecedor serão cumpridos.
} 
armazenados todos os materiais de aplicação direta no produto (componentes fundidos, barras, chapas, juntas de vedação, parafusos etc); já no almoxarifado não-produtivo são armazenados os materiais de consumo (lixas e abrasivos, componentes para manutenção de máquinas, modelos de fundição, produtos de limpeza, lubrificantes e tintas).

As principais dificuldades verificadas no departamento de suprimentos são a obtenção de menores prazos de entrega junto aos fornecedores a fim de atender prazos extremamente curtos repassados do departamento de vendas pelo PCP; o controle do estoque mantendo atualizado o registro das entradas e saídas de materiais, assim como o acionamento dos pontos de reposição de materiais quando atingido o estoque mínimo, evitando a falta repentina de materiais; a negociação com baixos volumes de compra; a existência de itens com longo leadtime de fornecimento - quarenta dias em média para o caso dos componentes especiais de fundição; a falta de uma programação de compras sistemática passada com antecedência pelo PCP.

O nível de escolaridade dos funcionários da área administrativa e o tempo de atuação na empresa são apresentados no quadro 5. 


\begin{tabular}{|c|c|c|c|c|}
\hline Departamento & Função & Formação escolar & $\begin{array}{l}\text { Tempo na } \\
\text { empresa }\end{array}$ & Observação \\
\hline \multirow{9}{*}{ Vendas } & Gerente & Engenheiro Elétrico & 8 anos & $\begin{array}{l}13 \text { anos de experiência } \\
\text { anterior na multinacional }\end{array}$ \\
\hline & Analista 1 & Nível médio & 10 anos & -- \\
\hline & Analista 2 & Nível médio & 2 anos & $\begin{array}{c}\text { ex-auxiliar de vendas na } \\
\text { multinacional }\end{array}$ \\
\hline & Analista 3 & Comércio Exterior & 1 ano e 6 meses & $\begin{array}{c}\text { Em tempo parcial na } \\
\text { empresa }\end{array}$ \\
\hline & $\begin{array}{l}\text { Auxiliar de } \\
\text { Marketing }\end{array}$ & Nível médio & 6 anos & -- \\
\hline & Vendedor externo 1 & Nível médio & 1 ano e 3 meses & \multirow{2}{*}{$\begin{array}{c}\text { Experiência técnica } \\
\text { adquirida em revendas }\end{array}$} \\
\hline & Vendedor externo 2 & Nível médio & 1 ano & \\
\hline & Vendedor externo 3 & $\begin{array}{l}\text { Engenheiro } \\
\text { Mecânico }\end{array}$ & 1 ano e 4 meses & -- \\
\hline & Estagiário & $\begin{array}{l}\text { Engenheiro } \\
\text { Mecânico }\end{array}$ & 6 meses & -- \\
\hline Financeiro & Assistente & Administração & 4 anos & -- \\
\hline \multirow{2}{*}{$\begin{array}{l}\text { Recursos } \\
\text { Humanos }\end{array}$} & Gerente & Administração & 10 anos & -- \\
\hline & Assistente & Nível médio & 5 anos & -- \\
\hline \multirow{8}{*}{ Suprimentos } & Gerente & Nível médio & 8 anos & $\begin{array}{l}\text { Experiência anterior } \\
\text { como empresário }\end{array}$ \\
\hline & Comprador 1 & Nível médio & 3 anos & $\begin{array}{c}\text { Experiência anterior } \\
\text { como comprador na } \\
\text { multinacional }\end{array}$ \\
\hline & Comprador 2 & Administração & 3 meses & -- \\
\hline & Auxiliar 1 & \multirow{5}{*}{ Nível médio } & 1 ano & -- \\
\hline & Auxiliar 2 & & 7 meses & -- \\
\hline & Almoxarife 1 & & 1 ano e 2 meses & -- \\
\hline & Almoxarife 2 & & 1 ano & -- \\
\hline & Almoxarife 3 & & 3 meses & -- \\
\hline
\end{tabular}

Quadro 5: Funcionários da área administrativa - escolaridade e tempo de atuação na empresa

\subsubsection{DESCRIÇÃO DA ÁREA INDUSTRIAL}

A área industrial da empresa compreende os departamentos de Engenharia/Projeto, PCP, Controle de Qualidade e Fábrica. 


\section{a) Departamento de Engenharia/Projeto}

Ao departamento de Engenharia/Projeto cabem as especificações de fabricação do produto (material, dimensional, características construtivas e de montagem do produto final). Este departamento conta com apenas um funcionário direto, que se reporta hierarquicamente ao gerente industrial; porém o projeto do produto é realizado em conjunto com o dirigenteproprietário da empresa, o qual detém os conhecimentos referentes à aplicação e funcionamento dos produtos, realizando os cálculos e dimensionamentos necessários para a confecção do produto e seus componentes.

A principal meta deste departamento é manter atualizado o conjunto de informações necessárias para fabricação, transmitindo tais informações para os setores pertinentes por meio de desenhos técnicos e especificações complementares quando necessárias. Para tanto, o projetista realiza suas atividades utilizando essencialmente um aplicativo de desenho computacional CAD (Computer Aided Design).

\section{b) Departamento de PCP}

Ao departamento de Planejamento e Controle de Produção (PCP) cabem as responsabilidades referentes à Programação, Planejamento e Controle das atividades de produção da empresa. Para tanto, este departamento conta em maio de 2007 com uma equipe de três funcionários, sendo um supervisor de PCP (cargo desempenhado pelo pesquisador na empresa), um estagiário da área de Engenharia de Produção e um auxiliar que começou a ser treinado em março para dar suporte às atividades do departamento.

As principais metas deste departamento são atender os prazos de entrega assumidos com os clientes, controlar o fluxo de materiais dentro da fábrica e administrar o processo de fabricação ajudando a manter a organização da fábrica e os níveis de refugo e re-trabalho dentro dos limites estabelecidos. 
Ao supervisor de PCP cabem as responsabilidades de fazer o acompanhamento da carteira de pedidos; planejar a compra de materiais; transmitir as informações necessárias para a emissão das notas fiscais; programar os trabalhos nas máquinas de comando numérico (CNC) e os trabalhos diários de produção a fim de priorizar a entrega de pedidos específicos. A ele, cabe ainda a responsabilidade de compartilhar com o dirigente as funções anteriormente desempenhadas pelo gerente industrial, que foi desligado da empresa em maio de 2005. Essas atividades são relacionadas à resolução de conflitos e problemas pontuais com funcionários da área industrial, coordenação e monitoramento dos trabalhos na fábrica e responsabilidades referentes à manutenção do Sistema de Gestão da Qualidade (SGQ), além da resolução de problemas em conjunto com os responsáveis dos demais departamentos.

O estagiário do PCP foi contratado em dezembro de 2006 e está cursando Engenharia de Produção Mecânica. Assim como foi o caso do supervisor de PCP, recorreu-se à contratação de um estagiário como forma de preparar um funcionário capacitado para a resolução de problemas relacionados à área produtiva da empresa. Foram atribuídas a ele as atividades de abertura e fechamento de ordens de produção e de apontamento dos índices de refugo e re-trabalho registrados no processo de fabricação; a organização e arquivamento destas ordens; o levantamento de tempos de fabricação, para posteriores comparações com a composição dos custos atuais dos produtos e melhoria na programação da produção.

$\mathrm{O}$ auxiliar de PCP está sendo treinado para dar suporte às atividades do departamento (confecção da lista diária de produção, geração de solicitações de compras, abertura de ordens de produção, verificação de faltas de materiais e auxílio nas atividades de controle de produção). Este funcionário, já era integrante do quadro da empresa, trabalhava no setor de montagem desde junho de 2005 e, devido ao seu engajamento e interesse, foi transferido para o PCP. Destaque-se, ainda, que ele cursa o primeiro ano de Engenharia de Produção, possuindo ainda formação técnica na área de mecânico de usinagem. 
As principais dificuldades do PCP estão relacionadas a atender prazos de entrega curtos; conviver com as constantes mudanças de prioridade (falta de foco), que exigem a reprogramação das atividades produtivas; contornar as limitações de capacidade por meio do uso de horas extras (exigindo a permanência de funcionários após o horário de expediente) e; evitar quebras de estoque devido à falta repentina de materiais.

\section{c) Departamento de controle de qualidade}

O departamento de controle de qualidade (CQ) encarrega-se das atividades de inspeção de materiais; da confecção e emissão de certificados de teste e qualidade do produto; do acompanhamento das atividades produtivas a fim de garantir sua realização de modo a atender os requisitos estabelecidos em projeto; de gerar relatórios de acompanhamento das atividades operacionais; da manutenção de contatos com fornecedores solicitando a correção de problemas identificados no recebimento de materiais e da manutenção de rotinas internas necessárias para a manutenção do SGQ referentes à certificação ISO 9001:2000 obtida em outubro de 2005 .

Este departamento conta com dois inspetores de qualidade, os quais reportam-se hierarquicamente ao dirigente-proprietário da empresa. Um dos inspetores é responsável pelas atividades administrativas referentes à manutenção do SGQ, pelo contato com fornecedores, pela confecção dos certificados de teste e qualidade do produto, pelo acompanhamento e retorno às reclamações de clientes. Ao outro inspetor cabem as atividades de inspeção de recebimento, durante a produção e inspeção final dos produtos, assim como; a segregação dos materiais com problemas de qualidade (sejam eles para re-trabalho ou refugo).

As principais dificuldades verificadas no CQ estão relacionadas à sobrecarga dos trabalhos de inspeção, devido ao fato de que ainda não há uma parceria explícita e formal tanto com funcionários, quanto com fornecedores externos no sentido de se estabelecer um nível de qualidade garantida e uma consciência de modo a monitorarem seus próprios 
resultados já segregando os materiais não-conformes; às necessidades de liberação de matérias-primas com necessidade de correção posterior no processo de produção, devido à impossibilidade de se aguardar a reposição do material por parte do fornecedor, ocasionando maior tempo de fabricação e conseqüentemente maior custo; às dificuldades com fornecedores para devolução de peças defeituosas, devido ao baixo volume e também à justificativa por parte do fornecedor de que o problema foi ocasionado devido à pressa da empresa, obrigando-o a acelerar seu processo de fabricação e, em algumas circunstâncias, a problemas no projeto do produto dificultando a confecção dos itens fornecidos.

O quadro 6 apresenta o nível de escolaridade e tempo de atuação na empresa dos funcionários dos departamentos da área industrial descritos anteriormente.

\begin{tabular}{|c|c|c|c|c|}
\hline Departamento & Função & Formação escolar & $\begin{array}{l}\text { Tempo na } \\
\text { empresa }\end{array}$ & $\overline{\text { Observação }}$ \\
\hline $\begin{array}{c}\text { Engenharia/ } \\
\text { Projeto }\end{array}$ & Projetista & Nível médio & 4 anos & $\begin{array}{c}\text { Cursos técnicos } \\
\text { específicos de desenho }\end{array}$ \\
\hline \multirow{3}{*}{ PCP } & Supervisor & $\begin{array}{l}\text { Engenheiro de } \\
\text { Produção }\end{array}$ & 3 anos e 5 meses & Pesquisador \\
\hline & Estagiário & $\begin{array}{l}\text { Engenheiro de } \\
\text { Produção }\end{array}$ & 6 meses & -- \\
\hline & Assistente & Nível médio & 2 anos & -- \\
\hline \multirow{2}{*}{$\begin{array}{l}\text { Controle de } \\
\text { Qualidade }\end{array}$} & Inspetor & Administração & 3 anos e 4 meses & -- \\
\hline & Inspetor & Nível médio & 3 meses & -- \\
\hline
\end{tabular}

Quadro 6: Funcionários da área industrial - escolaridade e tempo de atuação na empresa

\section{d) Fábrica}

À Fábrica cabem as atividades de confecção do produto e seus componentes. Para tanto ela encontra-se subdividida em setor de montagem, fabricação com máquinas convencionais, fabricação com máquinas $\mathrm{CNC}$ e setor de acabamento (pintura, solda e rebarbação).

A estrutura hierárquica da fábrica encontra-se formada por um supervisor geral, que comanda os líderes de montagem, $\mathrm{CNC}$, do setor de acabamento e os demais operadores das 
máquinas convencionais. Sob o comando dos líderes, estão os funcionários de cada setor específico (montagem, CNC e acabamento).

O processo de fabricação da empresa é composto por seis tornos convencionais, sete furadeiras (dos tipos de coluna, bancada e radial), uma fresadora universal, uma retificadora vertical, uma lapidadora, quarto tornos $\mathrm{CNC}$, um centro de usinagem $\mathrm{CNC}$, duas prensas excêntricas, três prensas hidráulicas, uma serra de fita industrial, três máquinas de solda (TIG, MIG e Oxiacetileno), uma caldeira para geração de vapor, bancadas para montagem e testes dos produtos, uma cabine de pintura industrial, entre outros equipamentos de menor porte para o suporte às atividades desenvolvidas.

O nível de escolaridade predominante entre os funcionários é o nível médio associado à realização do curso técnico de mecânico de usinagem do SENAI. Os líderes são funcionários que detêm maior conhecimento nos setores onde atuam, nos quais se busca aprimorar a capacidade de coordenar um grupo de pessoas e canalizar o conjunto de informações para realização dos trabalhos diários de produção (via lista diária de produção originada diariamente pelo PCP).

O supervisor da fábrica possui formação técnica na área de usinagem e experiência de mais de trinta anos em processos de usinagem. Ele, já trabalhou na multinacional concorrente e, por esse motivo, possui um vasto conhecimento da linha de produtos da empresa objeto de estudo, contando ainda com conhecimentos sobre a aplicação e os processos de sua fabricação.

As principais dificuldades da fábrica estão relacionadas ao uso de alguns equipamentos obsoletos, os quais limitam determinadas operações do processo de fabricação; a sobrecarga de trabalho em alguns centros de trabalho; a limitações de capacidade por conta da escassez de mão-de-obra e às constantes mudanças de programação da produção. 


\section{APRESENTAÇÃO, ANÁLISE E INTERPRETAÇÃO DOS DADOS}

O propósito deste capítulo é apresentar, analisar e interpretar os dados obtidos durante o trabalho de campo à luz da revisão bibliográfica apresentada nos capítulos 2, 3 e 4.

\subsection{PROCESSOS DE ORGANIZAÇÃO INTERNA E MUDANÇA NA PRODUÇÃO}

Diversos acontecimentos e fatos foram registrados desde o início das atividades na empresa, os quais se encontram apontados no diário de campo. Muitos deles podem ser listados como processos de mudança e organização interna da empresa, ou seja, representaram um conjunto de atividades em busca da sistematização e adequação das práticas realizadas na empresa de modo a criar uma rotina de trabalho e meios de comunicação eficazes. Esses processos foram embasados em uma lógica de funcionamento para a organização da empresa, seja ela com base no conhecimento dos integrantes do quadro de funcionários, em literatura disponível, seja, ainda, em práticas realizadas em outras empresas.

Por isso, são apontados e descritos, nas seções seguintes, os acontecimentos e fatos mais relevantes relacionados ao tema deste trabalho.

\subsubsection{ESTRUTURAÇÃO DAS ATIVIDADES DO PCP}

A estruturação das atividades de PCP foi impulsionada com a implantação do sistema informatizado de gestão e pela urgência de melhorar a gestão operacional da produção. $\mathrm{Na}$ primeira etapa de implantação do sistema, foram cadastrados todos os produtos, componentes 
e demais materiais utilizados na empresa (produtivos e de consumo). Nesta etapa, foram cadastrados por volta de 3500 produtos finais e 7000 materiais (componentes do produto, matérias-primas e materiais de consumo).

A partir de então, iniciou-se a confecção da estrutura dos produtos, com a definição dos itens pais e filhos, assim como das matérias-primas para os componentes do produto. Essas informações foram obtidas nos desenhos técnicos disponíveis na empresa e junto aos funcionários, os quais, em muitos dos casos, eram os únicos detentores de algumas informações relevantes e atualizadas sobre o produto e aspectos referentes à sua fabricação e montagem.

Outra etapa da implantação e levantamento de informações para a estruturação do PCP foi o cadastro dos processos de fabricação dos componentes e do produto no sistema informatizado. Para realizar essa etapa, foi necessária a permanência no chão-de-fábrica percorrendo o processo de fabricação e apontando as informações necessárias para montar os fluxos do processo de fabricação.

Concluídas as duas etapas anteriores, cadastro de materiais e do processo de fabricação, deu-se início à geração e ajustes das ordens de produção (OP). Dentro da sistemática estabelecida para a realização do PCP, a OP é o documento que aciona a produção tendo como informação de entrada as necessidades transmitidas pelo departamento de vendas e/ou as baixas de estoque. A OP, também, é o documento no qual são realizados os apontamentos de produção (quem executou a operação, quando, em que máquina, se houve refugo, re-trabalho e seus motivos, o status de inspeção), servindo ainda como documento que aciona as baixas de materiais no estoque.

Todo o processo de geração e uso das ordens de produção levou por volta de dez meses, tendo em vista a necessidade de treinar funcionários, conscientizá-los da necessidade de realizar os apontamentos, conscientizar os integrantes da empresa de que a 'coisa' mudou e 
que, via de regra, a partir da sistemática definida e implantada para a programação e controle de produção via OP, não daria mais para sair com uma peça 'debaixo do braço' do almoxarifado sem gerar registro no estoque e sem a existência de uma OP.

Em virtude do conjunto de informações disponíveis para o PCP neste ponto, foi possível iniciar, via sistema informatizado, o planejamento da compra de materiais. Tal planejamento envolve a identificação das necessidades de compra de materiais, tendo em vista a carteira de pedidos (relatórios gerenciais obtidos do sistema informatizado) e a posição dos estoques. Na medida em que é identificada a necessidade de compra, uma solicitação de compra (SC) é emitida pelo PCP e transmitida para o departamento de suprimentos para que o material necessário seja providenciado.

Destaque importante relacionado ao planejamento de materiais é o fato de que as compras são acionadas principalmente em virtude das vendas concretas realizadas e das baixas de estoque, não havendo ainda uma sistemática de compras definida com base em uma política de estoques ou em uma previsão futura de demanda. Isso ocasiona muitas quebras de estoque e, em algumas circunstâncias, a realização de compras mal dimensionadas.

Outra atividade que passou a ser atribuição do PCP foi a organização das informações da carteira de pedidos para posterior programação dos serviços na fábrica, a definição e transmissão de prazos de entrega para o departamento de vendas.

Por fim, destaca-se que, para a estruturação das atividades do PCP, foram necessários a contratação e o treinamento de mão-de-obra para viabilizar a execução desse conjunto de atividades, que anteriormente eram realizadas de maneira fragmentada nos demais departamentos e que, a partir de então, foram atribuídas ao PCP. 


\subsubsection{PROCESSO DE CERTIFICAÇÃO ISO 9001:2000}

Como já destacado anteriormente, a partir de meados de 2003 iniciaram-se os esforços para a obtenção da certificação ISO 9000. A norma base para o processo de certificação foi a NBR ISO 9001 versão 2000, a qual envolve o atendimento de requisitos e a padronização das atividades de projeto e desenvolvimento de produtos, fabricação, aquisição de insumos e comercialização do produto.

A fim de atender os requisitos da norma, foi necessária a geração de documentos pertinentes às atividades realizadas na empresa, os quais, para o caso da área industrial, foram: instruções técnicas e de trabalho, fluxogramas de processos, plano de manutenção preventiva dos equipamentos, relatórios de manutenção corretiva, quadro de preservação do produto e etiquetas para a identificação do status das peças em processo (material aprovado, reprovado e pendente).

Outros documentos gerados que são utilizados na área industrial são os relatórios de solução de problemas, relatórios de melhoria contínua e relatórios de ação corretiva e preventiva do departamento de controle de qualidade. Destaque-se que, nos demais departamentos da empresa, também foram gerados os demais documentos pertinentes às atividades realizadas, assim como foram documentadas todas as rotinas e procedimentos de cada área, com a geração dos respectivos registros.

$\mathrm{Na}$ fábrica foi necessária, ainda, a definição de áreas identificadas por meio de pintura diferenciada de palets: verdes para a colocação de peças aprovadas; amarelos para peças pendentes, as quais demandam algum re-trabalho, avaliação ou correção; vermelhos para materiais reprovados, seja por falha interna, seja devido a problemas com a matéria-prima.

Após toda a preparação da empresa envolvendo o levantamento de informações para a confecção dos procedimentos e demais documentos necessários, o treinamento de funcionários, a revisão da documentação já existente e das práticas realizadas para a 
fabricação, montagem e testes do produto, foi selecionado e contatado um órgão certificador para solicitar-se a auditoria para a certificação da empresa. Todo esse processo levou por volta de 24 meses, e em outubro de 2005 foi obtida a certificação almejada.

\subsubsection{ORGANIZAÇÃO DO CHÃO-DE-FÁBRICA}

Além da criação de documentos para a sistematização das informações necessárias para a fabricação dos componentes e produtos da empresa, da definição de áreas específicas para a colocação de peças na fábrica, da revisão e criação de documentos técnicos de fabricação, foi necessário ainda melhorar os meios de comunicação com o chão-de-fábrica, dividir autoridade e responsabilidades e realizar melhorias no lay-out produtivo.

No que diz respeito à melhoria nos meios de comunicação com o chão-de-fábrica, buscou-se desenvolver algo que complementasse as informações contidas nas ordens de produção e fizesse a interligação entre as prioridades de entrega transmitidas pelo departamento de vendas, os materiais necessários para a reposição de estoque de produto acabado e componentes e a programação diária de produção. Dessa forma, foi criada uma lista impressa única para os setores de usinagem convencional, montagem, acabamento final e almoxarifado, trazendo as prioridades diárias de produção. Com esse documento único, todos são informados sobre quais produtos devem ser fabricados, quantos, para qual cliente e qual a transportadora (devido aos horários diferenciados de coleta). Essa lista abrange um período de dois a três dias de fabricação e traz também informações complementares sobre o produto (customizações específicas para determinados clientes entre outras). Tal meio de comunicação foi criado para substituir o excessivo uso de comunicações verbais e informais existentes antes na empresa, as quais eram rotineiramente esquecidas, ficavam sob o domínio de poucos e, na grande maioria das vezes, eram imprecisas e incompletas. 
Para o caso do setor de máquinas $\mathrm{CNC}$, foi criado um meio de comunicação diferenciado, pois as máquinas trabalham em dois turnos e possuem ciclos mais longos de fabricação. Neste caso, foi criado um diagrama de 'Programação de Serviços', uma espécie de gráfico de $\mathrm{Gantt}^{3}$ no qual é programada a seqüência de operações, são especificadas as peças a serem fabricadas e o tamanho dos lotes.

Para o caso da divisão de autoridade e responsabilidades no chão-de-fábrica, foram definidos líderes para os setores da fábrica aos quais são transmitidas as informações necessárias para a coordenação das atividades produtivas por meio de reuniões e cópia da lista diária de produção, ficando sob a responsabilidade deles a distribuição de tarefas e o comando dos funcionários de seu setor. Isso foi necessário a fim de se evitar a excessiva centralização de autoridade e informações e melhorar o controle nos setores da fábrica. O organograma apresentado na figura 5, página 83, já traz essa nova configuração de comando implantada na empresa.

As melhorias realizadas no lay-out produtivo foram devidas à aquisição de novas máquinas, à necessidade de reduzir a movimentação de peças durante o processo de fabricação e, em alguns casos, por sugestão dos próprios operadores a fim de melhorar as condições de trabalho para algumas operações. Tais melhorias envolveram a movimentação física de algumas máquinas, por exemplo, o posicionamento de tornos a $45^{\circ}$, a aproximação de máquinas a fim de possibilitar que um único funcionário opere duas máquinas simultaneamente; mudanças nas instalações elétricas e pneumáticas; colocação de proteções nas máquinas e mantas de borracha nas bancadas de trabalho entre outras mudanças que buscaram aumentar a produtividade e a criação de um ambiente de trabalho mais seguro.

\footnotetext{
${ }^{3}$ Gráfico de Gantt é uma ferramenta visual utilizada na programação de atividades, com o objetivo de estabelecer uma seqüência de eventos escalonados no tempo e distribuídos de acordo com os recursos disponíveis.
} 


\subsection{CONSTATAÇÕES SOBRE AS ESPECIFICIDADES DA PEQUENA EMPRESA}

Muitas das afirmações colocadas na literatura sobre a pequena empresa e sua gestão puderam ser confirmadas no caso aqui estudado. No departamento de vendas, constatou-se a limitada força de penetração no mercado da empresa de pequeno porte, seja pela falta de recursos para expor ao mercado seus produtos (marketing), seja por conta da concorrência desigual com empresas de maior porte. A alternativa encontrada para contornar tais limitações foi o estabelecimento de parcerias com revendas e empresas de manutenção a fim de possibilitar o maior acesso aos clientes finais, sendo o estabelecimento de parcerias uma das alternativas já destacadas na literatura como forma de inserção da pequena empresa na estrutura produtiva.

No departamento de suprimentos, foram detectadas dificuldades relacionadas à baixa expressividade da pequena empresa junto aos fornecedores, principalmente devido ao seu reduzido volume de compras, tendo esta que se sujeitar aos preços impostos por tais fornecedores e às condições comerciais disponíveis, além da impossibilidade de se efetuar compras diretamente de fabricantes. Este fato afeta a lucratividade do empreendimento devido à composição do custo final do produto, resultando também em reflexos nos seus prazos de entrega determinados em função de suas opções de fornecimento de insumos.

Estes dois casos, departamentos de vendas e suprimentos, são exemplos das especificidades ambientais, as quais dizem respeito à inter-relação da empresa com seu ambiente.

No departamento financeiro, observou-se a limitação de recursos financeiros de curto prazo para a operação do negócio, limitação que pode ter origens diversas, entre elas: falta de recursos disponíveis quando da abertura do empreendimento para manutenção de caixa; falta de critérios administrativos na gestão dos recursos quando disponíveis; estreita parcela de lucro gerada na venda do produto final em virtude da necessidade vender a um preço baixo 
para enfrentar a concorrência e comprar no preço disponível no mercado devido ao baixo volume de compra (efeito sanduíche). No caso estudado, a forma encontrada para lidar com a insuficiência de recursos em caixa foi o desconto antecipado de duplicatas referentes às vendas realizadas a prazo, resolvendo o problema apenas no curto prazo.

No departamento de Recursos Humanos foram observadas dificuldades referentes à gestão de pessoal, constatadas com a elevada rotatividade de funcionários na empresa, seja ela ocasionada pelas oscilações das vendas obrigando a redução do quadro de funcionários, seja pelo assédio de empresas que oferecem melhores condições de trabalho e remuneração. A análise dos dados sobre a rotatividade de funcionários resulta em uma taxa de $33 \%$ ao ano, ou seja, em média a empresa renova 1/3 do seu quadro de funcionários a cada ano.

$\mathrm{Na}$ diretoria foi possível notar, a partir do histórico de crescimento da empresa, a necessidade de profissionalização do empreendimento, solucionada a partir da contratação de funcionários qualificados para dividirem com o dirigente-proprietário as atividades necessárias para a condução do empreendimento. Atividades estas que, de início, podiam ser conduzidas pelo proprietário sem a necessidade de mecanismos formais de gestão e distribuição de autoridade e responsabilidades para outras pessoas (centralização).

$\mathrm{Na}$ área industrial, as principais constatações estão relacionadas às dificuldades relacionadas à centralização de poder e decisões encontrada no início das atividades na empresa, à extração do conhecimento e de informações dos funcionários mais experientes, que as detinham em suas cabeças (pessoalidade); à formalização dos procedimentos e atividades operacionais até então realizados com excessiva informalidade e sem a alocação de responsabilidades.

Com relação à centralização de poder, buscou-se criar novos postos de comando por meio da nomeação de lideres e do estabelecimento claro do escopo de atuação dos supervisores, os quais, além da autoridade estabelecida, passaram a ter responsabilidades 
sobre a consecução das metas. Isso resultou na necessidade de maior comunicação e comprometimento entre os supervisores e lideres da área industrial a fim de resolver problemas em conjunto, evitando-se a necessidade de atuação direta do dirigente-proprietário na resolução de problemas operacionais.

A extração do conhecimento e de informações dos funcionários mais experientes foi necessária para documentar e formalizar as atividades realizadas pelos funcionários para a confecção e testes dos produtos, assim como para gerar uma base de conhecimento que se perpetue na empresa e possibilite o treinamento de novos funcionários de modo impessoal. $\mathrm{Na}$ literatura, esse aspecto esta relacionado ao alto nível de pessoalidade e informalidade existente nos empreendimentos de pequeno porte, nos quais há uma predominância de comunicações verbais e relações pessoais entre os indivíduos, o que dificulta a gestão do conhecimento e a difusão da informação.

Quanto às especificidades estruturais, constatou-se, em relação à complexidade da estrutura organizacional, que já há um avançado nível de subdivisão de tarefas, existem departamentos definidos e predominam alguns níveis hierárquicos. Com relação à formalização, observou-se que foram dados alguns passos iniciais rumo à construção de normas e procedimentos, fomentados pelo processo de certificação ISO 9000. A centralização está sendo vencida aos poucos à medida que as pessoas se tornam mais comprometidas e conhecedoras de suas responsabilidades, mais capazes de tomarem decisões fundamentadas e ajudarem na consecução das metas organizacionais.

No que diz respeito às especificidades estratégicas, observa-se na empresa objeto de estudo que não são utilizadas técnicas formais de planejamento, sendo este realizado de maneira informal, não por desconhecimento das técnicas, mas sim por falta de dedicação de um tempo exclusivo para o planejamento. Da mesma forma, não são realizadas sistematicamente análises para a construção de uma visão interna e externa da empresa, o 
processo estratégico é bastante informal e as responsabilidades sobre tal planejamento concentram-se principalmente no dirigente, assim como são dele as responsabilidades de alocação de recursos e transmissão das metas principais do negócio para os responsáveis das áreas.

Uma possível justificativa para essa forma de se conduzir o planejamento estratégico na pequena empresa pode ser encontrada na afirmação de Golde (1986, p.11), ao destacar que "para a pequena empresa planificar significa manipular enormes incertezas sobre as quais ela parece ter pouco controle". Desta forma, tornam-se mais viáveis para a sobrevivência diária o envolvimento e a dedicação de tempo para se resolver os problemas enfrentados no presente, restringindo-se sempre o tempo para se dedicar às questões futuras que possam afetar o empreendimento.

Em relação às especificidades tecnológicas, constatou-se que na empresa estudada as tecnologias estão compatíveis com suas necessidades. Apenas no chão-de-fábrica, existem algumas máquinas obsoletas, que limitam algumas atividades produtivas, principalmente quando da fabricação de peças especiais de grande porte; porém, quando necessário, são contratados serviços terceirizados.

Quanto às especificidades decisionais, observou-se que na empresa predominam ainda decisões operacionais, individuais e de certo modo intuitivas, apesar de serem tomadas à medida que surgem necessidades concretas. Destaque-se, porém, à proporção que a empresa cresce e se profissionaliza, as decisões vão tomando características mais estratégicas, com o envolvimento das demais pessoas (coletividade), e tendem a ser mais racionais; o dirigente, aos poucos, se vê obrigado a delegar o poder de decisão para outras pessoas a fim de manter o funcionamento do empreendimento.

As especificidades comportamentais, que estão relacionadas ao comportamento do dirigente, puderam ser notadas na empresa objeto de estudo a partir da transmissão do perfil, 
atitudes, desejos, competências e experiências do dirigente para a gestão da empresa. Este, por possuir um perfil extremamente técnico procurava que os demais membros da empresa também agissem da mesma forma e, além disso, muitas vezes limitava a busca de soluções pelos envolvidos ao dar soluções prontas para os problemas emergentes.

O perfil do dirigente da empresa aproxima-se mais do que Filion (1999) classificou como empreendedor, tendo em vista a sua vocação que o acompanha desde outros empreendimentos e sua busca em projetar uma estrutura organizacional para suportar e manter o funcionamento organizacional.

Na empresa observou-se, também, um forte envolvimento pessoal entre o dirigente e os funcionários, muitos dos quais o acompanham desde outros empreendimentos ou da fundação da empresa. Outro fato já comentado na literatura e que ocorre no caso estudado é o envolvimento familiar: seis dos funcionários da empresa mantêm relações de parentesco com o proprietário (três filhos, uma sobrinha, uma nora e o sogro de uma filha).

Outro aspecto constatado no estudo de caso realizado foi a contratação de consultorias externas como forma de buscar soluções para deficiências na gestão do empreendimento. Regularmente atuam na empresa três consultores externos (qualidade, financeiro e sistema informatizado), fora outros que realizaram trabalhos pontuais e de curta duração. Ainda, encontram-se terceirizados os serviços de portaria, assessoria em higiene e segurança do trabalho, assessoria jurídica e fiscal e as manutenções da área de informática.

\subsection{PLANEJAMENTO ESTRATÉGICO E OPERACIONAL NA EMPRESA}

$\mathrm{Na}$ literatura são encontrados indícios e afirmações de que na pequena empresa o planejamento estratégico é realizado de modo informal e não sistemático. Alguns autores vão até mais longe afirmando que nela não há planejamento estratégico. O fato de o planejamento estratégico ser realizado de modo informal e não sistemático pôde ser constatado no caso 
estudado, porém não é possível afirmar a inexistência de estratégia, pois em algumas ações e decisões tomadas na empresa objeto de estudo é perfeitamente possível identificar um cunho estratégico (visão de longo prazo e decisões que afetam todo o empreendimento), mesmo que o processo que levou a tais ações e decisões não tenha sido guiado por um conjunto de passos planejados e programados, envolvendo a participação e a comunicação aos demais membros da empresa.

Exemplos dessas ações e decisões foram verificados na busca de parcerias para a venda dos produtos e na contratação de funcionários qualificados e experientes para assumir postos de trabalho importantes na estrutura da empresa - alguns desses funcionários com experiência adquirida na concorrência. Tais constatações reforçam a idéia de estratégia emergente apresentada na revisão bibliográfica como 'uma estratégia essencialmente não planejada, uma linha de ação que só é percebida como estratégica pela organização à medida que vai se desenrolando ou até mesmo depois que já aconteceu e pode ser tomada como um padrão de ação'.

Desta forma, é possível afirmar que no caso estudado o processo de planejamento assume características da emersão, ocorre de maneira informal, não há uma política de planejamento explícita e não há uma cadeia de objetivos formalmente estabelecida. Os objetivos e metas são definidos no curto prazo e repassados para os responsáveis pelo dirigente-proprietário.

Com relação ao planejamento operacional, focado nesta pesquisa para o caso da produção, constatou-se que ele carece de mais análises e informações que subsidiariam a tomada de decisão. No caso estudado, a previsão de demanda deficiente e dificuldades no estabelecimento de mecanismos de controle e reposição de estoques impactam nas demais atividades pertinentes ao PCP devido à falta de informações em tempo hábil para se programar a compra de materiais e para o planejamento e programação da produção. Isso 
restringe a capacidade da empresa em responder aos prazos de entrega impostos pelos clientes e gera custos extras devido à necessidade de se utilizar horas-extras e compras de emergência para atender necessidades de entrega não programadas.

O planejamento operacional, seja ele relacionado à produção, seja à área financeira, de vendas, de suprimentos, de recursos humanos ou qualidade, é realizado sempre à medida que necessidades concretas são identificadas, limitando-se o tempo para as análises e avaliações de alternativas para as decisões a serem tomadas.

Não há na empresa uma avaliação sistemática de desempenho. Quando ela é realizada, leva em conta a disponibilidade de títulos a serem antecipados em carteira versus contas a serem pagas no período. Desta forma, é avaliado o volume de vendas realizadas a prazo com possibilidade de desconto de títulos em bancos versus contas a vencer no período considerado.

As atividades da administração da produção que são rotineiramente desenvolvidas na empresa são: o projeto de produtos, a administração da cadeia de suprimentos (desenvolvimento de fornecedores e acompanhamento dos já existentes), o planejamento e controle de qualidade, e o planejamento e controle de produção. As demais atividades que compõem o escopo da administração da produção são desenvolvidas apenas quando da necessidade de solução de problemas pontuais, como, o planejamento do layout e fluxo produtivo.

Os critérios competitivos mais valorizados para uma contribuição expressiva da administração da produção para a empresa e seus principais clientes são rapidez, confiabilidade e custo, tendo em vista o fato de que os principais clientes são revendas e empresas de manutenção, que não se dispõem a manter produtos em estoque, mas que, por outro lado, priorizam o atendimento de seus clientes com prazos curtos e com a melhor margem de lucro possível. 
O sistema de produção praticado na empresa pode ser classificado como um misto entre produção seriada para estoque (itens de alta demanda) e produção sob encomenda (itens especiais de baixa demanda). Na sua gestão, emprega-se um sistema informatizado nos moldes de um ERP, que se encontra na etapa de ajustes e integração dos módulos. A opção por implantar um sistema informatizado dessa natureza mostrou-se viável em virtude do elevado número de itens constituintes dos produtos e da possibilidade de se integrar e disponibilizar de maneira mais organizada as informações pertinentes à gestão do empreendimento. Tal sistema tem se mostrado uma ferramenta bastante útil para o planejamento e controle da produção, tendo em vista o fato de que simplifica o cálculo de necessidades de materiais (módulo MRP) e serve para integrar as informações geradas nos departamentos da empresa, como, por exemplo, as informações da carteira de pedidos e o acompanhamento dos processos de compras.

Observou-se que na empresa não são empregados os conceitos e técnicas do JIT e da Produção Enxuta, assim como, também, não são empregados os princípios da Teoria das Restrições.

No que diz respeito às atividades inerentes ao PCP listadas na revisão bibliográfica notou-se:

a) O processo de previsão de vendas/gestão da carteira de pedidos é deficiente, por conta de um perfil variado de demanda dos produtos oferecidos pela empresa, que afeta as decisões sobre o que produzir e comprar antecipadamente;

b) O planejamento agregado de produção não é realizado em virtude do elevado grau de incerteza sobre os rumos futuros do negócio e da indisponibilidade de recursos para se preparar para uma situação futura, que pode não se concretizar; 
c) O planejamento-mestre de produção deriva da atividade diária de faturamento da empresa, pois, ao promover o desconto antecipado de títulos, já são definidos os itens a serem fabricados e seus prazos de entrega;

d) O planejamento das necessidades de materiais é fruto da análise conjunta dos pedidos em carteira e das informações sobre a posição dos estoques. Para o caso dos itens de maior demanda, são colocados pedidos programados junto aos fornecedores para um período de até noventa dias, levando-se em conta o histórico de vendas da empresa;

e) A atividade de controle de estoques é realizada pelo departamento de suprimentos em conjunto com o PCP, e as maiores dificuldades encontradas estão em manter a disciplina de baixas e entradas de materiais no estoque com os registros pertinentes no sistema informatizado;

f) A programação da produção é realizada via diagrama de programação de serviços nas máquinas $\mathrm{CNC}$ e via lista diária de produção para os demais setores da fábrica. Com essa informação em mãos, o supervisor da fábrica e os líderes alocam os trabalhos para os centros produtivos;

g) A atividade de planejamento e controle da capacidade não é realizada antecipadamente, e as flutuações nas necessidades de capacidade são absorvidas por meio do uso de horasextras, diminuição do contingente de pessoal ou terceirização de serviços;

h) O controle de produção é realizado através dos dados apontados nas ordens de produção, com a geração dos índices de refugo e retrabalho para a realização de ações para a solução de problemas, e por meio da atuação direta dos funcionários do PCP junto aos responsáveis na fábrica para que as prioridades diárias sejam cumpridas.

As dificuldades inerentes às atividades do PCP foram verificadas no caso estudado, mostrando-se bastante intensas aquelas relacionadas à previsão de demanda e ao gerenciamento de prazos e prioridades em função das limitações de capacidade. 


\subsection{A DINÂMICA DA PEQUENA EMPRESA ESTUDADA}

O foco deste trabalho foi identificar fatores relacionados ao planejamento operacional da produção, $\mathrm{PCP}$, de um empreendimento metalúrgico de pequeno porte que influenciassem seu desempenho.

Nos trabalhos encontrados na literatura que buscam relacionar planejamento e desempenho, observou-se que a fim de se medir o impacto das ações e forma de realização do planejamento operacional da produção no desempenho empresarial, a métrica mais comum passa pela perspectiva financeira medida pelo volume de vendas das empresas (BERMAN, GORDON e SUSSMAN, 1997; LYLES et al., 1993; RUE e IBRAHIM, 1998; WIJEWARDENA et al., 2004). No estudo aqui realizado, utilizou-se também dessa medida, ou seja, buscou-se verificar as características, mudanças e as condições nas quais o planejamento operacional é realizado e, a partir de então, verificar os seus reflexos no volume de vendas.

A fim de avaliar o desempenho da empresa objeto de estudo, tomou-se o volume de vendas anual de 2002 como sendo a base para análise, atribuindo-lhe um valor 100 em virtude das limitações em se divulgar valores reais e da disponibilidade de dados para análise a partir deste ano. A partir de então, foram calculados em função do valor do ano base os demais volumes de vendas até o ano de 2006. Esses valores são apresentados na tabela 2.

Tabela 2: Volume de vendas da empresa

\begin{tabular}{c|c}
\hline Ano & Volume de vendas \\
\hline 2002 & 100 \\
\hline 2003 & 163 \\
\hline 2004 & 198 \\
\hline 2005 & 210 \\
\hline 2006 & 229 \\
\hline
\end{tabular}


Os valores demonstram um crescimento expressivo do volume de vendas da empresa, que, segundo seu dirigente e dados, registrou taxas de crescimento médio da ordem de $63 \%$ nos anos de 2001 a 2003. Na opinião do dirigente, essa variação do volume de vendas se deve à diversificação da linha de produtos, agregados de maior teor tecnológico, ao acesso a novos clientes e à reestruturação da estratégia de vendas (incremento das parcerias com revendas). Ainda, segundo ele, o que dificultou o crescimento da empresa no ano de 2004, quando comparado aos três anos anteriores, foi uma forte investida da concorrente multinacional, ao promover uma campanha de redução de preços de até $80 \%$ numa linha de produtos em relação à sua linha de produtos tradicional.

Com o intuito de ilustrar a discussão realizada até aqui, apresenta-se na figura 6 um conjunto de fatores e eventos que intervêm no desempenho da empresa estudada. Desta forma, respondendo ao problema de pesquisa, observa-se que os principais fatores que intervêm no desempenho da empresa estudada não estão diretamente relacionados ao planejamento operacional da produção; dizem respeito principalmente à indisponibilidade de recursos financeiros de curto prazo. Os fatores relacionados ao planejamento operacional da produção que impactam no desempenho da empresa são secundários e resumem-se na carência de análises e informações que embasariam as ações e decisões a serem tomadas antecipadamente, como, melhores informações sobre a demanda futura, possibilitando a antecipação das compras (maiores lotes com entregas programadas) e fabricação antecipada dos itens, reduzindo-se os prazos de entrega e tempo de permanência dos títulos já descontados na empresa com conseqüente redução do uso de horas-extras (nivelamento da produção).

Os fatores que levaram a ganhos de desempenho verificados não estão diretamente relacionados ao planejamento operacional da produção (projeto de novos produtos e parcerias com clientes); por isso, deve-se frisar que não foi possível identificar no caso estudado uma 
relação direta entre as ações no planejamento operacional e reflexos no desempenho da empresa com base na métrica adotada.

Os fatores sumarizados na figura 6 demonstram que, devido à falta de recursos para manutenção do fluxo de caixa, a empresa desconta títulos referentes às vendas de seus produtos, pagando juros aos bancos e, conseqüentemente, reduzindo sua margem de lucro; também, pela mesma razão, há a necessidade de gerar mais negócios e para isso são concedidos maiores descontos para motivar a compra por parte dos clientes; em função das limitações de caixa as compras precisam ser reduzidas e, deste modo, as compras são realizadas em pequenos lotes a fim de atender necessidades específicas, o que não gera economias de escala. E ainda, em virtude da emergência dos fatos e eventos de curto prazo, não é dedicada a atenção necessária para o planejamento estratégico, impossibilitando sua integração com o planejamento operacional da produção.

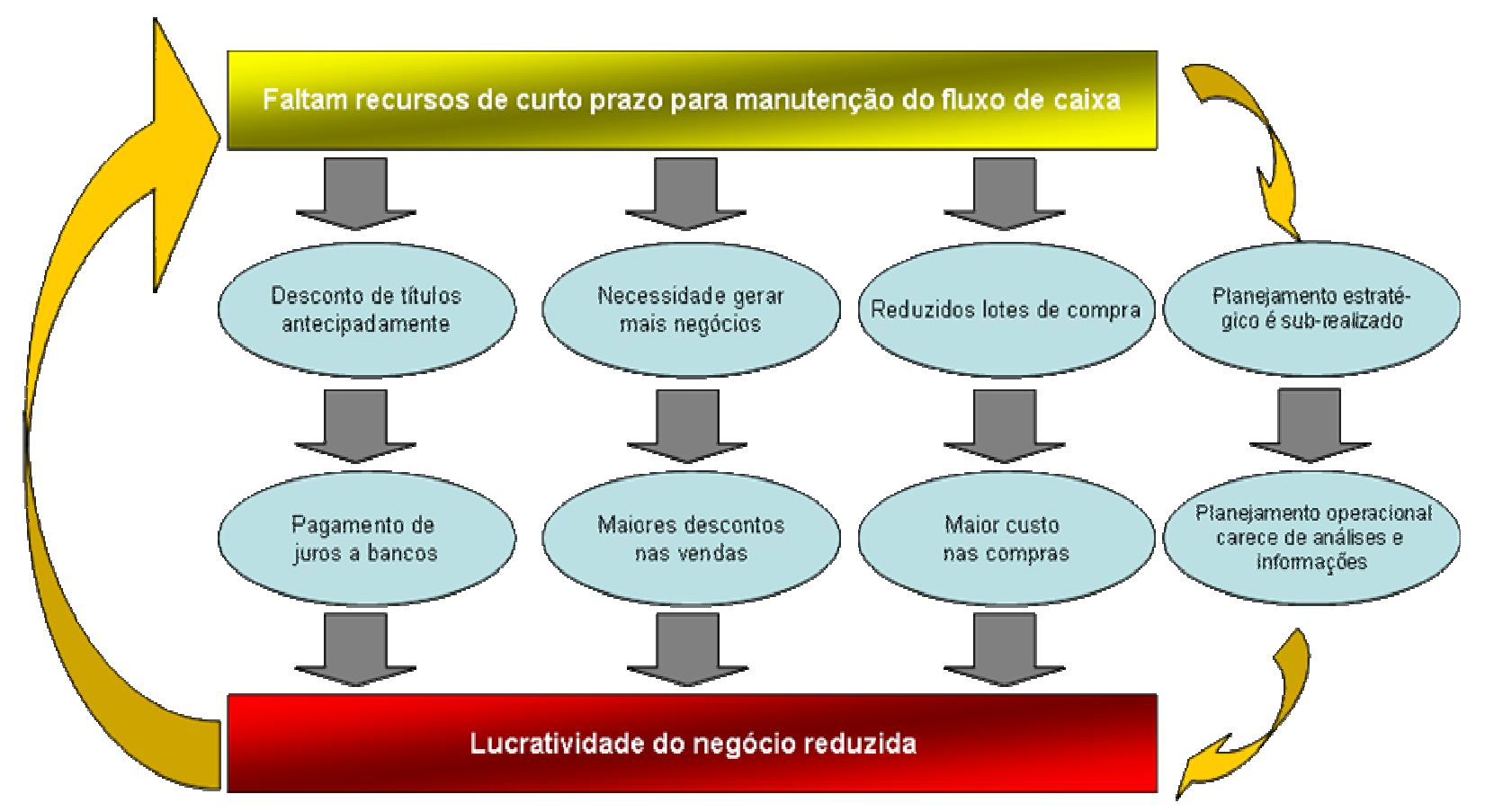

Figura 6: Fatores e eventos que intervêm no desempenho da empresa

Refletindo sobre as questões de pesquisa colocadas, têm-se: 


\section{Quais mudanças organizacionais ocorreram a partir de 2004 com a estruturação do} planejamento e controle da produção?

A estruturação do PCP permitiu a alocação das atividades e responsabilidades pertinentes a este departamento, possibilitando também uma melhor harmonia na transmissão das informações originadas no departamento de vendas, na forma de ordens de produção para a fábrica (permitindo a comunicação dos responsáveis e a programação dos serviços) e na forma de solicitações de compras para o departamento de suprimentos. Além da disponibilização de informações de forma estruturada para os demais setores da empresa, por exemplo, as programações diárias de produção e cronogramas de carregamento de serviços nas máquinas $\mathrm{CNC}$ e as informações sobre prazos de entrega para o departamento de vendas. Verificou-se, também, a gradativa descentralização de poder com a criação de novos postos de comando na fábrica.

2. A maior sofisticação do planejamento operacional - com a sistematização das atividades do PCP - representou melhor desempenho da empresa?

Ocorreu a sistematização das atividades de PCP realizadas na empresa, porém, como já destacado, não é possível associar diretamente tal sistematização aos ganhos ou perdas de desempenho da empresa, pois existem outros fatores que intervêm de maneira significativa no desempenho. Destaque-se, ainda, que as ações de melhoria geradas com a sistematização do planejamento operacional da produção, assim como nos demais setores da empresa, têm reflexos positivos na sua competitividade, como, por exemplo, os esforços para a obtenção da certificação ISO 9000, porém essas melhorias qualificam o empreendimento para se posicionar no mercado, não gerando ganhos diretos em seu desempenho.

3. De que forma as especificidades organizacionais da pequena empresa influenciaram favorável, ou desfavoravelmente, a sistematização do planejamento e controle da produção?

As especificidades da pequena empresa tiveram influências tanto favoráveis quanto desfavoráveis para a estruturação do PCP. Como influências favoráveis destacam-se a sua 
estrutura simples e a facilidade de comunicação existente, aspectos que permitiram um maior dinamismo no processo de sistematização. Já como influências desfavoráveis, podem ser destacadas a limitação de recursos, a carência de bases de informações confiáveis, as decisões e informações essenciais do negócio centralizadas e a excessiva informalidade e pessoalidade enfrentada no início do processo de sistematização do PCP.

\subsection{PLANEJAMENTO, PCP E PEQUENA EMPRESA}

A partir do esboço teórico apresentado na revisão bibliográfica, três grandes conceitos foram fundamentados e destacados: planejamento, PCP e especificidades da pequena empresa.

Os preceitos teóricos conceituam o planejamento como uma prática administrativa capaz de preparar a empresa para o futuro, levando em conta as imposições, demandas e características do ambiente no qual a empresa atua, assim como suas características e capacidades internas. Nas práticas de planejamento, há a segmentação do futuro em longo, médio e curto prazo, e sua interligação é realizada por meio da integração entre os objetivos e metas para cada período considerado via cadeia de objetivos. Há dois tipos principais de planejamento: estratégico (longo prazo) e operacional (médio e curto prazo), resultando em objetivos e metas estratégicos e operacionais, os quais direcionam as ações e servem como parâmetros para controle das atividades e medição de desempenho. Na literatura, reconhecese que nas empresas o processo de planejamento pode ser formal ou informal, porém é ao processo formal que são creditados os maiores benefícios desta prática administrativa.

As observações empíricas demonstraram que, com o crescimento e maior maturidade da empresa, houve a necessidade de se melhorar as atividades de planejamento no empreendimento, porém estas ainda não se encontram da maneira formal apresentada na literatura. Para o caso do planejamento estratégico, observou-se um alto nível de informalidade e pouco tempo de dedicação às atividades direcionadas ao longo prazo devido à 
resolução de problemas imediatos; entretanto, foram identificadas ações de cunho estratégico desenvolvidas que podem ser caracterizadas como resultado de ações emergentes (estratégia emergente).

O PCP é a atividade administrativa dentro da administração da produção responsável por desenvolver o planejamento operacional para a área de produção da empresa. Ele trabalha como os objetivos e metas operacionais derivados do planejamento estratégico e realiza atividades de médio e curto prazo levando em conta, também, considerações sobre qualidade, custo, confiabilidade, velocidade e flexibilidade do sistema de produção. Três principais filosofias e sistemas de produção são apresentados como formas possíveis de se administrar a produção nas organizações, que apresentam técnicas, conceitos e ferramentas respaldadas em seus pressupostos teóricos. Há, ainda, uma estrutura e conjunto de atividades pertinentes ao PCP, as quais visam tratar os dados e informações de entrada para o sistema de produção, transformando-os em dados e informações coerentes para a área produtiva (níveis de estoque a serem mantidos, programação e seqüenciamento das atividades, demanda para os produtos e serviços entre outras).

No caso do PCP, as atividades e observações desenvolvidas na empresa demonstraram a necessidade de maior formalização, principalmente devido ao aumento do número de funcionários, ao aumento do volume de produção, à necessidade de controles mais precisos e à certificação ISO do processo produtivo. Desta forma, foram definidos líderes, os quais orientam os funcionários de seus setores e gerados documentos pertinentes ao processo produtivo da empresa, entre eles: ordens de produção, lista diária de produção, diagrama de programação de serviços para máquinas $\mathrm{CNC}$ e instruções de trabalho. No entanto, faltam diretrizes de longo prazo para o PCP, principalmente devido à não-integração ou inexistência de objetivos e metas de longo prazo explícitos e claros, principalmente pela inexistência de um planejamento sistemático e contínuo. 
As especificidades da pequena empresa são um conjunto de características qualitativas observadas nela, que influenciam de modo significativo a gestão desses empreendimentos e possibilitam uma análise mais abrangente dos fatores que condicionam a forma de sua atuação e gestão, quando comparada à análise realizada apenas com critérios quantitativos (número de funcionários e faixas de faturamento).

As especificidades da pequena empresa foram observadas na empresa e demonstraram-se como fatores influentes e condicionantes da forma de atuação deste porte de empreendimento, demonstrando que devem ser consideradas nos estudos a fim de possibilitar uma caracterização mais adequada da empresa objeto de análise. 


\section{CONSIDERAÇÕES FINAIS}

Este trabalho teve por objetivo "identificar fatores relacionados ao planejamento operacional da produção que intervêm no desempenho de uma pequena empresa metalúrgica”.

O tema da pesquisa foi tratar do planejamento operacional na pequena empresa. $\mathrm{O}$ planejamento é uma ferramenta administrativa que visa à tomada de decisão e à realização de ações antecipadamente, a fim de que objetivos e metas estabelecidos sejam alcançados. Na empresa foi possível observar a não-utilização sistemática do planejamento como forma de guiar as decisões e ações para a consecução de objetivos e metas. O planejamento destaca-se como uma ferramenta administrativa importante, com grandes potencialidades para a obtenção de resultados positivos na pequena empresa, porém verificou-se uma dificuldade de sua adoção devido à resolução constante de problemas imediatos que afetam significativamente o empreendimento.

O planejamento operacional, tratado aqui no âmbito da produção e caracterizado pelo PCP, é a função administrativa responsável por planejar, controlar e transmitir informações para o setor de produção da empresa. Na empresa foi possível acompanhar o processo de estruturação do PCP e a sua formalização, concomitantemente com a implantação de um sistema informatizado de gestão utilizado como ferramenta de apoio para as atividades pertinentes ao PCP. O planejamento operacional da produção mostrou-se como uma função administrativa fundamental para a consecução dos objetivos operacionais da empresa, pois a sua realização de forma sistemática e com base em informações precisas e coerentes pode 
ajudar a empresa a reduzir custos por meio da redução dos níveis de inventário e de melhor dimensionamento das compras, assim como atender o cliente com melhores prazos de entrega.

O processo de planejamento estratégico em sua configuração formal é caracterizado pela definição de objetivos e metas claros, comunicação e participação dos membros da empresa, utilização de técnicas para a avaliação do ambiente empresarial e para o levantamento de informações. Na empresa, não foi observada a existência do planejamento em sua configuração formal - nota-se a existência de estratégia em algumas ações empreendidas, mas estas derivam do planejamento do dirigente, que age em função de sua visão e idéias sobre a empresa, não havendo a comunicação e participação dos demais membros. Tal processo, próprio de elaboração de estratégias, pode ser caracterizado como estratégia emergente em função de um padrão de ações e decisões observadas na empresa. Como o caso do planejamento, a elaboração de estratégias que possam determinar condições futuras favoráveis para a empresa é de grande importância, pois possibilita que ela se prepare para condições futuras de modo a obter um desempenho superior ao de seus concorrentes, criando também caminhos alternativos em função das mudanças no ambiente onde atua.

As especificidades da pequena empresa são características próprias delas e estão relacionadas ao seu ambiente, estrutura, estratégia, tecnologia, decisões e comportamento do dirigente. Na empresa foram identificadas características das especificidades da pequena empresa, que se mostraram como fatores influentes na sua gestão. Desta forma, salienta-se a importância da análise dessas especificidades nos estudos dispostos a analisar a pequena empresa, servindo como fator qualitativo de avaliação.

O desempenho empresarial mede a variação quantitativa de uma variável de interesse ao longo de um período - normalmente, no âmbito dos negócios, o desempenho é medido por meio do volume de vendas anual da empresa. Na empresa, verificou-se um ganho de 
desempenho expressivo registrado entre os anos de 2002 a 2006, porém este trabalho não pôde afirmar que as mudanças realizadas e os fatores do planejamento operacional da produção, PCP, foram influentes no desempenho dela. O motivo que impossibilita essa afirmação é o fato de que outros fatores não analisados neste trabalho revelaram-se como de maior impacto sobre o desempenho, por exemplo, a ação da concorrência e a indisponibilidade de recursos de curto prazo em caixa. Estes se mostraram como fatores que desestabilizam a empresa em um período curto de tempo, enquanto as ações no âmbito do planejamento operacional são gradativas. Neste caso específico, não foi possível afirmar a relação entre PCP e desempenho, mas foi razoavelmente clara a relação entre PCP e as necessidades de crescimento da empresa, ou seja, com o crescimento da empresa e sua diversificação, aumentam as necessidades de sistematização e formalização do PCP em função da necessidade de maior controle operacional.

Uma contribuição relevante deste estudo reside no fato de que foi possível demonstrar que o desempenho de uma empresa, e principalmente as de pequeno porte, é influenciado por diversos fatores. Isso, por sua vez, impossibilita uma relação direta entre planejamento e desempenho, ou seja, não é possível isolar planejamento e desempenho desses demais fatores, tais como: a ação da concorrência, as fontes disponíveis de insumos, a disponibilidade de recursos financeiros, as particularidades do mercado consumidor entre outras.

\section{LIMITAÇÕES DA PESQUISA}

Uma das principais limitações desta pesquisa foi o fato de ter como objeto de estudo uma única empresa, o que impossibilitou a realização de comparações nas análises e generalizações das constatações.

Por outro lado, em virtude de se tratar de um estudo abrangente e aprofundado de um único caso, foi possível analisar os aspectos específicos da gestão do empreendimento, 
ajudando na sistematização e no levantamento de evidências para o estudo das características comuns entre este porte de empresas.

\section{ESTUDOS FUTUROS}

A realização de pesquisas futuras, se possível, estudos comparativos de casos, com outras empresas de pequeno porte visando identificar fatores que intervêm em seu desempenho, passando pela análise do planejamento estratégico e operacional e das características do empreendimento, podem ajudar na busca de soluções para os problemas enfrentados por tais empreendimentos, preparando-os para enfrentar o crescente nível de competitividade encontrado no ambiente empresarial, mantendo, assim, sua contribuição expressiva para o contexto socioeconômico.

Outras perspectivas de interesse a serem consideradas nestes estudos são: 1. a inclusão da análise do dirigente da pequena empresa, pois, mesmo se tratando de $\mathrm{PCP}$, na pequena empresa o dirigente influencia muito o planejamento operacional; 2. a análise do estágio do ciclo de vida atual da empresa, que possibilitaria a construção de um modelo de estruturação do planejamento operacional em função da sua evolução futura. 


\section{BIBLIOGRAFIA}

ACKOFF, R. L. (1981). Planejamento empresarial. Rio de Janeiro: LTC.

ALBUQUERQUE, A. F. (2004). Gestão estratégica das informações internas na pequena empresa: estudo comparativo de casos em empresas do setor de serviços (hoteleiro) da região de Brotas - SP. Dissertação de Mestrado. São Carlos, EESC-USP.

ALMEIDA, M. I. R. (1994). Desenvolvimento de um modelo de planejamento estratégico para grupos de pequenas empresas. Tese de Doutorado. São Paulo, FEA-USP.

ALMEIDA, M. I. R. (2001). Manual de planejamento estratégico: desenvolvimento de um plano estratégico com a utilização de planilha excel. São Paulo: Atlas.

AMER, T.; BAIN, C. E. (1990). Making small business planning easier: microcomputers facilitate the process. Journal of Accountancy; jul; 170, 1; p.53-60.

ANDRADE, J. H.; CARVALHO, K. C.; ESCRIVÃO FILHO, E. (2004). Gestão da informação na pequena empresa: identificação de tipos e fontes de informação relevantes para a administração estratégica. In: XI Simpósio de Engenharia de Produção, Bauru. Disponível em: < http://feb.unesp.br/dep/simpep/ana11.html >

BERMAN, J. A.; GORDON, D. D.; SUSSMAN, G. (1997). A study to determine the benefits small business firms derive from sophisticated planning versus less sophisticated types of planning. The Journal of Business and Economic Studies; Fall; 3, 3.

BORTOLI NETO, A. (1980). Tipologia de problemas das pequenas e médias empresas. Dissertação de Mestrado. São Paulo, FEA-USP.

BURBIDGE, J. L. (1981). Planejamento e controle da produção. São Paulo: Atlas.

CANDIDO, G. A. (2000). As formas de atuação e a necessidade do pensamento estratégico nas pequenas e médias empresas. In: VII SIMPÓSIO DE ENGENHARIA DE PRODUÇÃO, Bauru. Disponível em: < http://feb.unesp.br/dep/simpep/ana7.html >

CARVALHO, K. C. (2004). Gestão da informação sobre o ambiente externo na pequena empresa: estudo comparativo de casos sobre o processo estratégico no setor de serviços (hoteleiro) da região de Brotas - SP. Dissertação de Mestrado. São Carlos, EESC - USP.

CASTRO, R. L. (2005). Planejamento e controle da produção e estoques: um survey com fornecedores da cadeia automobilística brasileira. Dissertação de Mestrado. São Paulo, Escola Politécnica - USP.

CERTO, S. C. (2003). Administração Moderna. São Paulo: Person.

COLLIS, J.; HUSSEY, R. (2005). Pesquisa em administração: um guia prático para alunos de graduação e pós-graduação. 2a. Ed. Porto Alegre: Bookman. 
CORRÊA, H. L.; GIANESI, I. G. N. (1993). Just in time, MRP II e OPT: um enfoque estratégico. São Paulo: Atlas.

CORRÊA, H. L.; GIANESI, I. G. N.; CAON, M. (2001). Planejamento, programação e controle da produção: MRP II/ERP: conceitos, uso e implantação. 4a. Ed. São Paulo: Atlas.

COUTINHO, L.; FERRAZ, J. C. (1995) Estudo da competitividade da industria brasileira. Campinas: Papirus.

DAFT, R. L. (2005). Administração. 6a. ed. Rio de Janeiro: Thomson Editora.

DEMO, P. (2001). Saber pensar. 2a. ed. São Paulo: Cortez, Instituto Paulo Freire.

DIEESE (1998). Diagnóstico do complexo metal-mecânico brasileiro. São Paulo: DIEESE e $\mathrm{CNM} / \mathrm{CUT}$.

ESCRIVÃO FILHO, E. (1995). A natureza do trabalho do executivo: uma investigação sobre as atividades racionalizadoras do responsável pelo processo produtivo em empresas de médio porte. Tese de Doutorado. Florianópolis: UFSC.

ESCRIVÃO FILHO, E. (2006). Pequena empresa e administração estratégica: reconhecendo especificidades, restrições e facilitadores com o mapa organizacional. Tese de Livre Docência. Universidade de São Paulo.

FILION, L. J. (1999). Diferenças entre sistemas gerenciais de empreendedores e operadores de pequenos negócios. Revista de Administração de Empresas - RAE/FGV, São Paulo, v.39, n.4, p.6-20, out./dez.

FISCHMANN, A. A.; ALMEIDA, M. I. R. (1991). Planejamento estratégico na prática. 2 a. ed. São Paulo: Atlas.

GAITHER, N.; FRAZIER, G. (2005). Administração da produção e operações. 8a. ed. São Paulo: Pioneira.

GOLDE, R. A. (1986). Planejamento prático para pequenas empresas. In: Coleção Harvard de Administração. São Paulo: Nova Cultura, v. 9, p.7-34.

HALL, R. H. (2004). Organizações: estruturas, processos e resultados. São Paulo: Prentice Hall.

HILL, T. (1987). Small Business: production/operatinos mangement. London: Macmillan Education.

IBGE (2006). Pesquisa industrial mensal. Disponível em: <http://www.ibge.gov.br> (novembro/2006).

INVESTIMENTOS DO GOVERNO DO ESTADO DE SÃO PAULO. Classificação das empresas em função do setor de atuação. Disponível em: <www.investimentos.sp.gov.br/setores> 
JUNQUEIRA, G. S. (2003). Análise das possibilidades de aplicação de sistemas supervisórios no planejamento e controle de produção. Dissertação de Mestrado. São Carlos, EESC-USP.

LEONE, N. M. C. P. G. (1991). A dimensão física das pequenas e médias empresas: à procura de um critério homogeneizador. Revista de Administração - RAUSP, São Paulo: FEA/USP, v.31, n.2, p.53-59, abr./jun.

LEONE, N. M. C. P. G. (1999). As especificidades das pequenas e médias empresas. Revista de Administração - RAUSP, São Paulo: FEA/USP, v.34, n.2, p.91-94, abr./jun.

LONGENECKER, J. G.; MOORE, C. W.; PETTY, J. W. (1997). Administração de pequenas empresas: enfase na gerência empresarial. São Paulo: Makron Books.

LYLES, M. A.; BAIRD, I. S.; ORRIS, J. B.; KURATKO, D. F. (1993). Formalized planning in small business: increasing strategic choices. Journal of Small Business Management; Apr; 31, 2; p.38-50; ABI/INFORM Global.

MANETTI, J. (2001) How technology is transforming manufacturing. Production and Inventory Management Journal. First quarter 2001; 42, 1; p.54-64 ABI/INFORM Global.

MARIOTTO, F. L. (2003). Mobilizando estratégias emergentes. Revista de Administração de Empresas - RAE/FGV, São Paulo, v.43, n.2, p.78-92, abr./maio/jun.

MARTINS, R. A. (1993). Flexibilidade e integração no novo paradigma produtivo mundial: estudo de casos. Dissertação de Mestrado. São Carlos, EESC-USP.

MATTAR, F. N. (1988). Os motivos que levam as pequenas empresas à morte. Disponível em: <http://www.fauze.com.br/artigo33.htm> (jul./2006).

MENDES, J. V.; ESCRIVÃO FILHO, E. (2002). Sistemas integrados de gestão ERP em pequenas e médias empresas: um confronto entre o referencial teórico e a prática empresarial. Gestão e Produção, v.9, n.3, p.277-296, dez.

MIGliATO, A. L. T. (2004). Planejamento estratégico situacional aplicado à pequena empresa: estudo comparativo de casos em empresas do setor de serviços (hoteleiro) da região de Brotas - SP. Dissertação de Mestrado. São Carlos, EESC-USP.

MIGLIATO, A. L. T.; ESCRIVÃO FILHO, E. (2004). A pequena empresa e suas especificidades: uma proposta de classificação fundamentada em um modelo de concepção organizacional. In: VI SEMEAD. Disponível em: < http://www.ead.fea.usp.br/Semead/7semead/index.htm>

MINISTÉRIO DO TRABALHO E EMPREGO. Classificação nacional das atividades econômicas. Disponível em: 〈http://www.mte.gov.br>

MINTZBERG, H. (1994). The fall and rise of strategic planning. Harvard Business Review, jan-feb. p.107-114.

MINTZBERG, H. (1995). Criando organizações eficazes: estrutura em cinco configurações. São Paulo: Atlas. 
MINTZBERG, H. (2004). Ascensão e queda do planejamento estratégico. Porto Alegre: Bookman.

MOTTA, F. G. (2000). Fatores condicionantes na adoção de métodos de custeio em pequenas empresas: estudo multicasos em empresas do setor metal-mecânico de São Carlos/SP. Dissertação de Mestrado. São Carlos, EESC-USP.

MOURA, R. A.; BANZATO, J. M. (1994). JIT - Jeito Inteligente de trabalhar: a reengenharia dos processos fabris. São Paulo: IMAM.

NAKAMURA, M. M. (2000). Estratégia empresarial para as empresas pequenas e médias. Dissertação de Mestrado. São Carlos, EESC-USP.

PEREIRA, C. A. (1999). Ambiente, empresa, gestão e eficácia. In: CATELLI, A. (coord.) Controladoria: uma abordagem da gestão econômica - GECON. São Paulo: Atlas.

PORTAL TRIBUTÁRIOS (2006). Simples Federal. Disponível em: <http://www.portaltributario.com.br/tributos/simples.html> (outubro/2006).

PIRES, S. R. I. (2004). Gestão da cadeia de suprimentos: conceitos, estratégias, práticas e casos. São Paulo: Atlas.

PORTER, M. E. (1986). Estratégia competitiva: técnicas para a análise de indústrias e da concorrência. 7a. ed. Rio de Janeiro: Campus.

RESENDE, M. O.; SACOMANO, J. B. (2000). Princípios dos sistemas de planejamento e controle de produção. Notas de aula. São Carlos: Publicações EESC-USP.

ROBBINS, S.; COULTER, M. (1998). Administração. 5a. ed. Rio de Janeiro: Editora Prentice-Hall do Brasil Ltda.

RUE, L. W.; IBRAHIM, N. A. (1998). The relationship between planning sophistication and performance in small business. Journal of Small Business Management; Oct; 36, 4; p.2432; ABI/INFORM Global.

SANCHES, M. A. G. (2005). A influência dos estilos de gestão nas estratégias de inovação em pequenas empresas: um estudo multicasos de pequenas empresas do Pólo Tecnológico de São Carlos-SP. Dissertação de Mestrado. São Carlos, EESC - USP.

SCHERMERHORN, J. R. (1999). Administração. 5a. ed. Rio de Janeiro: LTC.

SEADE (2004). Pesquisa setorial do Estado de São Paulo. Disponível em:. $<$ http://www.seade. gov.br> (dezembro/2006).

SEBRAE (2003). Sobrevivência e mortalidade das empresas paulista de 1 a 5 anos. Relatório final. Disponível em:<http://sebraesp.com.br/novo/pesquisa/index >(abr/2004)

SEBRAE (2005). Boletim estatístico de micro e pequenas empresas. Observatório Sebrae, $1^{\circ}$ Semestre de 2005. Disponível em: <http://sebrae.com.br/pesquisas> (maio/2006) 
SEBRAE (2006). Estatuto da micro e pequena empresa. Disponível em: $<$ http://www.sebraesp.com.br/topo/fique\%20de\%20olho/informa\%C3\%A7\%C3\%B5es/le gislacao//estatuto.pdf > (outubro/2006).

SHRADER, C. B.; MULFORD, C. L.; BLACKBURN, V. L. (1989). Strategic and operational planning, uncertainty and performance in small firms. Journal of Small Business Management; Oct; 27, 4; p.45-60; ABI/INFORM Global.

SILVA, C. A. V. (2004). Redes de cooperação de micro e pequenas empresas: um estudo de atividades de logística no setor metalúrgico de Sertãozinho/SP. Dissertação de Mestrado. São Carlos, EESC-USP.

SILVA, E. L.; MENEZES, E. M. (2000). Metodologia da pesquisa e elaboração de dissertação. Florianópolis: Laboratório de Ensino a Distância da UFSC.

SINGER, P. (1985). A formação da classe operária. São Paulo: Atual Editora.

SLACK, N.; CHAMBERS, S.; HARLAND, C.; HARRISON, A.; JOHNSTON, R. (1999). Administração da produção. São Paulo: Atlas.

SOUZA, C. A. (2000). Sistemas integrados de gestão empresarial: estudos de casos de implementação de sistemas ERP. Dissertação de mestrado. São Paulo, FEA-USP.

SOUZA, C. A.; ZWICKER, R. (1999). Um modelo de ciclo de vida de sistemas ERP: aspectos relacionados à sua seleção, implementação e utilização. In: IV SEMEAD, FEAUSP, São Paulo. Disponível em: <http://www.ead.fea.usp.br/Semead/4semead/index.html>

SOUZA, M. C. A. F. (1995). Pequenas e médias empresas na reestruturação industrial. Brasília: Editora SEBRAE.

STEINER, G. A. (1979). Strategic planning. New York: Free Press.

STONER, J. A. F.; FREEMAN, R. E. (1999). Administração. Rio de Janeiro: LTC.

TAYLOR, F. W. (1970). Princípios de administração científica. 7a. ed. São Paulo: Atlas.

TEIXEIRA, H. J. (1979). Descrição e análise do trabalho de dirigentes de pequenas e médias empresas. Dissertação de Mestrado. São Paulo: FEA-USP.

TERENCE, A. C. F. (2002). Planejamento estratégico como ferramenta de competitividade na pequena empresa. Dissertação de Mestrado. São Carlos, EESC-USP.

TRIVIÑOS, A. N. S. (1987). Introdução à pesquisa em ciências sociais: a pesquisa qualitativa em educação. São Paulo: Atlas.

VOLLMANN, T. E.; BERRY, W. L.; WHYBARK, D. C. (1997). Manufacturing planning and control systems. 4a. ed. New York : Irwin/McGraw-Hill.

WELSH, J. A.; WHITE, J. F. (1981). A small business is not a little big business. Havard Business Review. July-August, 59, 4, p18-32. 
WIJEWARDENA, H.; DE ZOYSA, A.; FONSEKA, T.; PERERA, B. (2004). The impact of planning and control sophistication on performance of small and médium-sized enterprises: evidence from Sri Lanka. Journal of Small Business Management; 42, 2; p.209-217.

WOMACK, J. P.; JONES, D. T.; ROOS, D. (1992) A máquina que mudou o mundo. Rio de Janeiro: Campus.

WREN, D. A. (1994). Evolution of management thought. 4a. ed. New York: John Wiley \& Sons.

YIN,R.K (2001). Estudo de caso: planejamento e métodos. 2a. ed. Porto Alegre-RS: Bookman.

ZACCARELli, S. B. (1986). Programação e controle da produção. 7a. ed. São Paulo: Pioneira. 


\section{APÊNDICES}

APÊNDICE A - Roteiro de entrevista aplicado no gerente de vendas

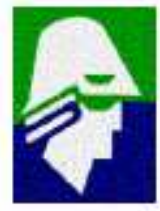

UNIVERSIDADE DE SÃO PAULO

ESCOLA DE ENGENHARIA DE SÃO CARLOS ENGENHARIA DE PRODUÇÃO

\section{Caracterização da Empresa - Gerente de Vendas}

Formação:

Tempo de experiência anterior na área de atuação da empresa:

1. A multinacional é a principal concorrente da empresa no mercado? Existem outros concorrentes relevantes? Se sim: quantos são?

2. Onde se encontra a sede da multinacional e em quais paises estão suas filiais?

3.Levando-se em conta a carteira de clientes da empresa, qual a proporção (\%) de clientes diretos/finais e revendedores/distribuidores?

4. Por quais razões os clientes compram da empresa e não da concorrência? 
5. Quanto representa o volume de negócios de exportação da empresa quando comparado ao volume total de negócios? 
APÊNDICE B - Roteiro de entrevista aplicado no proprietário-dirigente

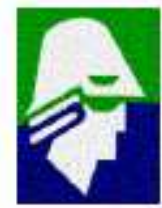

\author{
UNIVERSIDADE DE SÃO PAULO \\ ESCOLA DE ENGENHARIA DE SÃO CARLOS \\ ENGENHARIA DE PRODUÇÃO
}

\title{
Caracterização da Empresa - Dirigente
}

Formação:

1. Qual foi a principal motivação para abertura da empresa?

2. Com quantos funcionários a empresa contava no inicio de sua atividade?

3. Quais eram os produtos fabricados pela empresa no inicio de sua atividade?

4. A média do volume de vendas (faturamento bruto anual) dos dois primeiros anos de atividade da empresa representa quanto (em percentual) do volume de vendas de 2006 ?

5. Como foi o acesso aos primeiros clientes?

6. Quantos foram os primeiros clientes cativos da empresa? 
7. Qual foi o acontecimento que representou uma investida da empresa rumo a novos mercados e a conquista de novos clientes?

8. Em quais anos foram apontadas as maiores taxas de crescimento do volume de vendas da empresa? E quais foram essas taxas de crescimento?

9. Tomando como base o ano de 2002, qual foi o volume de vendas nos anos posteriores (faturamento bruto total)?

\begin{tabular}{|c|c|}
\hline Ano & Volume de vendas \\
\hline 2002 & 100 \\
\hline 2003 & \\
\hline 2004 & \\
\hline 2005 & \\
\hline 2006 & \\
\hline
\end{tabular}

10. Em sua opinião o que fez o volume de vendas variar desta forma durante os anos apontados acima? 


\section{APÊNDICE C - Diário de Campo}

\section{OBJETIVO}

Relatar as experiências e observações junto à empresa objeto de estudo, tendo como base a vivência diária como estagiário e posteriormente como funcionário na mesma.

\section{PRIMEIROS CONTATOS COM A EMPRESA E CONTRATAÇÃO}

Pouco conhecida e divulgada na cidade, principalmente por se tratar de uma empresa que atende um nicho de mercado muito específico e fabrica bens de capital, não havia um conhecimento prévio por parte do pesquisador em relação à empresa.

O preenchimento da vaga de estágio se deu devido a uma indicação de um consultor de qualidade e amigo de MBA do proprietário. Destaca-se que este amigo do proprietário é consultor na implantação de um sistema de gestão da qualidade ISO 9001:2000 na empresa objeto de estudo, iniciada em outubro de 2003. A atividade de estágio foi realizada de novembro de 2003 a outubro de 2004 e foi parte integrante do currículo do curso de Engenharia de Produção da EESC-USP. Após o termino do estágio o pesquisador foi efetivado na função de Supervisor de PCP.

Pelo fato de não possuir um programa de estágio estruturado e um programa de atividades para o estagiário, as atividades do estagiário foram assistidas e orientadas internamente na empresa pelo proprietário-dirigente da mesma, o qual ocupa a função de Diretor Industrial. Este por sua vez descreveu como sendo as principais atividades a serem realizadas pelo estagiário em um formulário fornecido pela seção de estágios da USP o seguinte: 'Planejamento e Controle de Produção, Processos de Fabricação, Controle de Estoque, Almoxarifado, Organização, Administração da Fábrica, Análise de Resultados, Liderança, Produção, Controle de Qualidade ISO 9001:2000'. A principio achei que ele tinha exagerado na descrição, mas logo percebi que ele queria tudo isto mesmo e quase tudo ao mesmo tempo.

\section{RELATO DE OBSERVAÇÕES E EXPERIÊNCIAS NA EMPRESA Agosto de 2004}

05/08/2004 - As primeiras observações na empresa foram estranhas, percebi que os departamentos trabalham bastante isolados e que o fator de integração é o proprietário, que detendo o conjunto geral de informações (incompletas e imprecisas na maioria das vezes, percebo mais tarde) e necessidades da empresa, aciona a produção de seu modo.

A sala do PCP, na qual fui 'instalado', compartilha o espaço com Projeto/Engenharia, a qual no momento é ocupada apenas pelo projetista que atua na empresa em tempo parcial. A 
funcionária do PCP esta instalada na sala de Suprimentos para não ficar sozinha na sala do PCP e por receber orientações do gerente de suprimentos para cadastrar os itens e as estruturas dos produtos no sistema informatizado em suas 'sobras' de tempo.

A empresa encontra-se em processo de implantação de um Sistema Integrado de Gestão (chamado SGI-Sistema de Gestão Industrial, de uma empresa fornecedora de Bauru), iniciada em setembro de 2003 e em processo de preparação para certificação ISO 9001:2000.

No inicio de fevereiro iniciamos o levantamento de informações para geração de ordens de produção $(\mathrm{OP})$. No primeiro momento foi preciso criar um formato para o relatório de OP que atendesse o estilo requerido pelo proprietário. Após umas cinco revisões consegui chegar no formato desejado e logo na seqüência este formato foi adaptado ao sistema integrado de gestão e começamos a gerar as ordens. Em maio de 2004 geramos as primeiras ordens de produção, de inicio implementamos apenas no setor $\mathrm{CNC}$ a fim de se fazer um teste e refinar o treinamento dos funcionários. Foi preciso muito trabalho e conversa para vencer a resistência dos funcionários em preencher 'papelzinho'.

10/08/2004 - A funcionária responsável pelo PCP da empresa desenvolve atividades relacionadas ao cadastro de materiais no novo sistema (produtos e matérias-primas), coleta diária de pedidos junto ao departamento de vendas, realização das atividades de faturamento junto ao proprietário e ao departamento financeiro (conciliando prazos de entrega, necessidades financeiras e informações pertinentes para a emissão de notas fiscais). $O$ planejamento de materiais fica por conta do gerente de suprimentos e a programação da fabrica fica por conta do encarregado de montagem, estes por sua vez recebem uma cópia do pedido de vendas (um romaneio interno sem valores) e a partir de então tomam suas providências isoladamente.

Todas as manhãs a funcionária do PCP se reúne com o encarregado de montagem para verificar o que a fabrica poderá entregar ao final do dia tendo em vista as opções de pedidos em carteira, a capacidade momentânea da fábrica e um pouco se sua vontade e disposição no dia (extremamente pessoal e informal). Os ajustes necessários são realizados pelo proprietário, o qual puxa a produção e as compras de materiais em função das necessidades de faturamento e dos prazos comprometidos com clientes (as vezes tarde e sem critérios).

13/08/2004 - Os produtos fabricados pela empresa dependem de diversos tipos de matériasprimas, entre eles constam componentes fundidos em diversas ligas de aço (WCB, CF8, CF8M e CA40) e em ferro fundido nodular (GGG 40.3), microfundidos (um processo de 
fundição especial de materiais com lead time de entrega de 40 dias em média fundição+tratamento químico), chapas e barras de aço, diversos tipos de fixadores (parafusos, porcas, prisioneiros, anéis de trava entre outros), juntas de vedações especiais, conexões, tubos e outros componentes fruto dos projetos próprios da empresa.

A empresa possui atualmente uma linha bastante variada de produtos contando com 15 famílias de produtos, as quais diversificam-se em grupos com variações no produto final em termos de bitolas, materiais, tipos de conexão e aspectos de montagem. Isto por sua vez é um fator que dificulta bastante a programação da fábrica, o planejamento de materiais e o controle de estoque, principalmente pelo fato de que a demanda dos produtos é bastante heterogênea, variável e predominantemente de baixo volume. Existem alguns períodos do ano em que há uma predominância da venda de determinada família de produto, mas nem todo ano isto se concretiza, por exemplo, a venda de um determinado produto para usinas: quando as usinas de açúcar e álcool param para manutenção pode ser trocado o produto inteiro, assim como, apenas alguns kits de reposição, ou ainda, se os técnicos de manutenção acharem que está tudo bem, nada é substituído.

18/08/2004 - Os departamentos de Vendas e Financeiro compartilham um determinado nível de integração, pois utilizam um sistema informatizado comum, no qual são registradas as transações de vendas, a emissão de notas fiscais, a geração de títulos bancários e os lançamentos financeiros referentes a contas a pagar e a receber. No entanto, os demais departamentos da empresa encontram-se em processo de implantação do sistema SGI, possuindo uma comunicação extremamente informal, segmentada e falha.

Existe um determinado nível de envolvimento familiar na empresa, a filha do proprietário é gerente de RH, o filho é auxiliar de marketing e a sobrinha é assistente de RH.

22/08/04 - Percebo a empresa como um sistema antagônico, cada departamento ou função querendo maximizar seus próprios critérios de desempenho este problema é significativamente mais intenso quando a empresa trabalha de forma desintegrada levando à perda de eficácia global (compras, marketing,financeiro, manufaturas,rh, etc...) Maximização da eficiência das partes, e olha que já me avisaram sobre isto na teoria dos sistemas!

30/08/2004 - Exemplo da falta de programação considerando o todo da empresa e os fatores externos (fornecedores): devido à "fúria" por gerar faturamento o dirigente antecipou a data 
prometida por vendas para um cliente (exportação - $1^{\mathrm{a}}$ compra), entretanto o PCP já havia iniciado e comprometido a programação de materiais e produção com a data previamente estabelecida. Nas palavras do dirigente: "Por que você foi colocar prazo para o pessoal de compras, esquece essa data, precisamos de TUDO para ontem”. Essa decisão de antecipar tal pedido comprometeria os demais pedidos do período, no entanto o reducionismo momentâneo por parte do dirigente não deixou que ele enxergasse tais implicações, além de inviabilizar a entrega de alguns itens por parte dos fornecedores externos.

O ERP possui um processo de negocio definido em sua lógica e a empresa possui uma cultura e/ou maneira própria de desenvolver suas atividades (integradas ou desintegradas), daí surgem as principais dificuldades de implantação. Ex: Sistema de entrada de material quando a Nota Fiscal (NF) é lançada na entrada, mas no caso do Terceiros - "apagadores de incêndio", que devido a sua limitada capacidade de produção e a falta de programação prévia fazem entregas parciais inviabilizando a emissão de NF $\rightarrow$ possível soluções: Flexibilizar o ERP quebrando parcialmente sua lógica!!! (tudo é uma questão de 'o sistema tem que se adaptar à gente', mesmo que estejamos fazendo errado!).

\section{Setembro de 2004}

06/09/2004 - "Ilhas de Informação a deriva na empresa": no geral as pessoas seguram as informações como forma de se proteger. Ex: a funcionária do PCP com pedidos (informação sobre itens, prazo de entrega), o encarregado da montagem com macetes na montagem de determinados produtos (ele sabe onde tem problema no projeto, mas dá um jeitinho e não conta pra ninguém), o encarregado do setor de máquinas CNC (macetes na programação das máquinas), o dirigente restringindo acesso eletrônico a desenhos entre outros e mantendo segredo no preço de venda dos produtos (isso não pode descer na produção, nem eu posso ver o preço dos produtos).

Para trabalhar no PCP, vamos ter que construir caminhos para chegar a estas 'ilhas', só na cabeça de alguns não dá, algumas informações são essenciais para busca de melhorias e propostas de solução.

08/09/2004 - ISO 9000 pode ser interpretada na empresa como ferramenta/mecanismo de Estrutura Organizacional - coordenação pela padronização! (Estrutura Organizacional e normas, ISO: coordenação a partir da padronização - Processo, Trabalho e Produto). Talvez esse seja um possível caminho para chegar às ilhas de informação à deriva, uma forma de justificar a extração da informação e do conhecimento das pessoas, documentando-as e 
tornando esta informação/conhecimento propriedade da empresa e não de pessoas isoladas. Olha a tal gestão do conhecimento!

Perfil extremamente técnico do dirigente e crença por parte do mesmo de que o caminho seja que os demais auxiliares na tomada de decisão também o sejam (técnicos). Ex: "Vai ter curso de usinagem na Sandvick, seria interessante que você fizesse"; "vem ai um sábado, vai lá e mexe nas máquinas CNC"; "não acredito que vocês não vêem isso no curso" (referindo se a métodos de fixação da peça para usinagem). Forte incentivo para realização de cursos: Estoques, Palestra de MBA, treinamento no SGI em Bauru por dois dias.

Soluções complexas para problemas simples. Caso da montagem das válvulas. "Você precisa ousar mais... que tal se fizéssemos um dispositivo giratório, acionado por mancal pneumático”. Sugestão minha: melhorar Lay-out de trabalho, fazer montagem em dupla. Acho que ele não conhece a frase que se encontra no rodapé do formulário do consultor de qualidade: 'uma solução viável implementada no próximo mês é melhor do que uma solução perfeita implementada no próximo ano'.

09/09/2004 - Criticas ao envolvimento familiar: "Esse mortinho fica ai e nem atende o telefone ao menos" (a assistente de vendas); "Quer ele ai para vocês, ele não faz nada lá mesmo" (gerente de vendas). Todos se referindo ao filho do proprietário que trabalha junto ao departamento de vendas.

A gerente do RH também é super-autoritária, manda e desmanda, dá palpite nos demais departamentos, trata os funcionários de modo descortês (será que ela faz isso só por que é filha do dono!).

"É fácil quebrar, basta dar um passo maior que a perna" - o dirigente reconhece a necessidade de cautela ao justificar o motivo pelo qual não fechou (na versão dele) um contrato com os mexicanos que visitaram a empresa por dois dias para a produção de produtos com a marca em parceria para comercialização no México.

13/09/2004 - Profissionais experientes se perdendo e desanimados com a bagunça.

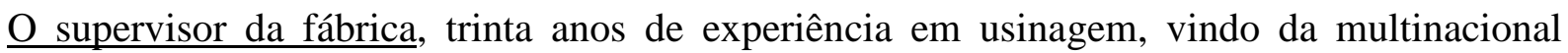
concorrente após ter se aposentado e sido dispensado em um corte de gastos, foi contratado em maio deste ano como supervisor geral da fábrica, possui muito conhecimento sobre a usinagem dos produtos fabricados pela empresa;

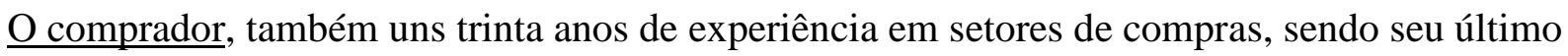
emprego na multinacional concorrente, aposentou-se e também foi cortado numa redução de 
gastos, veio para o departamento de suprimentos a fim de ajudar na organização e explorar seu conhecimento junto a diversos fornecedores da multinacional;

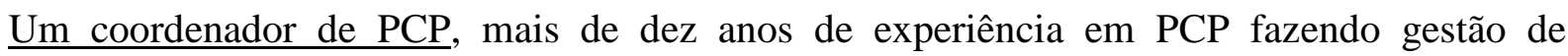
materiais em duas grandes empresas, sua penúltima passagem foi por uma empresa fabricante de cabos telefônicos em São Paulo, chegou até a empresa devido a uma empreitada do dirigente em busca de pessoas experientes como forma de resolver os problemas da empresa, ficou apenas dois meses na empresa e foi dispensado por falta de dinamismo e pelo resultado de seu trabalho não ter aparecido (acho que ele nem teve tempo, mas o dirigente achou melhor dispensá-lo antes de ele se estabelecer na cidade ou pior ainda, trazer a família e depois não dar certo).

Por algumas vezes percebi que essa bagunça dispersa pela empresa é que dá uma tremenda flexibilidade, tudo é passível de mudança instantânea (“ou não dá pra você fazer 01 peça pra mim”), tirar um funcionário de outra atividade para fresar, temperar, retificar e lapidar uma peça, depois outro para montar, perda de eficiência, mas eficaz no ponto de vista de um pedido isolado.

14/09/2004 - Influência da variedade do produto e da diversidade de clientes (demanda).

As decisões gerenciais (principalmente as relacionadas à manufatura) apóiam-se num tripé pessoas-informação-tecnologia, os quais podem ser melhor empregados a partir de uma estrutura organizacional bem definida (quem faz o que; que resultados deve gerar e para quem; quem coordena e avalia os resultados etc). Estes pilares (Informação - pessoas tecnologia) quando bem estruturados levam à eficácia organizacional (fazer a coisa certa) e quando as pessoas são devidamente treinadas e coordenadas permite a eficiência (fazer da maneira certa), conduzindo à tão sonhadora eficácia eficiente!

Uma grande quantidade e variedade de dados encontram-se dispersos pela empresa (pedidos, materiais pela fábrica, informações de alteração de peças em relação a desenho na cabeça dos operadores), isso faz com que a cada tomada de decisão seja necessário garimpar estes dados para que a decisão seja a mais embasada possível, nem sempre isso é realizado e as decisões são tomadas de forma precipitada ou exigem uma quantidade de trabalho muito grande, pois esses dados são dinâmicos. (Ex: eterna recontagem de estoque; peças que se encontram com desenhos sem revisão levando a fabricação em terceiros (principalmente) de peças erradas, como por exemplo, lotes de 1000 e 500 peças a serem retrabalhados internamente e sem ao menos a possibilidade de reclamar ao fornecedor, passamos informação incompleta). 
Devido ao estilo mais centralizador do dirigente as pessoas não assumem postura de tomada de decisão e quando o fazem tomam decisões demasiadamente cautelosas prejudicando o funcionamento organizacional (que poderia ser melhor em termos de desempenho). Ex: Departamento de compras - ora quer comprar demais para não se preocupar por um bom tempo com aquele item e neste caso prejudica a eficiência financeira da empresa comprometendo a capital de curto prazo com itens que podem ficar no estoque por muito tempo, outrora não compra pois esta sofrendo pressão para redução de gastos ou simplesmente por desorganização.

15/09/2004 - O dirigente vem até minha sala reclamar pelo fato de ter acabado um tipo de esfera. Defendo-me dizendo que nem sei do fato e ele destaca que eu deveria saber, pois eles já haviam até tirado nota do pedido que dependia desta esfera.

Nas palavras dele: "Pô assim não dá vocês não se entendem, um dança samba outro rock, vocês precisam se acertar...aqui cada um dança num ritmo e o pior é que tem uns dançando tango e outros valsa" (reconhecendo que alguns funcionários trabalham quando querem).

Fui até a sala do dirigente para conversar sobre o levantamento do estoque de algumas peças, somos interrompidos pelo gerente de vendas que traz um e-mail de mais de uma pagina sobre uma reclamação de alguém de uma distribuidora reclamando que 10 itens de um determinado produto estavam vazando na Sadia. O gerente de vendas destaca que justificou para o cliente que isso não poderia ter acontecido pois $100 \%$ dos produtos são testados no vapor e Dirigente confirma tal teste. Entretanto, ambos sabem que o teste não é realizado 100\%. Pois o inspetor de qualidade vem batendo nesta tecla a uns 5 meses mas ninguém toma nenhuma providencia, inclusive o próprio dirigente em certa ocasião não deixou fazer o teste $100 \%$ devido ao maior consumo de gás na caldeira e demora para as peças ficarem prontas. Todos se iludem e pior transferem a culpa dizendo que são os funcionários que não fazem a atividade direito.

16/09/2004 - A dias um assistente de suprimentos vem reclamando do não registro da saída e entrada de materiais nas fichas de estoque por um dos funcionários do almoxarifado. "Querem me nomear chefe/responsável do almoxarifado, mas ninguém vem aqui falar para ele me obedecer. Eu digo e ele ri da minha cara e não esta nem ai”. Nada é formalizado, tudo fica verbal e não respeitado.

O mesmo acontece por toda fábrica, as pessoas recebem autoridade fictícia, entretanto ninguém formaliza tal autoridade. Com isso prevalece o medo do proprietário e não o respeito - chama a atenção cedo e vai contar piada a tarde. 
O projetista relata o descontentamento da funcionária do PCP caso ela tenha que se reportar a mim. Nesta mesma semana ela havia dito ao dirigente que os cadastros no SGI estavam todos errados e faltando muita coisa. Entretanto, por discordar da forma que estabeleci para inserir os dados no sistema, ela seguiu caminho próprio e está lançando as estruturas de produto em uma planilha Excel, tudo para não receber ordens de alguém que chegou a pouco como estagiário (como o próprio dirigente já comentou, os ritmos não se entrosam).

Percebo que falta, por parte do dirigente, cobrar e valorizar as pessoas por resultados e não ficar ditando como fazer e questionando a forma de fazer a atividade.

O supervisor da fábrica, veio como a pessoa que colocaria 'ordem na casa' (organização e respeito aos horários de trabalho), devido aos seus trinta anos de experiência como funcionário da empresa concorrente, mas aos poucos a desorganização dominante na empresa e a falta de autoridade fizeram com que tudo virasse baderna novamente.

20/09/2004 - O proprietário solicita uma reunião com o encarregado da montagem, do CNC, com o supervisor da fábrica, com a funcionária do PCP, com o gerente de suprimentos em com o estagiário do PCP. Esta reunião foi convocada devido ao não atendimento de alguns prazos de entrega. O proprietário abre a reunião solicitando que falemos sobre onde estamos errando.

Para o encarregado do CNC o maior problema é que não falamos a mesma linguagem e por isso as pessoas tem que ficar 'reciclando a informação' que vem de diversas fontes. Para ele seria preciso fazer e colocar numa lousa na fábrica o organograma da empresa, assim, segundo ele, as pessoas sabem a quem devem se reportar e fica definido um canal único de informação (formalmente). Neste ponto o proprietário o interrompe para dizer que não faz sentido fazer um organograma pois não é objetivo da empresa definir autoridade e que isso não ajudaria na resolução dos problemas.

O gerente de suprimentos diz estar havendo uma grande indefinição nos departamentos da empresa (várias pessoas fazendo a mesma coisa e por fim ninguém assume a responsabilidade pela atividade e sua consecução). A funcionária do PCP destaca que tem encontrado diversas dificuldades para realizar seu trabalho, entre elas a falta de informação e de parâmetros para executar suas atividades.

Após esta reunião, o dirigente decide dar dois dias para que levantemos todas as pendências da produção para atender as notas fiscais emitidas referentes a programação da fábrica e faltas de materiais. Porém ao final da tarde o dirigente já cobra resultados da reunião realizada no período da manhã e acrescenta novos pedidos a serem entregues, confundindo a 
programação da produção. No final todas as pessoas que participaram da reunião deixaram as atividades de lado, pois no dia seguinte já estavam sendo cobradas de coisas que não haviam sido planejadas e que só seriam possíveis de realizar se as outras coisas comprometidas fossem paradas.

21/09/2004 - Constatação: Aqui as pessoas vivem sobrecarregadas e não possuem parâmetros e/ou autonomia para conduzir seu trabalho. Tudo muda muito rápido, um simples telefonema de um cliente reclamando ou fazendo uma consulta de pedido, pode modificar toda a programação estabelecida para a fábrica. O reducionismo (visão de um único pedido) compromete o todo sem o mínimo de análise.

23/09/2004 - O dirigente com sua pergunta tradicional ("e ai, vai ou não vai"), inicia uma conversa solicitando uma percepção minha da situação. Destaco a complexidade que temos em mãos, pois temos ganhado muitos clientes e a chance de perdê-los é enorme. Questiono-o sobre o pedido de exportação para a Argentina ("possivelmente não vamos conseguir atender no prazo previsto, devido a falta de materiais"). Com ar de desânimo, ele pergunta sobre o que irá faltar, mostro-lhe os itens que não temos em estoque, ele reflete por instantes e destaca que 'realmente vai ser difícil atendermos, pois temos 10 dias de prazo para entrega e um tempo de aquisição da matéria prima em torno de 15 dias'.

24/09/2004 - O dirigente cristaliza em sua mente que o problema são os outros e as pessoas acabam figurando como grandes culpados pelo fato da empresa não conseguir atender sua demanda e conviver com atrasos, falta de qualidade e desorganização.

Não existe um foco, tudo vira prioridade. Questiono a funcionária do PCP a respeito do faturamento ("por que ficar tirando NF se não estamos entregando? O cliente só vai pagar quando receber a mercadoria?). Na visão da administração da produção o problema é que a partir do momento que se tirou a NF, mesmo que tenhamos parte do pedido pronto não podemos entregá-lo parcialmente. Entretanto a funcionária do PCP destaca que esta é uma briga de longa data na empresa (Vendas vs. Dirigente e Financeiro). Cria-se na verdade um faturamento fictício, além de uma pressão demasiada (cobrança do cliente pelo fato de receber a duplicata antes do produto) e um problema de difícil solução na produção em vista da limitação de recursos (equipamentos - mão-de-obra - matéria-prima). \{10/08/2006 - Ao reler esta passagem corrijo-me no seguinte aspecto: tirar NF antecipada é uma maneira de manter financeiramente a empresa, os pedidos a prazo são mais interessantes no dia-a-dia para 
empresa do que os pedidos a vista, pois as duplicatas geradas são descontadas em bancos e compõem o capital de giro do empreendimento. O faturamento não é fictício!!!! \}.

27/09/2004 - Mais uma bobeada na compra de peças em terceiros: fez-se uma compra de 500 peças de determinado item, tais peças são cortadas no lazer e foram compradas às pressas devido a quebra de estoque e a pressão do dirigente sobre o departamento de suprimentos. Devido à correria foi enviado para o fornecedor um desenho errado (sem furos - desenho muito antigo de estampagem), como não houve uma comunicação eficiente e um procedimento de verificação para envio (envolvendo suprimentos - projeto - controle de qualidade). Suprimentos solicitou para projeto o desenho para cotação, projeto imprimiu o desenho errado, C.Q. carimbou e assinou o desenho (sem questionar a finalidade do desenho) e como resultado recebemos 500 peças, trazidas por um moto-boy na metade do prazo do fornecedor e que não podiam ser utilizadas, pois os furos são essenciais para o processo de dobra da peça e exigem precisão - apenas obtida no processo lazer. Ninguém assumiu ou reconheceu o erro, as peças foram reprovadas pelo C.Q. no recebimento e continuamos sem peça. A solução mais cabível foi dar um jeitinho e furar as peças manualmente uma a uma para possibilitar a entrega dos produtos que dependiam de tal peça. Esta situação demonstrou a necessidade criar mecanismos que possibilitassem refinar a comunicação entre os membros da empresa e um pouco mais de formalidade na troca de informações, evitando erros tão simples, mesmo passando por diversas pessoas na empresa.

\section{Outubro de 2004}

13/10/2004 - Consultores de qualidade e do sistema informatizado reclamando da falta de autonomia para executar seu trabalho na empresa e a cobrança do dirigente ao definir 'como fazer' (ex.: formato de relatório, tela do sistema), ao invés de cobrar resultados ele diz como as pessoas devem fazer seu trabalho.

Consultor do sistema informatizado espantado: 'Como vocês fabricam se não tem uma ordem de produção ou algo parecido'. Pena que ele não sabe que a coisa vai mais longe, até os desenhos muitas vezes são deixados de lado (alguns operadores dizem que sabem as medidas de cabeça), passamos por uma tremenda dificuldade para tirar este hábito deles e motivar profissionalização das atividades.

18/10/2004 - Alta rotatividade de funcionários, nesta data aponto que já foram embora desde quando entrei aqui: Elen (auxiliar de compras - 6 meses), Messias (comprador - 2 anos), 
Jesus (torneiro mecânico - 6 anos), Piere (operador de furadeiras - 4 anos), Reinaldo (operador CNC - 5 meses), Raimundo (controle de materiais/PCP - 2 meses), Éderson (vendedor - 3 meses), José Carlos (operador CNC - 7 meses), Marcos (ferramentaria - 6 meses), Dagoberto (qualidade - 8 meses). Entraram na empresa neste período também: Fabiane (auxiliar de compras), Lincon (auxiliar de compras/modelos de fundição), Senne (torneiro), Mario (fresador), 2 aprendizes de CNC, Fabio (montagem), Vlademir (inspetor de qualidade), Candido (almoxarifado), Luiz (comprador), Sr. Nelson (processista e auxiliar temporário no PCP), Sr. Hélio (supervisor).

Em relação à rotatividade, tudo é uma questão de se adaptar à bagunça e gerar resultados (para manter-se por competência) ou ter afinidade com o proprietário para se manter na empresa nos períodos de vendas escassas.

19/10/2004 - Em 16/10 foi realizada pelo consultor de qualidade uma palestra sobre ISO 9000, os funcionários, apesar de questionarem bastante, mostraram-se bastante receptivos, principalmente ao saber que alguém (possivelmente o dirigente) teria que assinar 'um papel' se responsabilizando pelo fato de se fabricar algo que estivesse não conforme. Exemplo: peças com dureza elevada, de um lote de 70pç das quais, nove tiveram problemas em uma única operação no CNC, o dirigente quando viu queria saber por que o encarregado do CNC não interrompeu a produção e por quê o C.Q. não inspecionou as peças quando chegaram. "Quem vai pagar isso agora, você, você....". Entretanto em nenhum lugar na empresa havia algum registro que especificasse a dureza recomendada para as peças e essa informação, segundo compras, foi passada verbalmente ao fornecedor (este por sua vez fabrica de acordo com o seu processo sem atentar a este fato), desta forma não há como cobrar o fornecedor e na empresa as variações de dureza são verificadas e discutidas verbalmente, sendo que a conclusão de que não dá para usinar se dá na prática, na máquina (impossibilidade de usinar, desgaste excessivo de ferramentas etc) e quando o nível de cobrança para que a peça fique pronta já é auto.

21/10/2004 - O dirigente é bastante cuidadoso para não definir uma atividade muito bem para as pessoas, pois assim ele mantém a flexibilidade de delegar e cobrar tarefas variadas das pessoas. "Organize seu tempo e faça isso mais isso e mais isso....".

25 e 26/10/2004 - O dirigente reconhece a necessidade de exercer liderança e não só a autoridade por ser dono. "Preciso me afastar um pouco da produção, mas para isso é 
necessário comprometimento dos responsáveis". (até então ele tem em mente que só com sua presença a coisa funciona e na verdade as pessoas se acostumaram com esta idéia).

\section{Novembro de 2004}

08/11/2004 - A funcionária do PCP esta quase em enlouquecendo por ter que gerar requisição manual de materiais para saída de peças do almoxarifado (de acordo com as necessidades diárias de produção - pelo fato do cadastro das estruturas de produto não estarem terminadas). Entretanto antes de fazer ela se preocupa sobre onde vão surgir as dificuldades ("a fábrica vai parar, não vai dar tempo, os pedidos de vendas tem que chegar em horários pré-definidos para ter tempo de analisa-los etc etc").

10/11/2004 - O dirigente faz outra reunião para 'pedir' que no PCP agilizemos o cadastro no SGI, desta vez um prazo de duas semanas foi estabelecido.

O dirigente faz comentários sobre os encarregados (montagem e $\mathrm{CNC}$ ), segundo ele, eles são as maiores resistências aos processos de mudança na empresa e os maiores conhecedores dos produtos e processo da empresa: "Pensa que é fácil mudar, as pessoas não tem respostas quando são questionadas, elas têm perguntas!”; para contornar as dificuldades ele sugere a contratação de funcionários jovens para aprender e substituir os funcionários velhos de casa e extremamente arredios à mudança.

16/11/2004 - O dirigente reconhece em uma conversa a necessidade de mudança na cultura da organização. Demonstra um grande interesse em contratar uma consultoria externa para o diagnóstico de problemas (que ele não aceita quando pessoas da empresa relatam). Nesta ocasião apresento uma proposta de esboçarmos um processo de negócio com metas claras para que então possamos delegar e cobrar resultados das pessoas, assim como comprometimento e responsabilidade. Ele destaca a necessidade de trabalharmos na cultura do pessoal, buscando comprometimento dos mesmos.

22/11/2004 - Observo que as pessoas sempre recorrem a situações negativas do passado para justificar por que não estão fazendo as coisas como sabem ou deveriam estar fazendo ou alternativamente elas tem dificuldade de assumir autoridade quando lhes é dada (inspetor de qualidade, por exemplo, autorizado a parar as máquinas quando surgissem problemas e não deixar que se faça algo errado, sem desenho e etc, sempre questionado sobre a falta de relatórios sobre defeitos/refugos/retrabalhos), porém tem medo de agir e não ter respaldo. 
Nesta mesma data questiono um operador sobre alguns apontamentos manuscritos nos cartões de mão de obra, ele destaca que "o serviço esta apertado, ainda mais agora que o Marcos (outro operador do setor) foi embora, trabalhar em outra empresa ganhando quase cinco por hora". Ficou nítido nesta ocasião o desconforto de alguns funcionários por trabalharem na empresa, trabalhando bastante e não tendo o mesmo reconhecimento principalmente financeiro que outras empresas oferecem. O nível de desmotivação é tão alto que fica difícil cobrar dos funcionários maior empenho, em certos momentos chega a não fazer sentido cobrar mais empenho deles.

30/11/2004 - A funcionária do PCP pede demissão por não agüentar mais o nível de cobrança imposto (principalmente da forma que são feitas, pelo departamento de vendas em conjunto com o proprietário) e pelo fato de não enxergar soluções para os problemas que a empresa enfrenta. Em relação às atividade de PCP ela deixa claro que é impossível de se trabalhar ("ele quer tudo ao mesmo tempo").

\section{Dezembro de 2004}

01/12/2004 - A discussões com o dirigente são freqüentes, pois ele quer que tudo seja realizado da maneira que ele pensa, qualquer decisão tomada que contrarie sua opinião é motivo para discussão, mesmo que os resultados sejam bons. Falta espaço para que as pessoas possam utilizar seu conhecimento e tomar postura de tomada de decisão, predomina o medo de contrariar e ser a próxima vítima dos gritos do dia.

07/12/2004 - O dirigente me questiona “E ai está mais confiante lá embaixo?”. Respondo que sim, "parece que vamos conseguir organizar. Ele responde: "Ah com esse pessoal que temos ai, vai ser difícil, vamos colocando este pessoal novo e ver no que dá”.

Com a saída da funcionária do PCP suas atividades são acumuladas em mim, porém junto ao dirigente peço ajuda para realizar ao menos as atividades de faturamento. Neste momento ele aproveita para me questionar sobre quando ficarei em tempo integral na empresa - questão da efetivação.

08/12/2004 - Caso do rapaz do almoxarifado de ferramentas, seu ultimo emprego foi uma empresa grande da cidade, não agüentou a desorganização e a falta de recursos para trabalhar e abandonou no segundo dia de emprego. Era um funcionário extremamente sistemático nas suas atividades, já no primeiro dia, organizou o almoxarifado de ferramentas e criou uma lista 
de retirada de ferramentas para controle. Porém, para motiva-lo ainda mais a sair, recebeu um chamado para ir trabalhar na Techunsen.

13/12/2004 - O fluxo de informação para o PCP melhora bastante. Mesmo trabalhando por três tenho conseguido planejar a compra de materiais e casar as necessidades de vendas/faturamento com a produção no chão de fábrica mesmo tendo algumas limitações. Agora começo a sistematizar o fluxo de informações, porém algumas dificuldades ainda existem, como por exemplo, o supervisor de produção não aceitando a programação derivada do PCP.

16/12/2004 - O dirigente me informa sobre a contratação de um gerente de produção com experiência para que ele possa se afastar da fábrica. Este por sua vez é um ex-funcionário da multinacional que vai começar na empresa em janeiro de 2005. Nesta ocasião fica definido que minha função para 2005 seria de supervisor de PCP, reportando-me a este novo gerente.

\section{Janeiro de 2005}

03/01/2005 - Chegada do gerente industrial (que pediu a conta na empresa que trabalhava para vir para cá), ele configura-se como mais um para compor o ciclo de profissionalização da gestão na empresa. Pelas primeiras conversas observo que ele possui bastante experiência e uma visão abrangente sobre o setor de atuação, produtos e processos da empresa.

24/01/2005 - Em poucos dias já começam algumas reações negativas por parte de algumas lideranças sobre a atuação do novo gerente. Sua interferência no departamento de suprimentos ao reclamar da qualidade, dos prazos e outros aspectos é vista negativamente pelo gerente de suprimentos; suas incursões na produção são problemáticas devido à resistência do supervisor da produção e os desmandos do proprietário. Não ficou claro para alguns que a solução de problemas que antes passavam pelo proprietário agora devem ser direcionadas ao gerente.

\section{Fevereiro de 2005}

10/02/2005 - O novo gerente realiza um trabalho muito bom junto com o consultor de qualidade, fazendo toda a formalização do processo produtivo via documentação de procedimentos, projeto dos produtos, adequações nas máquinas (vibra stop, identificação entre outras). 
Sua experiência é aproveitada também no projeto de novos produtos e para realizar adequações nos produtos já existentes.

Já estamos gerando ordem de produção para todos os itens fabricados na empresa e os funcionários já estão se acostumando a preencher as ordens. Já realizei dois treinamentos com eles e busquei demonstrar a importância deste documento para o PCP e para o sistema de gestão definido para a empresa.

16/02/2005 - É fácil perceber a ansiedade e angústia do dirigente ao ter que abrir mão de parte do controle operacional da fábrica e se segurar para não mudar as coisas realizadas pelo gerente. Porém, o nível de autonomia do novo dirigente ainda é bastante limitado, algumas ações ainda dependem do aval do proprietário.

\section{Março de 2005}

03/03/2005 - Dificuldades no mercado de atuação levam fabricantes e revendedores a uma situação de calamidade. Surge a necessidade de realizar demissões para se adequar ao volume de vendas atual. É delegado ao gerente o papel de comunicar a demissão aos funcionários demitidos, nesta ocasião foram demitidos sete funcionários da produção e três da área administrativa.

Temos um conjunto de NF atrasadas e parece não ter solução para colocarmos os prazos de entrega em dia. Ocorrem muitas falhas de comunicação devido a ânsia de vender a qualquer custo e prazo, como exemplo houve o caso das 9 válvulas de grande porte - cliente tinha detalhes técnicos que não atendíamos, mas mesmo assim foi realizada a venda resultado:todas as peças foram devolvidas para adequação, que só seria possível com a fabricação de um componente fundido novo sob medida, um custo extra de aproximadamente R\$ 10 mil.

07/03/2005 - O encarregado da montagem entra de férias e então surge a necessidade/oportunidade do PCP assumir maior controle sobre a programação do serviço na montagem. Evolução da lista gerada manualmente pelo encarregado para a programação diária de produção gerada no PCP (planilha excel), com isso tentamos fugir do vicio de montar apenas os pedidos do dia e começar a gerar algum estoque de produtos acabados. 


\begin{abstract}
Abril de 2005
05/04/2005 - As necessidades de faturamento persistem. Não há um planejamento financeiro, apenas trabalhamos de acordo com as necessidade de fluxo de caixa. Faturamos coisas complicadas (falta matéria prima, capacidade fabril etc). Diversas NF atrasam, temos que prorrogar títulos no banco ("como vou ficar explicando para o gerente do banco" diz a assistente do financeiro). O proprietário inibe/restringe a terceirização ("tem que fazer aqui, é fácil”), porém a fábrica esta no limite, mesmo fazendo horas extras.

O clima de stress dissemina-se até os funcionários operacionais (o operador de fresa pediu a conta, o almoxarife discutiu com os montadores sobre atrasos nas peças para expedição e até chorou, caos total). O novo gerente não tem autonomia para atuar e decidir, eu então fico cada vez mais limitado e sem respostas no PCP.
\end{abstract}

\title{
Maio de 2005
}

06/05/2007 - As vendas reagem, porém a reação não é persistente, o mercado reage com os investimentos em ampliação ou construção de novas plantas de algumas empresas. Para motivar as revendas a comprar é preciso realizar algumas promoções com descontos de preços e maiores prazos de pagamento.

17/05/2007 - Os trabalhos para a certificação ISO 9000 estão a toda velocidade, pelo menos duas vezes por semana temos ficado até $23 \mathrm{~h}$ na empresa (eu, o consultor, o gerente e um inspetor de qualidade). A maior preocupação é chegar na pré-auditoria com tudo em ordem. Uma grande dificuldade tem sido fazer com que aquilo que desenvolvemos pós-horário de trabalho seja assimilado nos processos de trabalho dos dias seguintes (organização e padronização dos procedimentos operacionais).

\section{Junho de 2005}

07/06/2005 - O clima entre o dirigente e o gerente não está muito bom, o gerente tem muita vontade de fazer e inovar, porém a empresa não consegue absorver financeira e estruturalmente, faltam recursos e respaldo. Suas modificações no projeto do produto são muito boas, reduzindo custos e melhorando o desempenho do produto, porém o dirigente questiona e coloca empecilhos dizendo que as mudanças vão causar problemas futuros, porém ele não aponta as causas para estes problemas futuros. Com isso o gerente fica bastante desmotivado por suas ações não serem reconhecidas, ocorrendo também algumas discussões com o dirigente. 
27/06/2005 - Após alguns contatos com um órgão certificador da ISO, fechamos um pacote para o processo de certificação. Foi agendada para o dia 8 de agosto a Pré-auditoria de certificação. Agora não tem mais para onde fugir.

30/06/2005 - Hoje o gerente foi demitido. Sem dar maiores detalhes, por volta das 10:00h, o dirigente chamou o gerente em sua sala e o comunicou de sua demissão, justificando que a empresa passa por momentos difíceis e por isso não daria para mantê-lo no quadro de funcionários.

\section{Julho de 2005}

06/07/2005 - Após a saída do gerente o dirigente fez uma reunião com o supervisor da produção/fábrica, com o inspetor de qualidade, com o supervisor de PCP e com o gerente de suprimentos. Nesta reunião ele pediu empenho de todos e para que nos ajudássemos para darmos continuidade nas principais atividades iniciadas pelo gerente (essencialmente a certificação ISO e as melhorias na fábrica), ele pediu para que eu (supervisor de PCP) coordenasse os trabalhos e ficasse como a figura responsável pela área 'industrial'. Ele, por sua vez, dedicaria a maior parte de seu tempo para cuidar das questões de projeto do produto e buscaria interferir o mínimo possível nos assuntos da fábrica. Vamos ver se ele agüenta!

13/07/2005 - Os trabalhos para confecção de documentos e procedimentos para a fábrica já estavam difíceis de serem realizados com a ajuda do gerente, agora a carga de trabalho ficou maior ainda. Temos que nos desdobrar para dar conta do dia-a-dia e das atividades de preparação para certificação. Buscamos envolver mais pessoas, mas não é fácil, não há interesse em se envolver, as pessoas não se comprometem com o trabalho e querem fazer de qualquer jeito. O jeito é vir aos sábados também para dar conta.

Vivemos um outro dilema, o encarregado da montagem e do CNC não colaboram e ainda fazem campanha contra a certificação ISO dizendo aos outros funcionários que "esse pessoal ta preocupado só com papelzinho". Antes eles faziam isto as escondidas, mas agora procuram nos intimidar dizendo que não vão colaborar e que se depender deles o certificado não sai. Tentamos contornar explicando a importância do certificado para empresa poder ganhar mercado e se organizar internamente, porém eles sempre arranjam um questionamento novo, ora querem saber se vai ter uma contra-partida salarial, novos benefícios, máquinas novas e etc. 
27/07/2005 - A alguns dias atrás o encarregado da montagem questionou o proprietário sobre o processo de certificação ISO 9000 da empresa, na ocasião ele deixou claro que não iria colaborar e que ainda iria dificultar o máximo possível, neste dia ele estava irritado por conta da forte cobrança do proprietário para que fossem entregues determinados pedidos. Naquele dia o proprietário não discutiu muito, porém já deve ter começado a se preparar. Hoje perto do fim da jornada de trabalho a gerente de RH chamou o encarregado na sala de reunião e o demitiu.

\section{Agosto de 2005}

08/08/2005 - Hoje passamos pelo processo de pré-auditoria. Após uma baita correria para deixar a 'casa' em ordem envolvendo a limpeza da fábrica, arrumação e até pintura de algumas paredes, recebemos o auditor e obtivemos um resultado bastante positivo. Nossa documentação foi bastante elogiada por ser bastante clara, bem estruturada e objetiva (mérito do consultor e seus modelos de documento), tivemos apenas duas sugestões de melhoria relacionada ao atendimento de reclamações de clientes e no contato com os fornecedores para a solução de problemas. Agora é só esperar a auditoria de certificação em setembro, porém nesta será dois auditores, nossa sorte na amostragem de inspeção vai ter que ser maior!

11/08/2005 - Com a saída do encarregado da montagem suas atribuições de comandar e orientar a realização do serviço ficaram por conta do supervisor da fábrica (sugestão do proprietário). Porém tenho que interferir diversas vezes para ajudá-lo a coordenar o trabalho da montagem, estamos sobrecarregados.

\section{Setembro de 2005}

13/09/2005 - Chega a tão esperada auditoria de certificação ISO 9000. Tivemos um dia bastante desgastante, pois os auditores (2) ficaram na empresa o dia todo. O auditor líder foi o mesmo da pré-auditoria, o auditor assistente ficou conhecendo a empresa nesta oportunidade e questionou tudo, desde os procedimentos operacionais que documentamos até a maneira de armazenar barras de aço e as condições de trabalho na sala de teste dos produtos. O saldo desta auditoria foi uma não-conformidade e duas sugestões de melhoria, mas felizmente obtivemos o certificado. 
16/09/2005 - Foi realizada uma festa para todos os funcionários da empresa em comemoração ao sucesso do processo de certificação. Agora precisamos colocar o pé no chão e manter as rotinas.

O departamento de Vendas e Marketing não perde tempo e já lança uma campanha de divulgação do certificado da empresa, a idéia agora é atingir clientes que exigem o certificado como fator qualificador para o fornecimento de materiais (como por exemplo Petrobrás e outras grandes empresas, além de proporcionar maiores chances de penetração no mercado externo).

\section{Novembro de 2005}

22/11/2005 - Definição e nomeação de lideres, a fim de distribuir responsabilidades, assim como autoridade para melhorar o desempenho da produção. Ismael - líder do setor de montagem (5 subordinados) - escolhido devido ao maior conhecimento sobre a linha de produtos e facilidade de relacionamento com os demais funcionários da montagem. Odair (2 subordinados) - líder do setor de caldeiraria, rebarbação e pintura - escolhido pelo fato de ser o mais experiente do setor e já estar ensinando os demais funcionários do setor a algum tempo. Gleisson - líder do setor de usinagem CNC - escolhido pelo fato de ser o mais experiente em programação das máquinas, devido ao seu conhecimento em relação às peças e devido à sua dedicação em ajudar nos momentos em que a empresa precisou. Na verdade esses funcionários já tinham postura de liderança, pois eram aqueles que mais se envolviam na solução de problemas. A partir de então esses funcionários foram chamados a fazer parte da programação da fábrica, em função da lista diária de prioridades geradas pelo PCP, os mesmos ficam responsáveis por acompanhar a execução do trabalho, assim como apontar as necessidades de materiais, equipamentos ou as dificuldades em atender os prazos desejados devido algumas anomalias em processo (ajudariam no controle de produção). Em primeira instância eles foram orientados a recorrer ao Sr. Hélio (Supervisor da Fábrica), principalmente quando dependessem das peças da usinagem convencional e ao José Henrique (Supervisor do PCP), quando se tratasse de problemas relacionados à falta de materiais ou problemas com as ordens de produção. Buscou-se na verdade criar um clima dinâmico de cobrança a fim de resolver os problemas assim que os mesmos ocorrem da forma mais rápida possível, evitandose o não atendimento de prazos ou ociosidade nos setores.

De início houve muita resistência para a aceitação dos lideres, pois os demais funcionários relutavam em os aceitar como lideres, com o Supervisor da Fabrica também não foi diferente, pois ele estava acostumado a "mandar em tudo", dando ordens a todos funcionários 
diretamente e a partir de então foi preciso discipliná-lo a respeitar a linha de comando definida (passando pelos lideres, para que esses passem as ordens a seus subordinados). No entanto, foram necessárias algumas reuniões para esclarecer o papel, a autoridade e responsabilidades do lideres perante os demais funcionários.

\section{Dezembro de 2005}

Desde a definição dos lideres e dos conflitos e desmotivações geradas anteriormente pelas incursões do Proprietário na produção (Projetista que pediu demissão, Supervisor de Produção que queria pedir também etc), a tendência foi um distanciamento do mesmo em relação à programação da fábrica e ao trato direto com os funcionários, este por sua vez começou a respeitar mais a linha de autoridade definida, limitando-se a apenas cobrar de forma mais coerente as necessidades de entrega e a resolução dos problemas do dia-a-dia. Com isto ele teve mais tempo para se dedicar à gestão mais estratégica do negócio (análises de mercado, visita a clientes chave, análise do projeto dos produtos, análises financeiras do empreendimento, participação de cursos e seminários, busca de novas fontes de financiamento para o empreendimento - entre elas a participação de um congresso de investidores promovido pelo ministério de ciência e tecnologia, no qual foi cogitada a possibilidade de um fundo de investimento aplicar recursos na empresa).

\section{Janeiro de 2006}

Assim como em 2005 o volume de vendas começa baixo e as dificuldades de caixa se mostram mais intensas, entretanto existe a crença de que após o carnaval a economia vai engrenar. Como conseqüência as compras passam a ser limitadas à aquilo que esta sendo vendido, para estoque apenas aqueles itens que possuem alto giro e possuem algumas limitações de fornecimento (exemplo: microfundidos - tempo de obtenção 45 dias), por sua vez fica cada vez mais difícil atender aos prazos curtos que o departamento de vendas tem que oferecer para ganhar pedidos no mercado. Do mesmo modo a competição também fica mais acirrada no que diz respeito a preços (pouca demanda e bastante oferta) e um concorrente multinacional de grande porte com bastante 'fôlego' para concorrer em preço.

Cresce o envolvimento familiar na empresa, mais um filho e uma nora começam a trabalhar no departamento de compras.

\section{Fevereiro de 2006}


Saída do supervisor de vendas, um engenheiro mecânico vindo de uma experiência em duas grandes empresas, ele recebeu proposta de uma multinacional japonesa do ramo de automação industrial para gerenciar um novo escritório de vendas em Campinas com uma equipe de vendedores composta por 11 engenheiros, segundo ele com salário dobrado em relação ao que a empresa o oferece hoje, mais um conjunto de benefícios atraentes, uma estrutura fabril composta por uma nova planta em Diadema com 94 máquinas operatrizes trazidas dos Estados Unidos. Isto por sua vez demonstra a fragilidade da pequena empresa em manter funcionários bastante qualificados.

\title{
Março de 2006
}

14/03/2006 - Inicio da emissão de notas fiscais pelo novo sistema informatizado. Foi preciso tomar uma decisão radical, pois se fossemos aguardar os sistema estar pronto para tal não iríamos começar a 'virar' o sistema. Em paralelo continua a luta para fazer o sistema funcionar para controle de estoque. Desde quando iniciei na empresa já foram pelo menos umas cinco contagens de estoque a fim de iniciar o controle, mas sempre esbarramos em algum problema (ora não tinhas gente para manter atualizadas as baixas e entradas no estoque, outrora esbarrávamos em problemas operacionais - muita gente dado palpite e impondo como fazer e neste momento estamos em uma grande indefinição de como alinhar nossas necessidades e realidade à estrutura do novo sistema.

\begin{abstract}
Abril de 2006
14/04/2006 - O líder da montagem pela segunda vez se manifesta para solicitar aumento de salário em função da promoção para líder do setor. Segundo ele, em uma conversa informal com o também promovido a líder do setor CNC, descobriu que o mesmo já havia sido registrado com a nova função na carteira, com aumento de salário e ajuda de 50\% para cursar faculdade. Isto por sua vez deixou-o frustrado e o motivou a chegar a mim e pedir aumento, já que o proprietário disse a ele que qualquer funcionário que quisesse aumento deveria se dirigir a seu líder imediato, este por sua vez me informaria e só depois de uma avaliação minha e dele é que o pedido deveria chegar a ele (dirigente). Isto ressaltou um aspecto interessante, mesmo os funcionários tendo sido promovidos em novembro/dezembro de 2005, apenas um havia recebido a promoção de fato (formalmente), os demais ficaram apenas com as responsabilidades da função. No entanto após conversarmos foi acordado que os outros dois funcionários que haviam sido promovidos a lideres teriam seus benefícios corrigidos a partir de maio.
\end{abstract}


20/04/2006 - Preparação para auditoria ISO9000: conflitos com o consultor, poucos se engajam nas atividades e a desculpa geral é a sempre a mesma "por conta das atividades do dia-a-dia não consigo manter minhas rotinas em ordem e fazer o levantamento de dados necessários". No entanto a auditoria já havia sido adiada em um mês e mesmo assim poucos se mexeram. Outros até justificavam que ninguém avisou que tinha atividades a serem realizadas, porém os manuais da qualidade, assim como os procedimentos dos responsáveis por sinal continuavam intocados.

O consultor, eu e o inspetor de qualidade montamos um esquema de trabalho intenso para conseguir fazer pelo menos o mínimo necessário para a auditoria. As jornadas de trabalho se estendem até $23 \mathrm{~h}$, sábados, domingos e já estamos até empenhados de trabalhar no 21 de abril e $1^{\mathrm{o}}$ de maio (feriados). Tudo isto, pois vivemos o dia-a-dia apagando incêndios e deixando a os procedimentos sempre para depois "afinal de contas a auditoria é só em abril, depois fazemos.......ah a auditoria é só em maio, vamos ver isto daqui pois temos que entregar este pedido hoje...", somado ao fato de que temos poucos recursos humanos para dar conta do trabalho.

29/04/2006 - Estamos trabalhando em um sábado pela manhã e Cláudio chega apresentando para mim e para o consultor (Marcos) sua idéia de montar um portal para estabelecer uma parceria com fabricantes complementares de produtos relacionados à geração de energia via vapor. Segundo ele, sua busca é de uma alternativa enfrentar a sazonalidade do mercado em que atuamos, os próximos passos são estruturar a idéia e apresentar para nossos principais clientes (revendas) afim de verificar a viabilidade da idéia.

\section{Maio / Junho de 2006}

O clima de descontentamento na empresa é geral, o mercado contínua bastante difícil e não há uma reação sustentada da economia, como as vendas são fracas, o estoque por sua vez baixou bastante para determinados itens (não podíamos comprar, pois não estávamos vendendo). Por volta de $80 \%$ dos pedidos que entram possuem prazos extremamente curtos que para serem atendidos dependem de um grande esforço no departamento de suprimentos junto aos fornecedores (principalmente fundições) e na produção demanda um grande uso de horas extras, principalmente nas máquinas gargalo (tornos convencionais - torneiros entrando as $6 \mathrm{~h}$ da manhã e ficando até $18,19 \mathrm{~h})$. As contratações também estavam suspensas devido às incertezas da economia. 
A pressão excessiva principalmente por parte do Proprietário ("tudo para ontem", falta de prioridades, o 'sufoco' financeiro, etc), sobrecarrega os funcionários do nível administrativo levando muitos a brigarem entre si e conversarem com o proprietário a respeito da vontade de abandonar a empresa, este por sua vez através do diálogo consegue segura-los na empresa.

05/05/2006 - Reunião dos representantes da cada setor da empresa para 'afinar' o diálogo para a auditoria. O representante da administração sugere para que todos busquem justificar as falhas m seus respectivos departamentos em função da falta de recursos ocasionada por um segundo semestre de 2005 difícil e por conta da implantação do novo sistema informatizado. No entanto o não cumprimento das atividades deve-se a falta de foco e em muitos casos de dedicação dos mesmos por falta de comprometimento ou sobrecarga de trabalho.

08/05/2006 - primeira auditoria de manutenção da certificação ISO 9000. Apenas uma não conformidade por conta de um fornecedor não aprovado (referente a uma não conformidade anterior), que ainda constava na lista de fornecedores aprovados do departamento de suprimentos e um ponto de melhoria por falta de informações no pedido de compras enviado a fornecedores (número de desenho e revisão atual do mesmo no pedido de compras).

15/05/2006 - Por conta da grande sobrecarga vivida durante o período em que fiquei sozinho no PCP e devido ao acúmulo de procedimentos ISO9000 sob minha responsabilidade, solicitei ao proprietário um período para dedicação exclusiva ao mestrado, mesmo tendo relutado bastante ele aceitou e comecei a trabalhar em regime de horário especial, a fim de dar continuidade à programação das atividades da fábrica e manter as rotinas do PCP. Com meu novo ajudante já treinado a cerca de 45 dias isto se tornou possível. Entretanto, certas atividades continuavam muito dependentes de mim. Isto retrata a dependência da pequena empresa em relação a algumas pessoas-chave, detentoras de muitas informações que convivem junto destas pessoas não pelo simples fato que segurarem a informação/conhecimento mas principalmente por não ter a quem transmiti-lo.

18/05/2006 - Cláudio comenta novamente sobre o plano de motivação e incentivo para os funcionários. Ele se mostra bastante engajado e preocupado em criar na empresa um clima de 'melhoria'. No dia anterior Juliana já havia falado a respeito da aplicação do questionário nos funcionários buscando captar as expectativas deles em relação à empresa, os supervisores, as aspirações dos funcionários etc. 
15/05 a 15/06/2006 - período no qual trabalho em horário diferenciado para me dedicar mais às atividades de mestrado. $\mathrm{O}$ analista de $\mathrm{PCP}$, contratado a três meses, fica tomando conta das atividades de PCP nos momentos que não estou na empresa. Neste período trabalho a quartafeira de cada semana em horário normal e nos demais dias a partir das $17 \mathrm{~h}$ para programar o dia seguinte da fábrica. Quando estou ausente é difícil manter a programação, pois proprietário interfere e modifica o programado durante alguns dias. Percebo como a informação não flui quando não estou na empresa, um fica deixando para o outro e no fim ninguém toma as ações necessárias, em todos os setores da empresa é uma inércia danada (1. compras não faz follow-up dos pedidos, assim os materiais atrasam e só ficamos sabendo no momento da necessidade do material, pois também o Evandro ainda não tem o timing de liberação das ordens de produção e não estou para 'pentelhar' os caras de compras lembrando dos materiais que não chegaram; 2. Vendas não faz uma análise crítica dos pedidos e assim coisas absurdas são vendidas - exemplo válvula redutora com flanges adaptadas exigindo um face-a-face que é $2 \mathrm{~mm}$ maior do que o da válvula normal roscada - isto por sua vez resultou na necessidade de fabricarmos um corpo em aço carbono (o original seria em ferro fundido) e também em fazer com que o montador ficasse até meia-noite montando a válvula para sair no mesmo dia, assim como, segurar um furador, um torneiro, um soldador e um almoxarife até $22 \mathrm{~h} / 22: 30 \mathrm{~h}$. Por sua vez o custo desta válvula deve ter sido altíssimo e foi absorvido por conta da falta de sistemática e disciplina no ato da venda (faltou rigor no departamento de vendas para realizar uma análise crítica do pedido).

07, 08 e 09/06/2006 - por conta de um pedido grande que entregamos em 05/06 conseguimos um fôlego no capital de giro e não necessitamos tirar nota fiscal (NF) durante 3 dias, com isso foi possível traçar uma programação que permitiu a saída de 57 notas só nos dias 07, 08 e 09 de junho e por volta do dia 12 já não teríamos nenhuma $\mathrm{NF}$, apenas aquelas que fossem tiradas com antecipação nesta data, tudo foi uma combinação de programação adequada e disponibilidade de materiais para fabricação (objetivos realistas, claros e disponíveis para todos envolvidos). Nestes dias tive que mudar meu comportamento junto aos demais funcionários da empresa, já que tenho sido cobrado como gerente de produção, mesmo ainda não tendo sido nomeado oficialmente para a função, começo a cobrar de cada um as respostas sobre aquilo que foi deixado sob sua responsabilidade (isto por sua vez resultou em discussão com um vendedor, um almoxarife e com o analista de PCP), infelizmente as pessoas tem dificuldade em entender prioridades, respeito à hierarquia e suas rotinas de trabalho que não 
podem ser deixadas de lado mesmo que outras coisas urgentes surjam e se escondem atrás da informalidade das coisas para justificarem-se pelo fato de que "ninguém disse que precisa fazer isso ou aquilo", "fulano mandou fazer aquilo e por isso interrompi o que você havia pedido para fazer" ou "não sei o que fazer primeiro". No entanto para gerenciar as atividades dos subordinados tive que começar a me organizar um pouco melhor, colar papeis pela parede de minha sala com cronogramas especificando atividades, responsáveis e prazos para também não entrar na ciranda da informalidade e me esquecer daquilo que prometi fazer ou daquilo que passei para que outros façam, até mesmo comecei a cobrar mais do proprietário os recursos básicos para a realização do trabalho (ex. ligação as $19 \mathrm{~h}$ de sexta-feira para cobrar impressora que estava quebrada e eu não tinha como passar o serviço para os funcionários que iriam trabalhar no CNC durante a noite - ele insiste em manter só uma localizada no piso superior, obrigando os departamentos que trabalham no piso inferior (suprimentos/compras, qualidade, PCP e Projetos) a subirem escadas a cada necessidade de impressão ou cópia de um documento - características ou resistências do pequeno empresário prejudicando a empresa (quanto tempo as pessoas perdem só de transito?).

\section{Análise sobre formalização, planejamento e certificação ISO 9001}

Algum nível de formalização é necessário quando um conjunto de pessoas constituem uma empresa, pois caso contrário fica muito difícil planejar e controlar a realização de atividades os incêndios podem fazer com que atividades ou ações importantes sejam esquecidas e só lembradas quando se tornarem um outro incêndio.

Mesmo que seja de maneira não sistemática e informal algum nível de planejamento é realizado na pequena empresa, no entanto devido a urgência de atuar em função do dia-a-dia este planejamento concentra-se naquilo que é essencial para o funcionamento da empresa. Pensar o futuro fica um pouco distante da realidade da empresa, no geral o proprietário quando pensa no futuro os acontecimentos imediatos o sufocam fazendo com que o mesmo volte às atividades direcionadas para o curto prazo. Os três dias de ótimo desempenho na produção são reflexos da soma de planejamento antecipado das atividades, execução do trabalho programado, controle e atuação dos lideres para que o planejado fosse realizado e por sua vez demonstram alguns aspectos que influenciam o desempenho.

O processo para certificação ISO obrigou a sistematização e formalização de alguns aspectos do negócio e isso por sua vez possibilitou melhorias significativas nos processos de controle, identificação de materiais na fábrica e almoxarifado, assim como, possibilitou uma forma mais clara de transmissão da informação a quem necessitasse da mesma (registros, 
documentos etc). Além de ser um evento que tornou mais urgente a necessidade de organização da fábrica (antes deixada de lado por conta do fato de "nosso negócio é fabricar peças, organizamos depois").

\section{Julho de 2006}

Por conta das cobranças do Proprietário tive que agilizar ainda mais a contratação de alguém para fazer o apontamento de produção e formalizar o plano de incentivo que ele almeja. Segundo ele, com o plano de incentivo teremos como meta: redução (todas em torno de $30 \%$ de imediato) das horas extras, redução de refugo e retrabalho, melhoria do moral dos funcionários, maior senso de união e organização entre os funcionários dos setores (metas do grupo). A idéia é ótima, porém comento com ele que para não quebrarmos a cara é preciso resolver outros fatores que estão além disso: qualidade da matéria-prima (isso sim tem dado muito retrabalho e refugo - fundidos), melhorar condições de uso das máquinas (dispositivos, manutenção preventiva rigorosa), melhor equacionamento dos prazos de entrega (pressão excessiva sem necessidade - "o que de fato é prioridade", para não quebrar tanto as programações de produção).

03/07/2006 - O analista de PCP continua errando demais (ordens de produção erradas, compra de material desnecessário e pressão desnecessária no departamento de suprimentos), isto somado aos erros cometidos durante o período no qual eu estava fora complica a situação e a todo momento o proprietário sugere que eu o mande embora. Para ele tudo se resume a uma questão de simplesmente trocar pessoas. Procuro contornar a situação e segura-lo um pouco mais pois sei do tempo investido para treina-lo e do volume de trabalho do PCP, além da dificuldade de repor outra pessoa.

06/07/2006 - Não deu para segurar mais, foi preciso dar férias ao supervisor da fábrica, com isso tive que assumir a supervisão da fábrica durante os vinte e cinco dias nos quais ele estará fora, pois não havia outra pessoa para assumir, uma opção seria promover um torneiro ou que o proprietário o cobrisse para não me sobrecarregar, porem as opções foram descartadas devido às dificuldades relacionadas (no primeiro caso devido a possíveis conflitos entre os funcionários e a alguma situação desconfortável gerada na volta do supervisor; na segunda opção não faria muito sentido pois, lutamos tanto para distanciá-lo do operacional da fábrica e agora iríamos envolvê-lo tanto no). Resumindo, estou mais uma vez sobrecarregado, tendo 
que planejar e colocar o pessoal para fazer e pior, deixando minhas atribuições centrais em segundo plano.

07/07/2006 - Melhoramos a lista de produção diária passada para os lideres da fábrica, depois das diversas versões desde aquela feita à mão pelo antigo encarregado da montagem, chegamos a uma versão mais clara, passando todas as informações necessárias para os envolvidos e com isso melhorando a comunicação do PCP com a montagem, o almoxarifado/expedição, setor de acabamento e com a usinagem, várias sugestões foram feitas pelo analista de PCP.

A lista passa a ser o objetivo diário e todos relacionados à produção estão alinhados a um mesmo objetivo, torna-se quase um pacto, programo o que é possível de se fazer, havendo uma troca de informação rápida e precisa das alterações, isto sem dúvida melhora o desempenho da fábrica pois os esforços e recursos são canalizados nas prioridades ("acordo formal", não dá pra dizer que não foi avisado ou que esqueceu, agora tudo está na lista!).

10/07/2006 - Depois de um longo período buscando um funcionário para a vaga de apontador e 6 entrevistas com candidatos, contratei um garoto de 20 anos, com curso do Senai e que estava trabalhando num supermercado. Ficou acordado dele começar em 11 de julho.

13 de julho - O proprietário desce na produção e reclama do novo torneiro contratado, pois solicitei que o horário dele fosse alterado de 12 às $21: 48 \mathrm{~h}$ para 7 às $17 \mathrm{~h}$, conversando com o torneiro e vendo as dificuldades do mesmo vi que não seria possível deixa-lo neste horário pois ele ficou 13 anos trabalhando em outras atividade e seria um risco deixa-lo sozinho na fábrica a noite. Para o proprietário "esta tudo errado, pois devemos contratar pessoas prontas, se não servir temos que trocar". Aproveito a deixa para dizer a ele que então será preciso trocar uns $70 \%$ da empresa, pois estamos lotados de incompetentes (indireta em relação aos parentes e amigos).

14/07/2006 - Em relação à colocação de Stoner e Freeman (p.13 texto de qualificação), haja capacidade de re-planejamento para agüentar as mudanças de programação da pequena empresa! Sofremos para atender os prazos das exportações, no geral os pedidos são grandes e quase paramos as outras atividades do mercado interno para atender as exportações, quando temos montagem de estações (estrutura de distribuição e controle de fluidos completa) também é uma loucura. 
Com relação às reprogramações, por exemplo, temos que criar mecanismos para apontamentos parciais nos campos da ordem de produção, devido à necessidade de interromper os lotes de fabricação e continuá-los posteriormente afim de adiantarmos apenas a quantidade necessária para o dia.

21/07/2006 - Sobre a leitura da pág. 53 de Migliato (2004), não é que os dirigentes de pequena empresa estão pouco preocupados com as necessidades de longo prazo, é que as necessidades de curto impactam na existência da empresa no futuro próximo (amanhã, na próxima semana...), portanto é preciso sobreviver hoje (curtíssimo e curto prazo) para só então pensar no amanhã (longo prazo).

31/07/2006 - Além da pequena força de vendas da empresa (ocasionando pouca penetração no mercado - maior parcela de venda para revendas e poucas vendas diretas para clientes finais), a venda do produto é extremamente técnica e demandaria um grande conhecimento da aplicação do produto em campo (conhecimento de domínio apenas do gerente de vendas). Isto por sua vez, resulta em constantes erros de especificação/análise dos requisitos préestabelecidos pelo cliente, acarretando em diversas reclamações para substituição de produtos pós-venda, gerando na produção uma pressão, que poderia ser evitada, para repor peças que o cliente já recebeu sem as características necessárias e não esta disposto a aguardar. A análise critica dos pedidos de venda não são realizadas, com isso problemas só são descobertos quando as peças vão ser programadas para fabricação, muitas vezes alguns dias depois do pedido ter sido colocado pelo cliente e por sua vez, já aceitamos e pedido, possivelmente sem ter capacidade ou condições de atender, gerando custos para customizar de acordo com as necessidades do cliente.

\section{Agosto de 2006}

01/08/2006 - As fundições começam a se negar a atender os prazos curtos que necessitamos, pois quando as peças são fundidas 'aceleradamente' há uma grande possibilidade das peças darem problemas (vazamento, irregularidades dimensionais e superficiais), e consequentemente devolvemos as peças. Além disso, começam a questionar nosso baixo volume e excessiva cobrança por prazos mais curtos. Também solicitamos em momentos de 'vacas magras' a prorrogação de títulos, ou seja, só incomodamos.

Este período do ano esta bastante difícil, quase não há tempo entre a entrada dos pedidos e a emissão das notas fiscais. 
Novamente é preciso demitir, quando o mercado reagiu alguns funcionários foram contratados, mas não deu para sustentar. Nesta ocasião até o analista de PCP foi demitido, vejo minha sistemática de planejamento e controle desestruturada novamente e fico mais uma vez sozinho para dar conta do trabalho no PCP.

\section{Setembro de 2006}

05/09/2006 - Recebemos a visita de um consultor, sugerido pelo consultor que já realiza trabalhos no departamento financeiro. A idéia é extrair da experiência dele algumas sugestões e ações que sejam úteis para a nossa situação, principalmente para o controle de estoque. Fica sobre minha atribuição mostrar a ele a fábrica e seu funcionamento, assim como, as ferramentas e recursos que utilizamos para fazer a administração da produção. Ele fez algumas sugestões de formatos para relatórios gerenciais, mas logo percebeu que temos recursos financeiros escassos e que isto é um fator a ser considerado na administração da produção e dos estoques. O principal relatório que ele sugere tem o objetivo de mostrar a carteira de pedidos segmentando-a em itens faturados e itens não faturados, o que por sua vez possibilitaria a definição de ações nos itens mais críticos de entrega (faturados). Este relatório deverá ser customizado no nosso sistema informatizado. Ao final de sua visita ele ficou de enviar um relatório de sugestões diretamente ao proprietário.

11/09/2006 - Parece que a onda de problemas não vai ter mais fim, nos últimos dias estamos gerando títulos para todos os pedidos disponíveis em carteira e pior, sem tempo para checar a disponibilidades de materiais (o principal gargalo para compor o prazo de entrega) e ainda a compras de materiais estão restritas devido ao baixo volume de vendas e desta forma não conseguimos programar lotes de compra para estoque dos itens de alta demanda. A alta variedade de produtos é um problema, pois o número de itens é alto.

\section{Outubro de 2006}

03/10/2006 - O volume de notas paradas volta a crescer e começamos a nos atropelar novamente. Faltam materiais, as ordens de produção ficam perdidas pela fábrica e o preenchimento é incompleto, uma sobrecarga enorme de trabalho no PCP. Esta cada vez mais difícil dar uma diretriz para a fábrica, tudo se torna urgente e as análises são pobres, é mais importante agir e depois parar para pensar.

As coisas voltam a ficar informais, peças saem do almoxarifado sem ordem de produção, as necessidades de compra de materiais em alguns casos são passadas verbalmente e a compra é 
realizada sem pedido (principalmente no caso de estações e produtos especiais - muitas vezes passadas pelo projeto diretamente para o comprador a fim de ganhar tempo; faltam materiais no momento da montagem, pois nos casos em que as coisas são realizadas na correria e verbalmente não se realiza a checagem via lista de materiais).

5 e 6/10/2006 - O Proprietário volta a interferir fortemente na produção, muda a programação, passa serviços aleatoriamente, muda o foco a todo instante (isto devido a nossa perda de capacidade de entrega). Brigas com o supervisor da produção, com o comprador e com o supervisor do PCP devido a prazos não cumpridos - stress total!

10 de outubro - Desde 2005 foram lançadas mais quatro famílias de produtos, parece pouco, mas representa cerca de 120 novos itens a serem controlados, fabricados e comprados (15 itens em média na estrutura dos novos produtos com variações de dimensão e material). Creio que estamos seguindo no caminho contrário da redução de custos e simplificação do negócio. Porém essa variedade é o que disponibiliza oportunidades para entrarmos em novos mercados.

25/10/2006 - Em conversa com o gerente de suprimentos falamos a respeito da situação que a empresa enfrenta no momento (baixas vendas, muitos clientes reclamando dos prazos não cumpridos, intensas cobranças e prazos extremamente curtos). $\mathrm{Na}$ opinião dele o que complica é a variedade de produtos, isto resulta em altos estoques, pois vendemos e fabricamos em baixos volumes com altíssima variedade, sendo que para alguns itens não é possível comprar apenas a necessidade devido ao tamanho dos lotes dos fornecedores. Questiono sobre como evoluiu o volume de compras nos últimos três anos: ele afirma não ter nada documentando, mas da experiência ele destaca que a empresa saiu de volume de compras de 70 a 90 mil para em média 150 mil por mês.

\section{Novembro de 2006}

01/11/2006 - Temos auditoria ISO marcada para o dia 16 deste mês. No último final de semana o inspetor de qualidade que é um dos responsáveis pela organização da documentação sofreu uma cirurgia de emergência e foi afastado do trabalho. Terei que me desdobrar para dar conta do trabalho e chegar na auditoria com o máximo possível em ordem.

Já a algum tempo venho pleiteando a contratação de alguém para me ajudar no PCP, pois a carga de trabalho esta muito intensa e tenho ficado na empresa de 10 a 12 horas e mesmo 
assim está difícil de manter a organização. Soma-se também o fato de que estou sem como tirar férias e me ausentar da empresa, pois se não o PCP pára.

13/11/2006 - Até que enfim foi disponibilizada a contratação de um auxiliar para o PCP. A análise do volume de horas extras que tenho feito 'sensibilizou' o dirigente em conjunto com o RH a disponibilizar a recursos para a vaga! Mandaremos o mais rápido possível o perfil desejado para o balcão de empregos e também anúncios para as universidades da cidade para contratar um estagiário também.

16/11/2006 - Mais uma auditoria. Sempre a mesma história, sempre nas vésperas a coisa aperta: limpa a fábrica, ajeita a documentação e seja o que Deus e o Auditor quiserem!

Mais uma vez passamos ilesos, apenas uma não conformidade devido a lista de fornecedores aprovados desatualizada da no departamento de suprimentos.

21/11/2006 - Começam a chegar candidatos para as vagas de auxiliar de PCP e estagiário. De início é luta para contratar, pois encontramos dificuldades relacionadas a pessoas com perfil para a vaga de auxiliar, três entrevistas realizadas no mesmo dia e outros três currículos avaliados como 'nada haver' com a função, sofremos com uma enxurrada de candidatos do balcão de empregos sem ao menos idéia do que é PCP. Quanto ao estagiário, recebemos quatro currículos ( 2 alunos da USP, 1 aluno da Ufscar indicado pela filha do proprietário e um aluno da Unicep).

29/11/2006 - Após as entrevistas com os estagiários selecionei um dos alunos da USP. Quanto ao auxiliar de PCP, já estou pensando em desistir, há a possibilidade de aproveitar um garoto que trabalha aqui no setor de montagem (já conhece a empresa e os produtos e é bastante dinâmico).

Felizmente as vendas reagiram bem neste mês e temos diversar cotações para os meses de dezembro e janeiro (período de parada das usinas para manutenção, as revendas não querem ficar sem peças), com isso são abertas novas contratações para repor os setores deficientes da fábrica (torneiros para as máquinas convencionais, mecânicos de usinagem para a montagem e a criação de um segundo turno no setor $\mathrm{CNC}$ ).

\section{Dezembro de 2006}


07/12/2006 - O volume de vendas está anormal (alto demais para o período), sufoco produtivo enorme e aumento da terceirização de serviços de usinagem.

São realizadas diversas priorizações para que poucas notas fiscais virem o ano, mas sem deixar de atender as metas de faturamento, várias reuniões são realizadas para estabelecer as principais metas e montar um cronograma de entregas.

Alguns clientes estão reclamando devido aos prazos não cumpridos em outras ocasiões. O não cumprimento de prazos que tentamos estabelecer junto aos fornecedores, principalmente fundições, afeta bastante nossas condições de entrega.

Fazemos alguns ajustes na fábrica para dar conta da carga de trabalho, levantamos as máquinas gargalos e temporariamente montamos um segundo turno para mantê-las disponíveis por mais horas.

11/12/2006 - Estou exausto e é hora de tirar umas merecidas férias. Eu já tinha consciência disto a algum tempo, mas a empresa só se conscientizou quando venceu a segunda e a legislação obriga. Mas antes de sair tenho que montar um esquema para manter o mínimo organizado no PCP. A opção é treinar o estagiário para gerar as ordens de produção e a lista diária de produção com o auxílio do supervisor de produção e um dos auxiliares de compra a fazer as solicitações de compra.

\section{Janeiro de 2007}

2 a 19/01/2007 -. Deixo um esquema montado para não perder a sistematização no PCP e tiro esses dias de férias, a coordenação vai ficar por conta do proprietário.

22/01/2007 - Volto e tudo esta muito confuso, abandonaram a lista diária de produção, peças estão sendo fabricadas e montadas sem ordens de produção, alguns vícios voltaram, como por exemplo, não preencher ordens, pular etapas de inspeção nos produtos e peças sendo retiradas do almoxarifado sem registros entre outras.

A fabricação das peças de exportação encontram-se paradas, não foi possível conciliar com os itens de mercado interno, faltou estabelecer um foco e cumpri-lo mesmo que outras urgências aparecessem.

Começamos o ano com excesso de problemas com dureza elevada nas peças microfundidas e problemas de precipitação no carbono quando recozidas, a gravação de números de lotes errados nas peças e, além disso, o fornecedor esta se negando a aceitar devoluções.

Saída do Mauricio do C.Q. 
Foram realizadas mais contratações, um novo funcionário na montagem, um no almoxarifado e a efetivação de um pequeno aprendiz do Senai que já trabalhava na empresa a um ano. Tivemos também uma baixa, um dos inspetores de qualidade nos deixou em virtude de ter encontrado uma proposta de trabalho melhor na sua cidade de origem.

Outro problema! Um dos compradores sofreu um infarto ontem (domingo dia 21) e o gerente de suprimentos já está com cirurgia marcada para do dia 29, ou seja, de repente ficamos com um baita problema na mão: vai ser preciso contratar e treinar um comprador em uma semana. O gerente já havia adiado sua cirurgia por duas vezes, devido à carga de trabalho na primeira e posteriormente devido ao meio período de férias, agora não vai dar mais para adiar.

29/01/07 - O gerente de suprimentos se afasta para realizar a cirurgia. Na quarta-feira da semana passada foi possível contratar um comprador, um rapaz jovem, formado em administração de empresas e com experiência em outra empresa do ramo metalúrgico no setor de compras. Em três dias foi preciso explorar o máximo da experiência do gerente de suprimentos sobre os processos de compras da empresa. A principio a gerente de $\mathrm{RH}$ e filha do proprietário irá ficar junto dele no departamento de suprimentos para ajudá-lo.

\section{Fevereiro 2007}

08/02/2007 - Já em suas primeiras atividades o novo comprador se mostra muito organizado, gera listas de pendências de materiais para facilitar o follow-up, já de início percebemos a influência da rede social que o gerente de suprimentos tinha junto a alguns fornecedores e também são revelados alguns problemas referentes à falta de sistematização das informações que estavam na cabeça do gerente, por exemplo, houve muita dificuldade para encontrar modelos de fundição, os quais estavam com os registros de localização desatualizados e sem plaquetas de identificação (exigindo o conhecimento das peças para poder reconhecê-los.

\section{Março 2007}

01/03/07 - Vinda da assistente de vendas responsável pela emissão de notas fiscais e contato com clientes a respeito de prazos de entrega para uma sala próxima da produção e aumento do seu contato com o processo de fabricação e as dificuldades para atender os prazos dados por vendas. Todo o stress de mudança de salas, ela inconformada com o calor nas salas da produção, com a falta de uma impressora, além das reclamações de praxe dela. 
Auditoria ISO 9000 em 16 de março, sobrecarga total principalmente sobre mim e do inspetor de qualidade (que inclusive será promovido a supervisor de qualidade), os demais apenas fazem aquilo que apontamos, caso contrário, ficam na boa.

Pelo visto mais uma auditoria e não vou conseguir fazer o treinamento com o pessoal da produção, fiz uma apresentação sábado em casa, mas a verba para locar um Datashow não foi liberada pelo $\mathrm{RH}$, vou tentar imprimir em transparências, e reprogramar a data do treinamento.

02/03/07 - Já no segundo dia a assistente de vendas percebe que a nossa forma de produção é uma loucura, os prazos são muito curtos e os fornecedores não tem condições ou não aceitam os prazos que impomos, fica desesperada e começa a confrontar seu próprio departamento de vendas, que até então estava certo na sua ótica e os incompetentes eram os da "produção".

05/03/07 - Estamos sem horizonte, quase tudo esta atrasado em termos de prazos de entrega para clientes, enfrentamos um período de volume de vendas elevado. Uma associação de prazos curtos, peças difíceis e demoradas, prazos não cumpridos por fornecedores (exemplo atraso nas telas perfuradas, fundidos em aço carbono e inox, fornecedores de estampados, fundição em ferro fundido com atrasos crônicos, entre outros), além da falta crônica de capital de giro nos obrigando a emitir NF todo dia em altos volumes, para pagar as dívidas contraídas para compra de materiais nos meses anteriores, também de altos volumes.

06/03/07 - Nas semanas anteriores o dirigente já havia pedido para "parar" com a terceirização pois a metas do departamento de suprimentos (volume de compras) já estavam estouradas (novidade!!! A meta não é compatível, se não comprar não fabricamos, a diversidade é tão grande que não tem como deixar de comprar, sempre tem algo acabando). Vivemos uma situação de Vendas considerando uma produção para estoque e Suprimentos/PCP uma produção sobre encomenda ou Just-in-Time, só pode comprar mediante uma efetivação de vendas. Seguramos o que foi possível, até um terceiro ficou sem serviço durante 10 dias (detalhe, ele trabalha exclusivamente para nós - foi preciso muito jogo de cintura para mantê-lo cativo), porém logo no dia 02/03 não teve jeito, a conclusão é óbvia: se não terceirizarmos não conseguimos atender os prazos impostos, fazer internamente com a estrutura que temos também não é solução. Alternativa, negociar a condição de pagamento com os terceiros para as datas mais convenientes para a empresa, como os fornecedores menores dá, já os maiores do que a gente só aceitam cobrando juros. 
Finalmente consigo transferir o garoto da montagem para o PCP e arranjo um auxiliar. O estagiário já não está tão interessado, já se nega a gerar ordens de produção, calcular os índices de refugo e retrabalho, questiona todas as atividades que lhe são passadas e gasta seu tempo navegando pela internet, creio que ele não vai ficar muito.

07/03/07 - O dirigente reclama da fábrica de modo geral "a coisa não anda", peço a ele para dar dados que demonstrem isso, ele apenas remete à quantidade de notas fiscais paradas, porem a causa disso não é o baixo desempenho da produção e sim a necessidade de levantar recursos para a manutenção do fluxo de caixa. Continuamos a discutir e peço a ele para dar sugestões para melhorar o desempenho da fábrica, ele insiste que a solução esta em encher a fábrica de material, pois assim os funcionários caminharão sozinhos rumo aos trabalhos seguintes. Até parece que quem deve ditar o foco e o ritmo de trabalho são os funcionários! Depois de toda a discussão ele conclui que precisamos racionalizar a linha de produtos, pois com a capacidade que temos a variedade é muita, não tem solução.

13/03/07 - Com a vinda do garoto da montagem, rearranjo o esquema de trabalho com ele e com o estagiário (que agora se encarregara do fechamento e arquivamento de ordens e do levantamento de tempos de produção na fábrica), o auxiliar de PCP será treinado para tocar do dia-a-dia (lista diária de produção, ordens de produção, solicitação de compras e acompanhamento/controle da produção diária, o fato dele já conhecer as peças ajuda muito), assim terei mais tempo para programar os trabalhos na fábrica e a compra de materiais.

15/03/07 - O gerente de vendas mais uma vez propõe o seu tão sonhado estoque regulador (uma quantidade a ser produzida e colocada em estoque para atender alguns pedido a pronta entrega). Colocar a quantidade no papel é fácil, difícil é viabilizar a execução, sem afetar a entrega do que ele mesmo se compromete com o cliente, peças que demoram 10 ou 15 dias para serem entregues em 3. Ele relata para ao inspetor de qualidade que tudo é uma questão de capacidade produtiva, segundo ele, no mercado em que atuamos, quem faz primeiro (nós ou o concorrente) ganha o pedido do cliente (acho que ele escolheu o campo de batalha errado para competir com a multinacional!).

16/03/07 - Auditoria ISO 9000. O resultado da auditoria foi um sucesso, apenas uma gafe na reunião de fechamento, o dirigente chega atrasado e principia uma discussão com o gerente de vendas na frente do auditor, os demais participantes ficaram extremamente sem jeito, pois 
depois de tanta classe para mostrar um processo de gestão refinado, um desfecho deste é fogo! Foi preciso muita classe pra fugir da saia justa e voltar o foco da reunião para o fechamento da auditoria.

20/03/07 - Uma grande discussão entre eu, o dirigente e o gerente de vendas. Devido à transferência da assistente de vendas para mais próximo da produção, o contato entre fábrica e vendas ficou mais estreito e até mesmo ela percebe que atender os prazos estabelecidos por vendas compromete os outros já assumidos e agora eles sabem em detalhes por que o prazo de determinado pedido não foi atendido. O gerente de vendas vai indignado ao dirigente dizer que a "produção ta ruim, pois nada sai no prazo", o dirigente leva-o até a fábrica e ao almoxarifado para mostrar que as providências estão sendo tomadas e que o prazo de entrega não tem sido compatível com a nossa realidade. $O$ gerente diz que isto não é solução para o problema maior (na verdade mais uma vez ele acordou para a questão de que não está certo ficarmos faturando antecipadamente), segundo ele precisamos de um sistema de informação que realmente funcione. Como eu estava no almoxarifado quando eles entraram discutindo, participei da conversa, segundo o gerente de vendas o problema é que ninguém registra nada. Lembro-o dos caso em que ele mesmo vai até o almoxarifado e leva materiais para clientes sem fazer a documentação necessária (autorização de expedição e baixa da pendência no sistema), e também das situações em que ele ou o dirigente pegam material e levam diretamente para a fábrica. Segundo ele isso é acontece pouco! Pergunto sobre a disciplina? E segundo eles 'os meninos' do almoxarifado devem registrar isso que eles fazem, questiono se os 'meninos do almoxarifado' tem autoridade para barrar os gerente de vendas ou o proprietário da empresa (silêncio geral). Enfim, mais uma discussão e nada resolvido, ta cada vez mais difícil entrar na deles e ficar contornando o problema ao invés de buscar soluções apropriadas.

Neste mesmo dia, ao final da tarde, o dirigente mesmo tendo ido embora liga no meu celular para propor um problema para o meu mestrado: "pense em uma empresa que por questões de fluxo de caixa, antecipa seu faturamento pagando juros junto a bancos, por uma questão de falta de capacidade produtiva ...... que tal se investirmos em capacidade produtiva e nos anteciparmos colocando material em estoque ... será que este custo de investimento em capacidade não será pago pela possibilidade de termos o produto a pronta entrega e pelo não pagamento de mais juros junto aos bancos? Pense nisto e amanhã discutimos".

Hoje o comprador que havia sofrido um infarto voltou ao trabalho e o gerente de suprimentos já vem na empresa em tempo parcial. 
21/03/07 - O dirigente chega cobrando que alguns 'incêndios' sejam apagados. Digo a ele que se atrasarmos um dia naquele caso específico que ele estava cobrando, consigo garantir a saída daquele material no dia seguinte e ainda colocar peças em estoque devido a programação da produção que fiz na noite anterior, mostro ainda a quantidade de notas que estamos mandando embora naquele dia ... a discussão vai longe, mas no final ele acaba deixando que eu mantenha a programação. Levo ele até o estoque e mostro o que consegui colocar no estoque nos últimos dias, ele se surpreende e diz que devo deixar isto mais a mostra, até rearranjar o almoxarifado para que isto fique evidente, para que o gerente de vendas veja os resultados.

29/03/07 - Aplico o questionário de caracterização no gerente de vendas. O do dirigente vou aplicar nos próximos dias, melhor deixar para uma semana mais calma.

\section{ABRIL 2007}

09/04/07 - Após alguns dias de muita discussão e interferências do proprietário na programação da produção não agüento mais e peço demissão comunicando diretamente ao proprietário. Por outras vezes já pensei em sair, mas eu sempre pensava na possibilidade de buscar soluções a partir da busca de melhorias no PCP, chego a conclusão que de nada vai adiantar tais esforços se no fundo as causas das dificuldades são outras (falta de recursos de curto prazo e respaldo do proprietário para caminhar para uma gestão mais pautada em análises e sistemático uso de ferramentas gerenciais que aprendi no curso de engenharia de produção). Dessa forma é melhor buscar novas experiências profissionais.

Tivemos uma conversa de mais de duas horas, exponho meu ponto de vista e motivos da saída. Ele apesar de querer que eu fique e até propor novos benefícios, deixa ao meu critério a decisão final. Com já estou decido confirmo o pedido de demissão. Proponho-me a ficar na empresa por mais trinta dias e treinar o auxiliar para me repor nas atividades do PCP e disponibilizar todos os mecanismos necessário para fazer uma transição sem prejuízos para o funcionamento da empresa.

12/04/07 - Hoje um torneiro mecânico pediu demissão, pois foi chamado pela empresa na qual trabalhava anteriormente para ganhar mais, segundo ele $50 \%$ mais que o salário atual na empresa. Apesar de estarmos em um momento de necessidade produtiva elevada (muitas peças a serem fabricadas) e este funcionário ter sido transferido para o turno da noite para que 
uma máquina gargalo operasse por um período maior, não deu para segurá-lo pois a diferença é muita. Desse jeito não dá para controlar a rotatividade de funcionários (turn over)!

Apliquei hoje o questionário de caracterização no proprietário, falar sobre os valores de faturamento é quase um tabu, tive que contornar bastante pra retirar algumas informações e conseguir o acesso ao departamento financeiro e extrair algumas informações com a assistente do financeiro. Volto depois para baixar a poeira.

17/04/07 - Contratação do Sr. Saulo (consultor na área de gestão da produção) para fazer um diagnóstico e me substituir futuramente na gestão industrial e no PCP. A principio ele irá passar pelos departamentos e conhecer as empresa, posteriormente ficará direto comigo para conhecer detalhes da função e atividades.

20/04/07 - Após fazermos um fluxograma do processo desde a venda até a entrega do produto, envolvendo as análises do PCP referentes aos pedidos de vendas, as necessidades de materiais e o acionamento da produção, o Sr. Saulo expõe o seguinte ponto de vista: "Isto aqui é uma mina de oportunidades, apesar de em alguns momentos ser vista por muitos como uma mina de problemas".

26/04/07 - Visita do Prof. Edmundo à empresa, conversa com o dirigente (verificando seu forte perfil empreendedor e conhecimento da área de atuação) e visita à empresa conhecendo as instalações e pessoas chaves. Conversamos sobre as possibilidades de temas para discussão: gestão do conhecimento, a partir da 'extração e disponibilização do conhecimento de e para funcionários; a questão da permanência da dependência das pessoas mesmo com a empresa tendo avançado alguns passos rumo a sistematização.

27/04/07 - Último dia de trabalho em tempo integral na empresa, porém já ficou acertado de continuar um trabalho de suporte à parte com visitas à empresa aos sábados e auxílio a distância (e-mail e telefone) para esclarecer as dúvidas e realizar possíveis treinamentos com funcionários.

Hoje consegui conversar com a assistente do financeiro, por sinal ela já estava preparada com alguns dados dos últimos cinco anos para me mostrar, porém havia uma restrição em se divulgar valores reais e precisei trabalhar com porcentagens para apresentar no trabalho de mestrado. 